\title{
Evolution of Toilets Worldwide through the Millennia
}

\author{
Georgios P. Antoniou 1,* , Giovanni De Feo ${ }^{2}$, Franz Fardin ${ }^{3}$, Aldo Tamburrino ${ }^{4}$, Saifullah Khan ${ }^{5}$, \\ Fang Tie ${ }^{6}$, Ieva Reklaityte ${ }^{7}$, Eleni Kanetaki ${ }^{8}$, Xiao Yun Zheng ${ }^{9}$, Larry W. Mays ${ }^{10}$ and \\ Andreas N. Angelakis 11,12 \\ 1 Department of Architecture Engineering, National Technical University of Athens, Athens 10682, Greece \\ 2 Department of Industrial Engineering, University of Salerno, via Ponte don Melillo II, Fisciano (SA) 84084, \\ Italy; g.defeo@unisa.it \\ 3 Social Sciences Department, Ladyss (UMR 7533-CNRS) and French Institute of Pondicherry \\ (Umifre 21-CNRS/MAEE), University of Paris, 8, Saint-Denis 93200, France; franz.fardin@gmail.com \\ 4 Department of Civil Engineering, University of Chile, Santiago 8370449, Chile; atamburr@ing.uchile.cl \\ 5 Institutes of Social Sciences and Directorate of Distance Education, Bahaudin Zakariya Universit, Multan, \\ Punjab 60800, Pakistan; Saifullahkhan33@gmail.com \\ 6 Nationality Studies School, University of Yunnan, Kunming 650092, China; 13987103058@163.com \\ 7 Department of Antiquity Studies, Faculty of Philosophy and Letters, University of Saragossa, P. Cerbuna 12, \\ Saragossa 50006, Spain; ievutere@yahoo.es \\ 8 Department of Architecture Engineering, Democritus University of Thrace, Xanthi 67100, Greece; \\ eleni.kanetaki@gmail.com \\ 9 Yunnan Academy of Social Sciences, Kunming 650000, China; zhengxy68@163.com \\ 10 School of Sustainable Engineering and the Built Environment, Arizona State University, Tempe, \\ AZ 85287-5306, USA; mays@asu.edu \\ 11 Institute of Iraklion, National Foundation for Agricultural Research (N.AG.RE.F.), Iraklion 71307, Greece; \\ info@a-angelakis.gr \\ 12 Hellenic Union of Municipal Enterprises for water Supply and Sewerage, Larissa 41222, Greece \\ * Correspondence: antonioug@tee.gr; Tel.: +30-210-729298; Fax: +30-210-7299296
}

Academic Editor: Marc A. Rosen

Received: 18 March 2016; Accepted: 15 June 2016; Published: 13 August 2016

\begin{abstract}
Throughout history, various civilizations developed methodologies for the collection and disposal of human waste. The methodologies throughout the centuries have been characterized by technological peaks on the one hand, and by the disappearance of the technologies and their reappearance on the other. The purpose of this article is to trace the development of sewage collection and transport with an emphasis on toilets in ancient civilizations. Evolution of the major achievements in the scientific fields of sanitation with emphasis on the lavatory (or toilets) technologies through the centuries up to the present are presented. Valuable insights into ancient wastewater technologies and management with their apparent characteristics of durability, adaptability to the environment, and sustainability are provided. Gradual steps improved the engineering results until the establishment of the contemporary toilet system, which provides a combined solution for flushing, odor control, and the sanitation of sewerage. Even though the lack of proper toilet facilities for a great percentage of the present day global population is an embarrassing fact, the worldwide efforts through millennia for the acquisition of a well-engineered toilet were connected to the cultural level of each period.
\end{abstract}

Keywords: latrine; lavatory; wastewater; S-trap; Mesopotamian; Minoan; Greek; Roman; Indus Valley Civilizations; Egyptians; Byzantines; Pre-Columbians

\section{Introduction}

A large amount of research and literature has focused on the historical development of water supply systems and the related hydraulic infrastructure in ancient civilizations; however, there is a lack 
of corresponding information on sanitation and particularly on toilets (or lavatories). This is somewhat surprising since the lack of sanitation affects human development to the same or even greater extent as the lack of clean water [1].

Relevant studies have enabled researchers to understand what facilities were available in different time periods, how design changed over time, how common such sanitation facilities were, and social attitudes to private and communal latrine use. The resulting body of evidence helps us to place into context the efforts made by those in the past to deal with human waste. Besides, it should be emphasized that most of the existing archaeological and written resources throughout history have been focused on urban and elite examples. There is a lack of information on rural practices, despite the probable similarities. On the other hand, the rural examples generally were more impromptu and therefore fewer examples have survived.

The earliest known multiple flushing lavatories attached to a sophisticated sewage system that have so far been identified were located in the ancient cities of Harappa and Mohenjo-Daro in Indus Valley, dating from the mid-3rd millennium BC [2]. Almost every house unit at Harappa, Mohenjo-Daro and Lothal was equipped with a private bath-toilet area with drains to take the dirty water out into a larger drain that emptied into the sewage and drainage system [3,4]. Similar technologies were developed in Minoan Crete and other Greek islands at that time.

In ancient Egypt there were cesspool lavatories located indoors in wealthy houses and temples, and outdoors for other dwellings. Excavations have revealed that underneath a wooden or stone slab seat was a hole leading to a cesspool, which was either filled with sand or emptied every few days onto nearby fields using the human waste as fertilizer [5]. At Abusir, a brass drainpipe running from the upper temple was found along the connecting masonry causeway to the outer temple on the river. At the temple of King Suhura at Abusir stone basins in niches on the walls were used as lavatories, and pipes of beaten copper were used to empty the waste. In addition to these lavatories, a portable lavatory consisting of a wooden stool with a large slot in the middle for use with a pottery vessel beneath was discovered in the tomb of Kha [5]. A recent study has demonstrated human intestinal parasites among the Essene sect at Qumran, near the Dead Sea [6,7]. About 2000 years ago, the Essenes seem to have used a hatchet to bury their feces just below the surface soil. However, a stone lavatory seat with keyhole-shaped defecation opening was recovered from a house in Jerusalem dating to c. 500-700 BC, confirming the presence of such technology by that date [8].

The presence or absence of lavatory sewerage with flushing technology is that which distinguishes the majority of the earlier simple lavatory structures from the more innovative constructions of later antiquity $[9,10]$. Despite advances in engineering, the application of simpler lavatory constructions continued throughout most of antiquity. From the early Minoan era (ca. 3200-2300 BC) issues related to water supply were considered of great importance and were accordingly developed [10]. In the classical antiquity, Greeks and later Romans formed a type of lavatory which survived with limited modifications for more than 1500 years. Besides the flushing flow under the multi seat bench of the lavatory, the common use by several persons was the main feature of that latrine.

During the middle ages, epidemics raged through the majority of European cities, but the medieval world was more conscious of sanitation than other civilizations. The monastic complexes of Medieval Europe present the better lavatory examples of that era, incorporating a common use in most cases. Also, in castles and generally fortifications, there survives a common formation for the lavatory during the Middle Ages, namely, the typical garderobe toilet, usually having a private use (see below Sections 6.2 and 6.3). In the Byzantine period, the combination of several variables, such as the partial continuation of the ancient tradition and practices, the barbaric raids and their results, the social reformation due to the Christianity, etc., had a great influence on the development of lavatory and generally wastewater technologies. In contradiction to the European medieval examples which had often free waste disposal, certain Byzantine regulations made drainage obligatory. Sanitary installations such as toilets were incorporated in most Ottoman religious and secular buildings. Lavatories were situated at a rather remote part of the complex or of the building, and squat toilets were placed adjacent 
to each other, and separated through partitions for privacy. The squat toilets are still found mostly in the eastern world possibly due to anatomically better defecation position and/or possibly related to the Islamic defecation hygiene jurisprudence. Such toilets exist in North Africa, some areas of Europe and South America, due to the Arabic, or generally eastern, influences related also to the Islamic presence in Europe.

The Arab conquest in the 8th c. brought together in the Iberian Peninsula different hygienic manners regarding baths, sewers, and plumbing. The irrigation systems were widely adapted in the rural areas and have persisted until nowadays. The toilet became an indispensable element in an urban house of the Islamic state of Al-Andalus. This circumstance should be considered as a unique one when compared with the hygienic situation in the coetaneous European towns.

At the dawn of the industrial revolution, in the late 18th c., the S-trap pipe provided the most effective means of odor control. In addition, one of the most revolutionary inventions in the sanitary field appeared for the first time, the water closet, and a vision of a new physical urban sanitation system to address concerns about disease transmission from exposure to waste began.

In the 19th c., there were diffuse outbreaks of cholera. Despite the generally accepted concept about cholera which was the miasma theory, in 1854, the British physician John Snow demonstrated that cholera epidemics were waterborne rather than airborne. From the beginning of that century the water closet gained tremendous popularity due to its ability to remove human waste from the house immediately, thus making cesspools no longer necessary. The twentieth century was characterized by the incorporation of several ergonomic features in the toilet technology adjoined by the use of modern material and automation devices. In addition, very often the toilet became one of the main elements where prosperity was presented through luxurious constructions.

In this study, a timeline of historical development of toilets worldwide over the last 5000 years of the human history is discussed. Paradigms of the major civilizations, such as Mesopotamia, Minoan, Indus Valley, Chinese, Egyptian, Pre-Columbian, Classical, Hellenistic, Roman, Medieval Christian and Islamic (the case of Al-Andalus), Ottoman, and modern civilizations are referred to which justify the significance of that technology with respect to world history. A chronological order is followed where possible and convenient for the aim of the study. Emphasis is given to the systems adapted to urban regions and to the places and periods of great achievements. Rapid technological progress in the 20th c. created a disregard for past water technologies that were considered to be far behind the present ones. Even so, there are still a great number of unresolved problems related to sanitation principles and of course to the toilet. In the developing world, such problems have been intensified to an unprecedented degree.

\section{Prehistoric Times}

\subsection{Ancient Mesopotamia (from the Fourth to the Second Millennium BC)}

Mesopotamia is the land between the Euphrates and Tigris rivers and the region bordering them. Roughly, for the purposes of this article, Mesopotamia includes the area of influence of the different cultures developed in that region, thus extending the name to include western Iran, eastern Syria, and southeastern Turkey, area which sometimes is called "Greater Mesopotamia". In this region, agriculture flourished, the first settlements took place, and many key inventions were produced, like the wheel and writing. In Mesopotamian literature, there are scripts about the existence of sewers in their cities [11] (p. 107).

Ancient Mesopotamians managed the waste in two ways: (a) by direct disposal in the ground or under the surface (cesspits) and (b) by transporting it far from the place it was produced using canals or pipes. There is no doubt that ancient Mesopotamians had the technology and the ability to build sewerage pipes to transport the waste from their buildings, as those from the fourth millennium BC from Chogha Mish (settlement in western Iran) and Eshnunna (current Tell Asmar, near Bagdad), shown in Figure $1[12,13]$, and large sewage collectors able to carry the waste outside the city walls, 
like the "main sewer of the royal zone" in the city of Ugarit in northern Syria (Figure 2). Thus, sewage disposal could be achieved in three ways: directly to the gutter or canalization of a street; towards pits located in the city if the house was close to one of them; and for the houses being next to the city walls, directly out of the city by means of canalizations regularly spaced along the ramparts $([14,15])$. Many cities (like Emar in Syria) did not use pipes or canals to conduit the wastewater, they did, however, have the streets built over a layer of permeable soil that could serve this function. Streets of some cities utilized a more elaborated design of permeable roads, which included a layer of soil with high contain of clay in contact with the walls of buildings (examples can be found in the city of Mari in western Syria or Tell Arqa in northern Lebanon) [16]. Certainly, there are cities with both permeable streets and pipe canalizations to transport rain and waste water (e.g., Ugarit and Habuba Kabira).

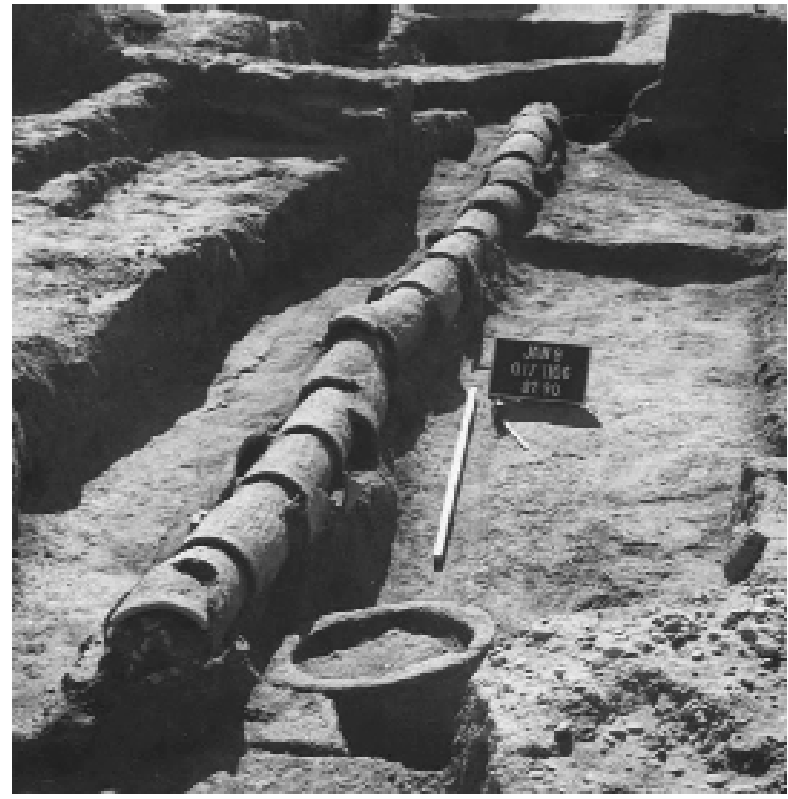

(a)

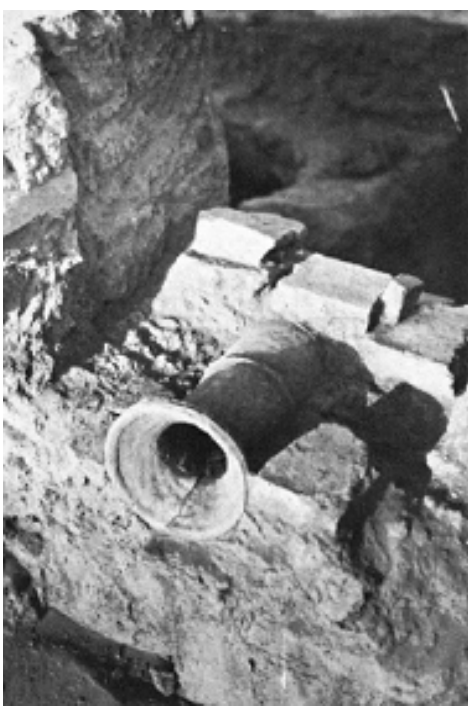

(b)

Figure 1. Pipes from baked clay from the fourth and third millennium BC in: (a) Chogha Mish [12], (Plate 13A) and (b) Eshnunna [13], (Plate 73B). Courtesy of the Oriental Institute of the University of Chicago.

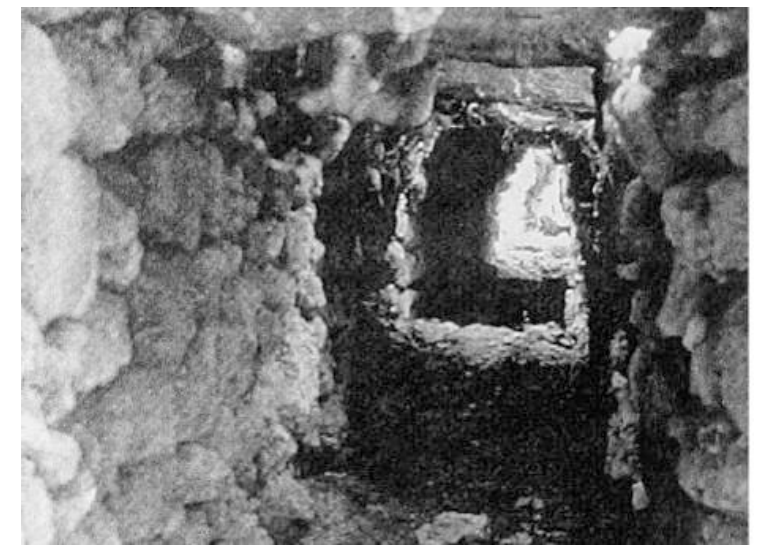

(a)

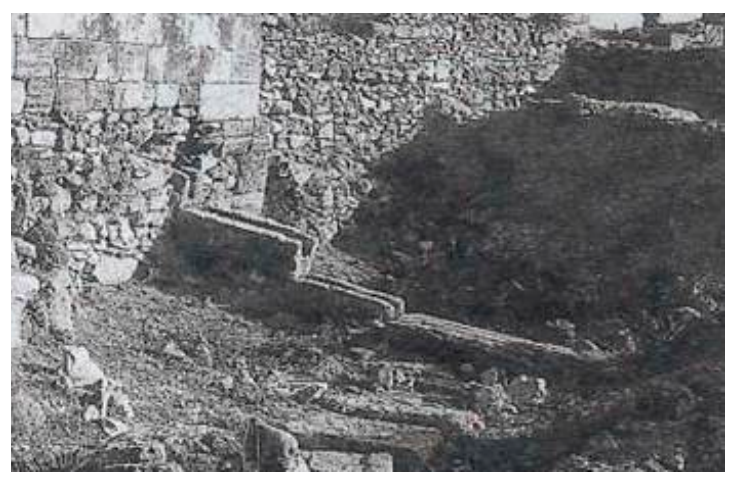

(b)

Figure 2. Sewer in Ugarit: (a) The interior of a section of the underground sewer system in Ugarit and (b) canalization through the walls of a buildings used to discharge wastewater into the great sewer (adapted from [17], Figures 27 and 31, courtesy of Eisenbrauns Inc.). 
Recently, Margueron [16,18] has questioned the idea held for over a century by many archeologists regarding the existence of large sewage collectors in ancient Mesopotamian cities. Margueron argues that transport of solid waste requires conduit slopes and water discharges larger than those usually available in Mesopotamia, and that the net of water conduits uncovered in Mesopotamian cities were built exclusively to manage rainwater. Thus, solid wastes were managed by means of cesspits, which have been found profusely across Mesopotamia. The layout of one of the excavated areas of Ugarit, showing the location of cesspits (black triangles) and water wells (black circles) in a residential area is shown in Figure 3a. Note the proximity of both kinds of facilities, which could lead to contamination of the clean water. Usually, rainwater and wastewater were not mixed and they were transported through separated conduits (except in cities where wastewater was delivered to permeable streets). In several story buildings, rainwater from the terrace was carried by means of pipes or canalizations to the water well, whereas that wastewater was transported from the upper stories to the cesspit. A sketch of these parallel canalizations of a several story house in Ugarit is shown in Figure 3b.
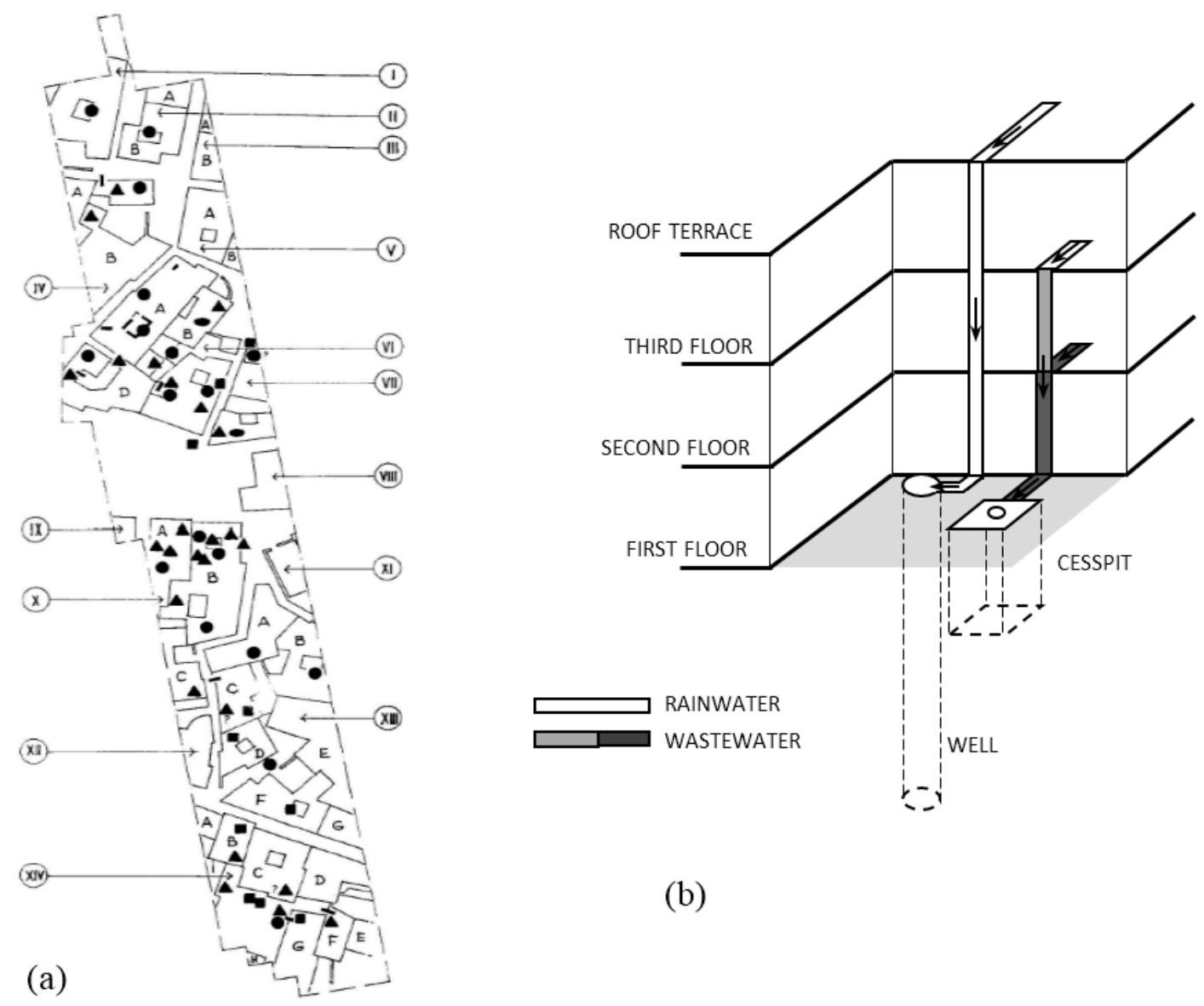

(b)

Figure 3. Residential area of Ugarit: (a) Plant area showing the position of cesspits (black triangles) and wells (black circles) in the houses (from [17], Figure 54 courtesy of Eisenbrauns Inc.) and (b) disposal of rainwater and wastewater in several story buildings (adapted from [16] Figure 97b with permission from Éditions Geuthner).

Bathrooms tend to be found in private houses which are larger than average size, and relatively few built toilets have been securely identified and they usually are located in the least accessible part of the house, as viewed from its main entrance [19] (p. 73). They were also located under the stairs when the building has more than one story [16] (p. 547).

Typically, cesspits were located in an excavation and consisted of cylinder shaped, baked clay pipes. The pipes were stacked on top of each other, with a bell shaped design on the top, which 
connects to the toilet. The pipes have small orifices to facilitate drainage and frequently broken pottery is found around them, enhancing permeability of the surrounding soil. The sections of pipes were about $60 \mathrm{~cm}$ long and $48 \mathrm{~cm}$ in diameter with very thin walls (Figure 4). According to Banks [20] (p. 345), at Adab they reached a depth of 12 to $15 \mathrm{~m}$, and "whatever their length, they reached to the desert sand, and served every purpose of the modem sewer". Other examples of cesspits from the third and second millennium BC presented in the literature are sketched in Figure 5 One of them is from the Sumerian city of Eshnunna (current Tell Asmar, near Bagdad) and it is formed by four pipes with a diameter of about $0.57 \mathrm{~m}$ and $0.32 \mathrm{~m}$ height (Figure $5 \mathrm{a}$ ). The cesspit of the palace of Mari receives the wastes of three different sources (Figure 5b): (a) from the discharge located directly on the top of the pit and (b) from other two nearby sources, conducted by means of clay pipes, joining the cesspit at about 2 and $3 \mathrm{~m}$ below the surface, respectively. The pit is more than $9 \mathrm{~m}$ deep, and each cylindrical pipe has a diameter of about $1.15 \mathrm{~m}$ and $0.62 \mathrm{~m}$ long [16].

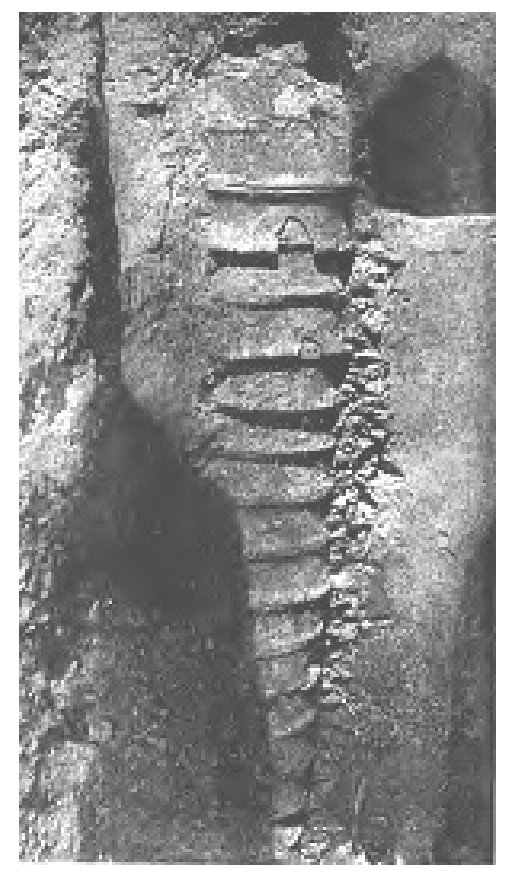

Figure 4. Clay baked pipes of a vertical pit at the city of Adab (second half of third millennium BC) (adapted from [20], p. 346).

Two kinds of toilets have been described in ancient Mesopotamia: toilette à la turque, i.e., a squat toilet, in which the person adopts a squat position, and the seat type toilet. The formation of the squat one has remained almost unchanged for 6000 years. It is the most common type used currently in the Middle East and in many other countries around the world. Besides the human position, there was a different formation for the disposal of the waste. The squat type (Figure 6) usually had a deep pit constructed by cylindrical ceramic drain rings ([21], Figure 3.2). There were also seat type toilets as well as the squat type with foot-stands. The other method for the disposal had a sloped drain leading outside the building most, commonly at the street ([21], Figure 3.3).

One of the toilets from the palace of Mari is shown in Figure 6. These toilets consist of an orifice on the floor, connected to a conduit, canal or directly to the cesspit. Brick supports for the feet are located around the orifice, providing some elevation above the floor. The bricks left a rectangular opening to receive the water spilled in the room whose floor is usually made of baked bricks. The base of the toilet, the room floor and the toilet are usually impermeable white bitumen. Wastes are discharged to the cesspit which is usually located under the evacuation orifice. When the pit is not located directly under the toilet, the orifice is connected to the cesspit by means of a short pipe with a steep slope [18]. 


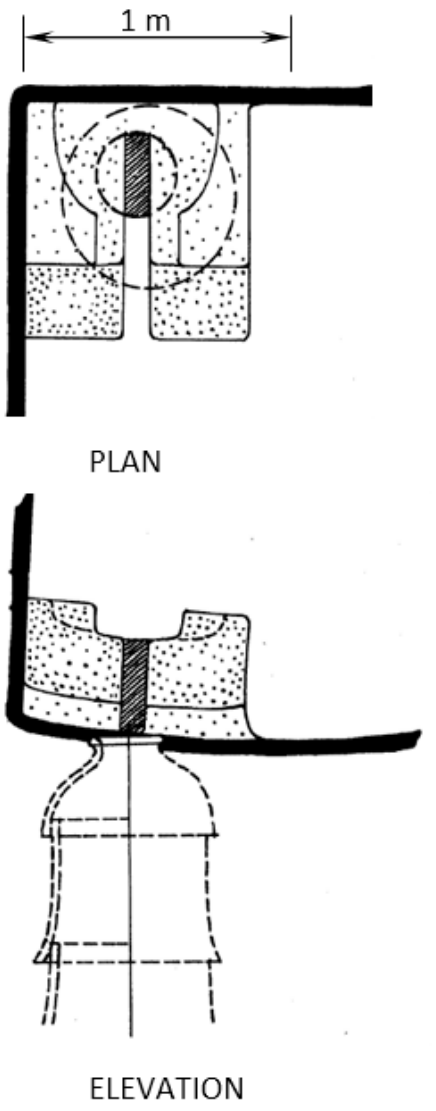

(a)

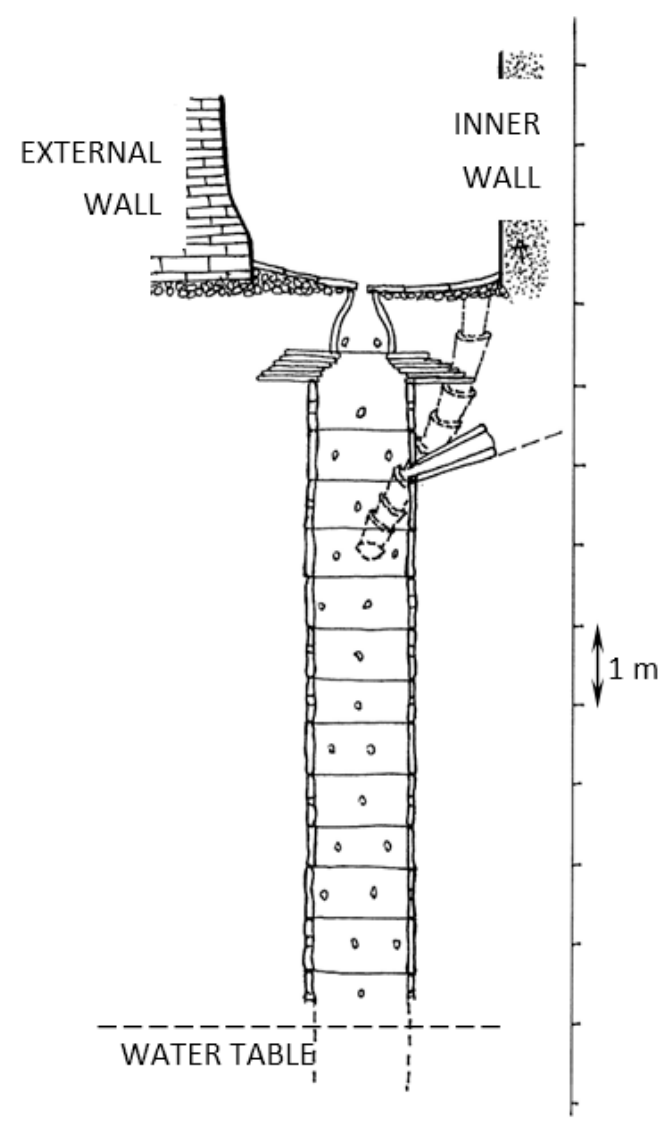

(b)

Figure 5. Sketches of cesspits for disposal of wastewater: (a) Eshunna (Tell Asmar), located at the north-east of Bagdad, third millennium BC (adapted from [13] courtesy of the Oriental Institute of the University of Chicago) and (b) Palace of Mari (south-east of Syria, by the Euphrates river), beginning of second millennium BC (adapted from [16], Figure 461, with permission of Éditions Geuthner). It collected wastewater from three different sources.

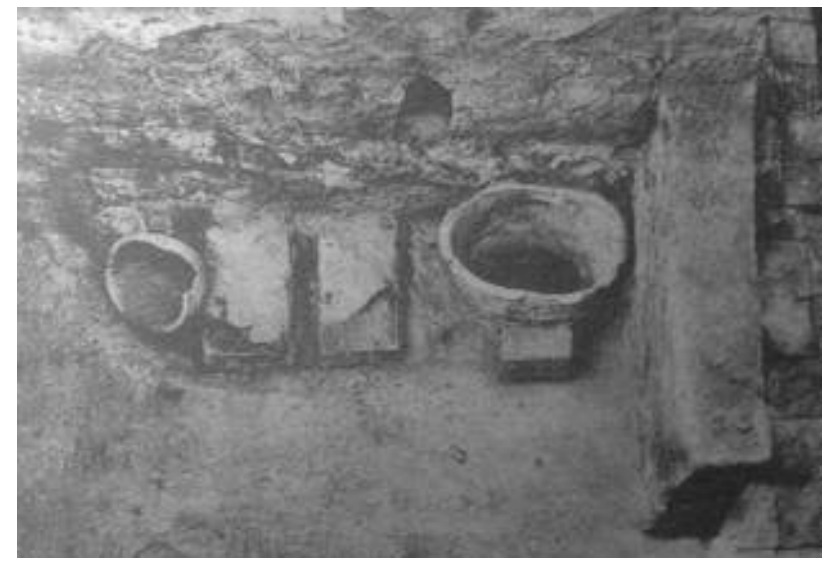

Figure 6. Bathroom with a toilet à la turque, at the palace of Mari, located between the throne room and the kitchen with recipients for water. (adapted from [16], Figure 460, with permission of Éditions Geuthner).

Seat type toilets have been found, for example, in Mari, Eshnunna (Tell Asmar), Girsu (current Tello in southern Iraq), Kish (southern Iraq), Nuzi (near modern Kirkun, in north-eastern Iraq), etc. 
They were built with baked bricks and coated with bitumen, and installed in a room with paved floor. As an example, a toilet from Tell Asmar is shown in Figure 7 with a sketch from Delougaz et al. [13]. The toilet is about $40 \mathrm{~cm}$ high, formed by five courses of $37.5 \times 37.5 \times 7.5 \mathrm{~cm}^{3}$ bricks, with a slot of $10 \mathrm{~cm}$ wide through the middle. The slot connects to the opening of a bell shaped clay pipe (with a mouth of $12 \mathrm{~cm}$ in diameter), and the junction was smoothly calked with bitumen. From a survey made by Margueron [18], it was found that the heights of the toilets reported as seat type in the literature are in the range of 0.2 to $0.6 \mathrm{~m}$, with $0.5 \mathrm{~m}$ the value for about the $50 \%$ of the facilities. Recently, Margueron $[16,18]$ has questioned the commonly accepted view that facilities like that of Figure 7 correspond to toilets. When this type of toilet is not directly over the cesspit, the conduit carrying the waste has a relatively low slope, which is not enough to transport solid wastes. Furthermore, according to Margueron, it is hard to justify two different designs of sanitary facilities coexisting in the same area, because when concerned to the satisfaction of natural needs, a society applies always the same practices, and "the juxtaposition of two different practices for the same society is inconceivable (except in the particular case of colonization)". Finally, on the floor of the rooms where these facilities are located, remainders of tools and artisanal products have been found [16] (p. 551). Thus, Margueron concludes that these set-ups should be considered as devices that were part of the wastewater system of the artisanal industry of the city.

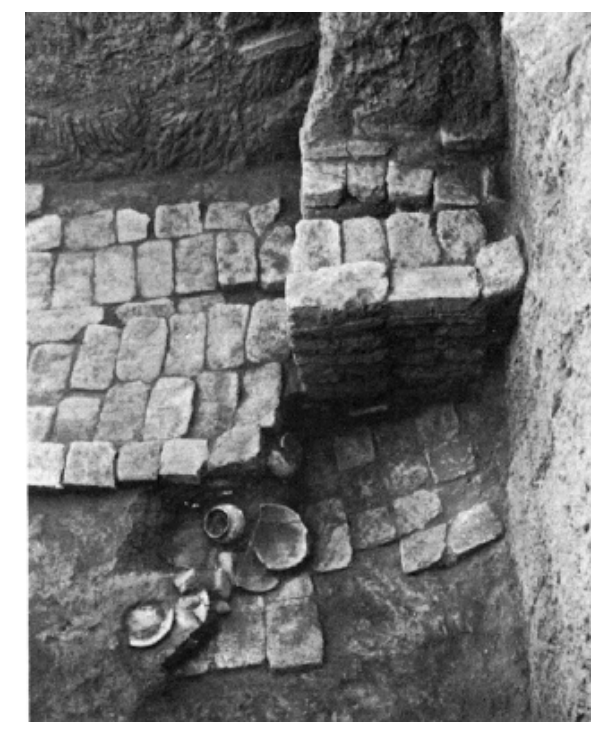

(a)

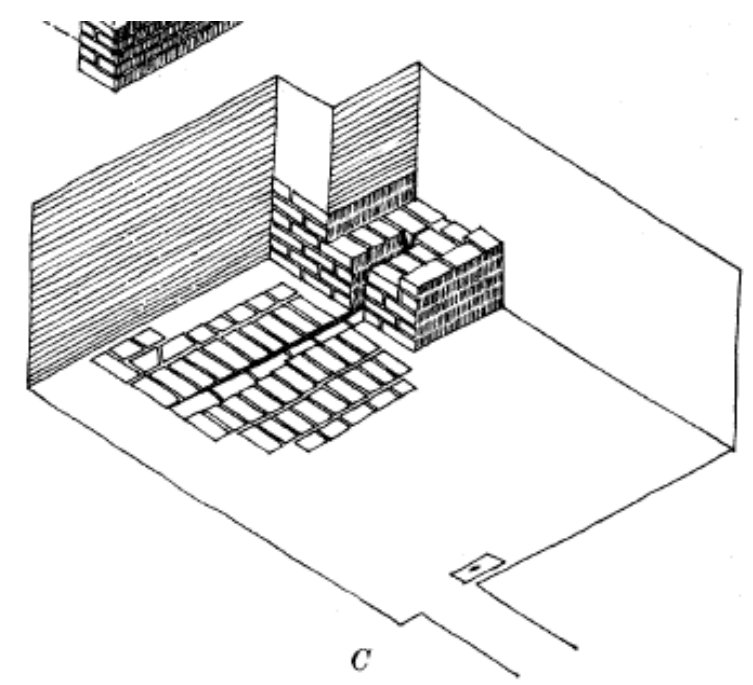

(b)

Figure 7. Seat type toilets at Eshuna (Tell Asmar): (a) Photo and (b) Sketch (adapted from [13], Plates 76 and 42) Courtesy of the Oriental Institute of the University of Chicago.

\subsection{Minoan Civilization (ca. 3200-1100 BC)}

The Minoan civilization, ca. 3000 to 1350 BC, flourished mainly on the island of Crete, Greece, which is an isolated position at the Mediterranean Sea. Crete has a variable climate and geography and a very low water availability. Knowledge of "hydraulics" was quite evolved from very early times of Minoans on Crete. Knossos, the capital city, had a central courtyard with baths that were filled and emptied using terra-cotta pipes. This piping system is similar to techniques used today. Until Roman times, Minoan plumbing and drainage were the most developed in what was then the Western World [22]. Also, the Minoans had a highly developed waste management system since ca. $1500-1700 \mathrm{BC}$. They had very advanced plumbing and designed places to dispose of organic wastes. In addition, an elaborate system of stone drains is constructed for sewage and storm water drainage (Figure 8). They had large sewers built of stone. Some of the sewers were large enough for people to walk through [23]. 


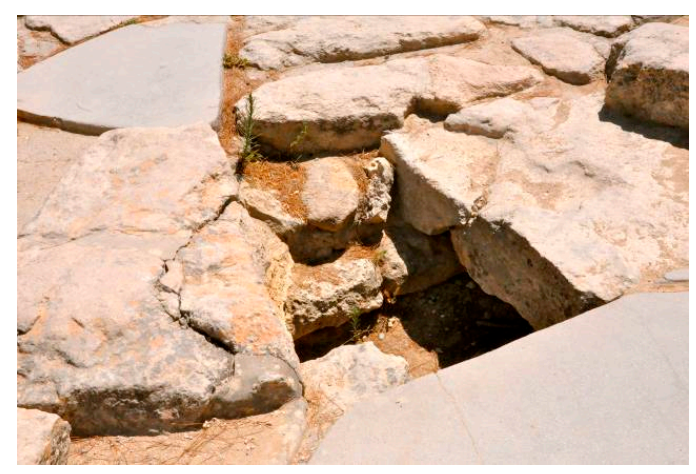

Figure 8. Evidence of the Minoan engineering. On top a channel for regular water, underneath was a channel for toilets waste water (not visible in the photo, A. Angelakis).

No public toilets were known in Minoan Crete, while in a number of houses the lavatory was located in the private living rooms (e.g., Knossos, Phaistos, Tylissos, Malia, and Gournia). In most cases the evidence for the identification of a toilet was from the existence of a sewer at the floor level passing through the exterior wall and connecting with the outside central sewerage and drainage system. However, in some homes there are also traces of some sort of provision for a stone or wooden seat [24].

One of the most interesting rooms in the ground floor in the residential quarter of the Knossos palace was identified as a toilet. Remains of a clay tube were found just outside the door of the room. It is thought that water was poured through a hole in the floor immediately outside the toilet door, while an under-floor channel linked the hole with the vertical clay pipe under the lavatory seat [25]. The toilet consisted of a wooden seat about $57 \mathrm{~cm}$ from the ground with an earthenware "pan" and a rooftop reservoir as a source of water [26]. The toilet could thus be flushed even during a rainless summer, either by an attendant outside the lavatory or by the user. The toilet in the residential quarter of the Palace of Minos in Knossos [22] is probably the earliest flush lavatory in history (Figure 9).

At certain times of the year the drains in the palace of Minos may have been adequately flushed through by the rainfall that fell into the light-wells, but in general it was supposed that water was poured into the toilets to flush them. It was also observed that there was sufficient space at the end of the seat at Queen's Hall lavatory in Knossos for a large pitcher [27]. The toilet is similar in function to that of the so-called Queen's Hall, those found in the Phaistos and Malia palaces as well as in some of Minoans cities and houses [24].
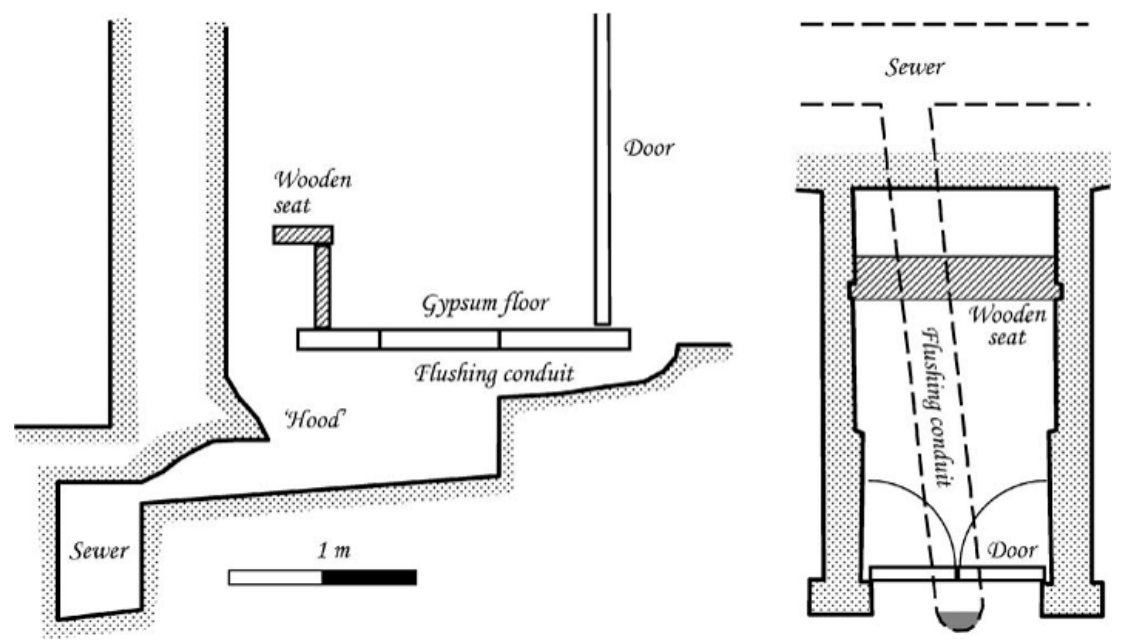

Figure 9. Cont. 


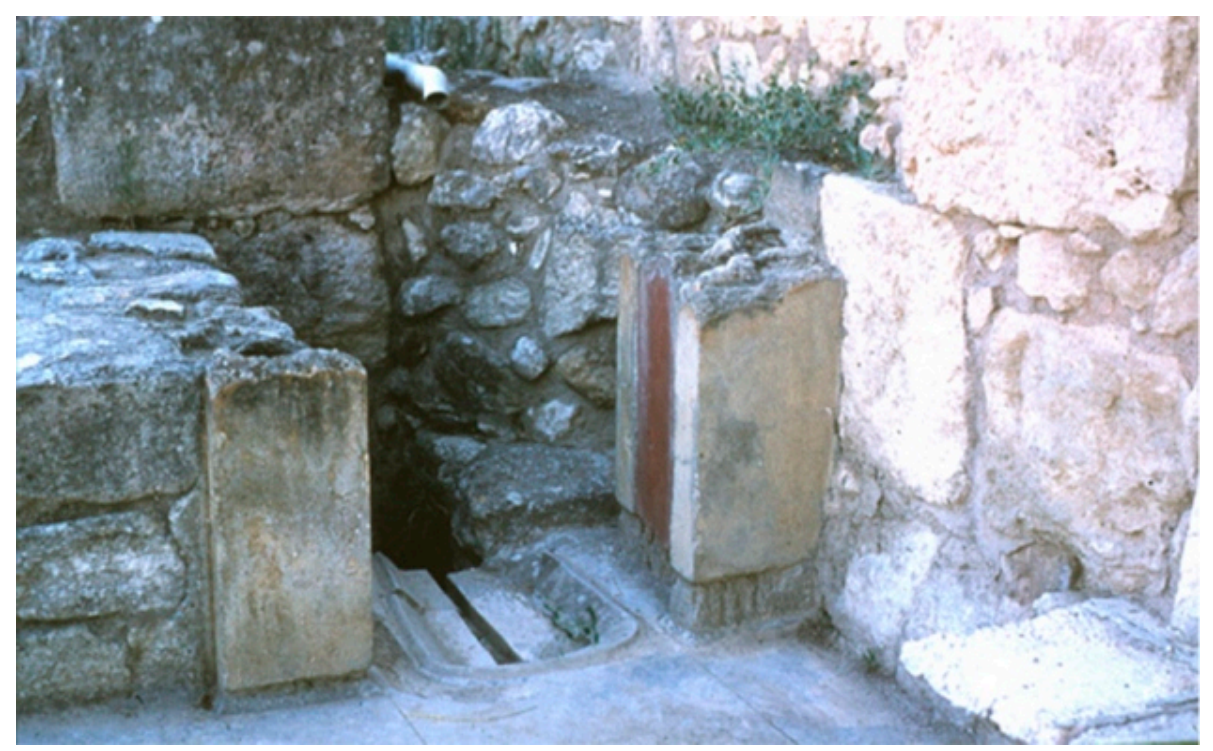

Figure 9. Section and plan of ground-floor toilet in the residential quarter of palace of Minos (top) (adapted from [22]) and general view (bottom) [28].

Another toilet was discovered in one of the houses near the palace at Malia, known as Da. It contained a seat in nearly perfect condition, since it was made out of stone, not of wood like the seat at the palace of Minos in Knossos [29]. This stone seat was $68.50 \mathrm{~cm}$ long by $45.50 \mathrm{~cm}$ wide front to back, and its surface was $34-38 \mathrm{~cm}$ above the floor (Figure 10a,b). It was built directly against an outside wall through which a large sewer passed like that in Knossos, the structure was evidently intended for use as a seat rather than a stand [24]. Thus, it resembles the "Egyptian" toilet mostly than the so-called "Turkish" type found in the palaces at Mari in Syria and Alalakh in Turkey [22]. However, there is a substantial difference between those toilets and the Minoan, due to their flushing processes and their connections to the sewers. The toilet at the palace in Knossos mentioned before [22], may well be the earliest flush toilet world widely identified to date. A similar toilet has been discovered in the west side of the so-called Queen's Apartment at Phaistos. It was also connected to the sewage and drainage system of the palace. Another toilet connected to a sewer was discovered in House $\mathrm{C}$ at Tylissos [30]. In addition, most Minoan toilets were located near or next to the bathrooms.

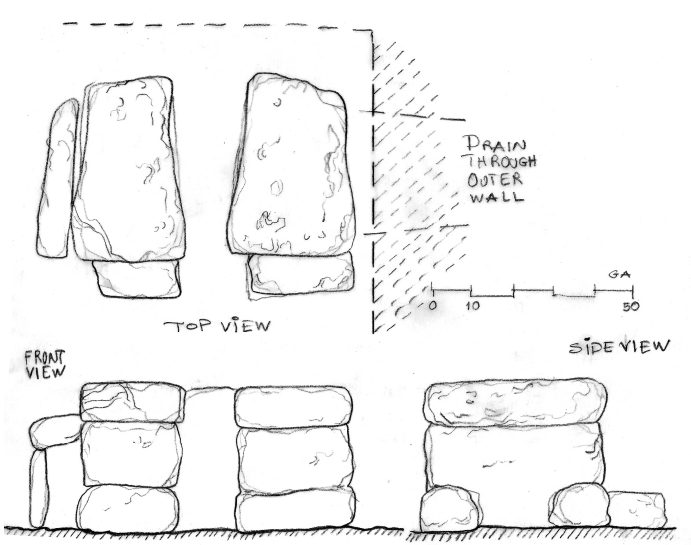

(a)

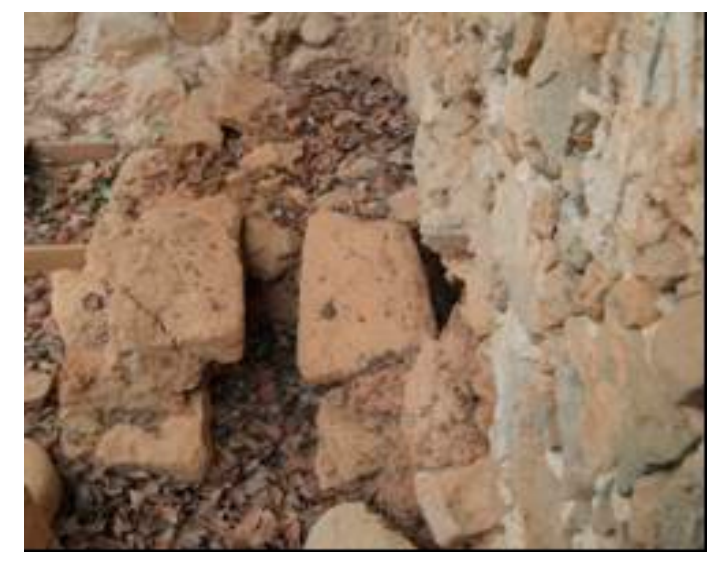

(b)

Figure 10. Toilet in the House Da, Malia: (a) Dimensions of the toilet (G. Antoniou inspired after [29]) and (b) a recent photo (A.N. Angelakis). 
In addition to the toilets with flushing systems operated by pouring water into a conduit which discovered in Minoan Crete [22], a toilet of such an installation was found in the island of Thera (Santorini) in the Cyclades [31]. This is the best-preserved example belonging to ca. $1550 \mathrm{BC}$, in the Bronze Age settlement of Akrotiri, which shares the same cultural context with that of Crete [32].

\subsection{Indus Valley Civilization (ca. 3200-1900 BC)}

Indus valley civilization had a proper town planning with well laid out streets, separate living quarters, flat-roofed brick houses, efficient drainage system, ventilation and toilet system. Harappa town planning has stunned the archaeologists worldwide [33] (Figure 11), [4]. It has become a landmark for the contemporary civilization when technological advancements have been made which is helping to achieve great heights. It has inspired the contemporary generation. The concept of bathing pools and granaries gives a glimpse of the modern day swimming pools and storehouses where grains can be stored. It was a proper furnished city. This facilitated the Harappa dwellers to live a luxurious life with proper sanitation and regulation $[34,35]$.

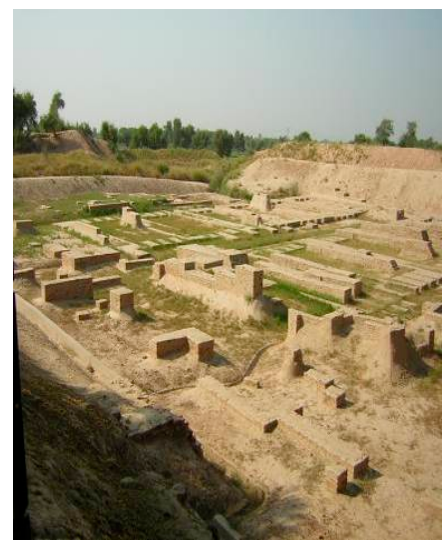

(a)

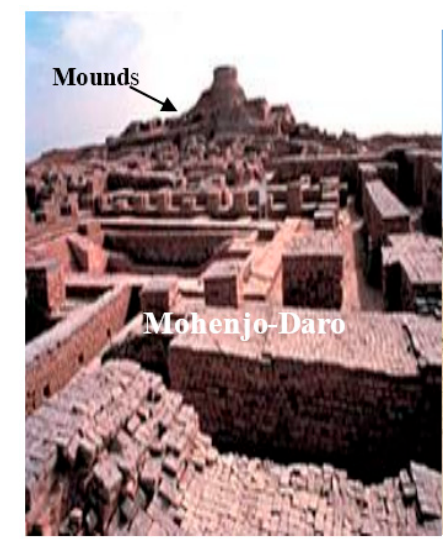

(b)

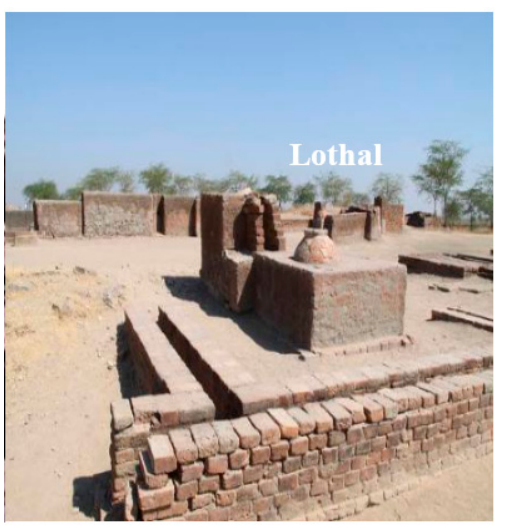

(c)

Figure 11. Town planning of Indus valley civilization at: (a) Harappa; (b) Mohenjo-Daro; and (c) Lothal (adapted by [4]).

Indus civilizations during the Bronze Age (ca. 3300-1300 BC (with mature period of ca. 2600-1900 BC) developed in the northwestern region (e.g., Mohenjo-Daro, Harappa, and Lothal) of the Indian subcontinent. According to De Feo et al. [1], Mohenjo-Daro, considered as one of the capitals of the Indus valley culture, can be considered as the most sophisticated ancient places with wastewater management. Indeed, almost every habitation of this urban site had its own bathroom including a lavatory and was connected to the sewerage and drainage system [35]. The three main aspects of domestic wastewater management included the bathroom, the lavatories, and the sewage and drainage system.

In each society from time to time the administration felt the need to provide public toilet facilities to those who could not afford to have individual toilets. The public toilets have a long history in a number of countries and most of these were constructed and managed by municipalities. There was, however, all around disgust with their poor maintenance, vandalism and lack of basic facilities [27]. In the absence of proper toilet facilities, people had to defecate and urinate wherever they could. Defecating on roads, open spaces, or in rivers was very common

The third millennium BC was the Age of Cleanliness. Toilets and sewers were invented in several parts of the world, and Mohenjo-Daro, ca. 2800 BC, had some of the most advanced, with lavatories built into the outer walls of houses. These were primitive "Western-style" toilets made from bricks with wooden seats on top. They had vertical chutes, through which waste fell into street drains or cesspits [27]. 
The toilets at Mohenjo-Daro were only used by the affluent classes. Most people would have squatted over old pots set into the ground or used open pits (Figure 12). The people of the Indus valley civilization in Pakistan and north-western India had primitive water-cleaning toilets that used flowing water in each house that were linked with drains covered with burnt clay bricks. The flowing water removed the human wastes [36].

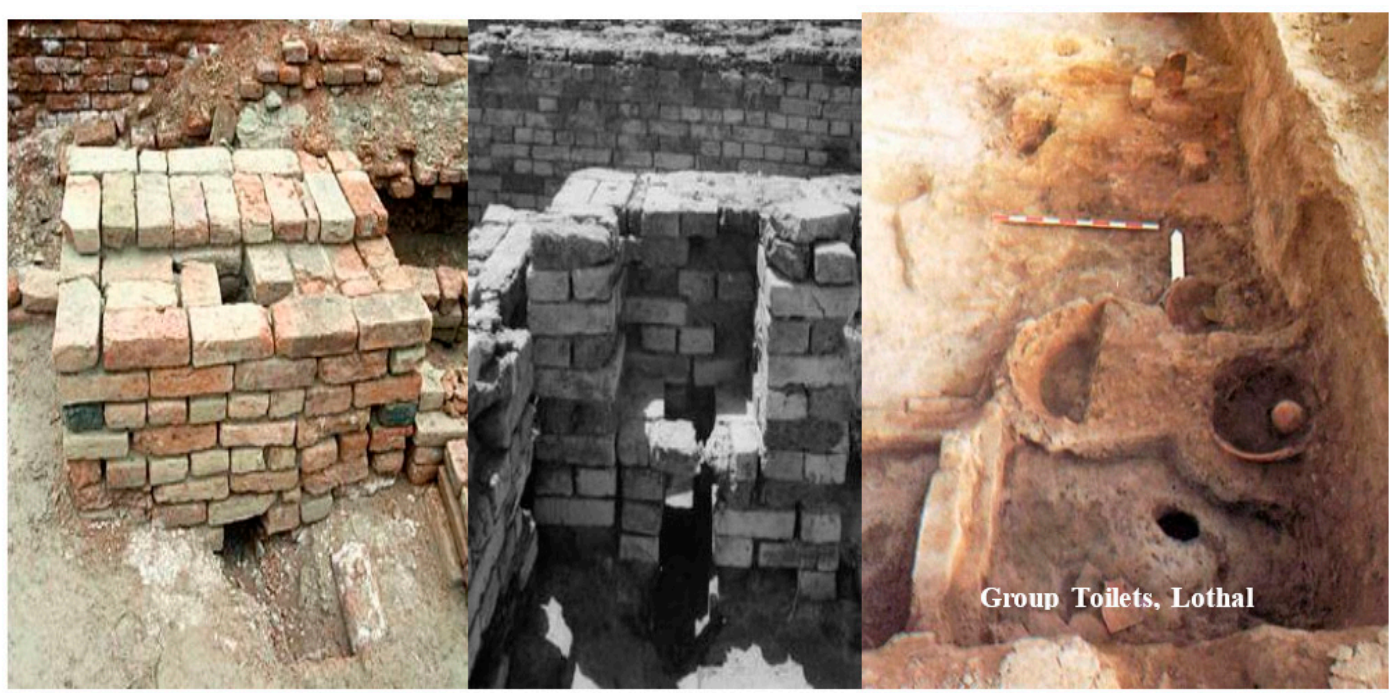

Figure 12. Public toilets, Open toilet and house hold toilet in Indus valley civilization (adapted from [4]).

The Indus valley civilizations used flushing toilets similar to that of Minoan civilization. The cities of Harappa and Mohenjo-Daro had a flush toilet in almost every house, attached to a sophisticated sewage system very similar to those reported in Knossos and Akrotiri of the ancient Minoan civilization from the 2nd millennium BC [33].

Toilets would have been an essential feature in Mohenjo-Daro, but the early excavators identified most toilets as post-cremation burial urns or sump pots. This brick structure had a hole in the top that was connected to a small drain leading out of the base into a rectangular basin (not reconstructed). Early excavators suggested that structure with a hole and drain located are thought to have been toilets (Figure 12). For human urination, they may have used a hole in the ground at open places that connected to nearby drain. The toilets of Indus valley civilization were different than the Roman and Greek Civilizations. This difference is the main evidence of the cultural difference between them [36]. The Indus valley civilization in Pakistan has the concept of toilet and latrine and a well-established waste system at that time, as shown in (Figure 13).

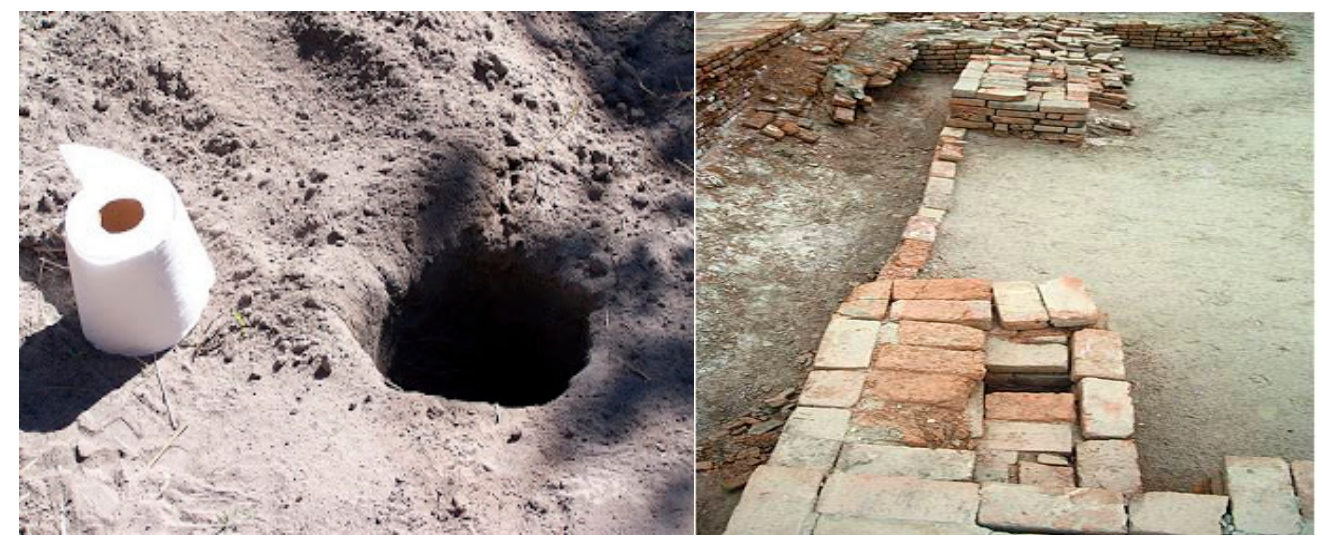

Figure 13. Indus valley civilization open toilets Commodes, (adapted from [4]). 
Finally, by about $1700 \mathrm{BC}$, the Indus valley civilization was on the verge of decline. Town planning is one of the most outstanding and remarkable features of the civilization. They have well planned drainage and sanitation systems, dockyards, and hydraulic engineering. The houses had their own wells, bathroom, and household toilet. They also have the concept of providing public toilet facilities to those who could not afford to have individual toilets. Almost every house had a bathroom and toilet, usually a fine sawn burnt brick pavement, often with a surrounding curb. The house drains start from the bathrooms and toilets of the houses and join up to the main sewer in the street.

\subsection{Mycenaean Kingdoms (ca. 1900-1100 BC)}

Mycenaean represents the first advanced civilization in mainland Greece, with its palatial states, urban organization, works of art and writing system. Mycenaean and Minoan civilizations shared several similarities in terms of water and waste water technologies. Due to the inability for a precise dating of the finds of these periods it is not easy to determine if these technologies emerged simultaneously or the Mycenaeans influenced by Minoas after their invasion in Crete. Nevertheless, both had baths that fitted the human body quite ergonomically, but most traces testify that they did not have individual bathtubs like the Minoans [24]. Sewer ducts and drainpipes for vertical water transfer also existed in Mycenean buildings. However, it seems that in Mycenaean culture there was no running water in lavatories [24]. On the other hand, in Tyrins, a characteristic Mycenaean fortified settlement, there were ducts leading out of enclosures which are considered either as toilet duct or sewers [24].

\section{Pre-Columbian America (ca. 2000 BC-1500 AD)}

In spite of the highly developed civilizations that flourished in pre-Columbian America, there is no record or evidence of the use of toilets. However, the recent discovering and description of a pressurized conduit by French and Duffy [37] in Palenque, from the Classic Maya period (ca. 250-600 AD), does not rule out the technical knowledge of the Mayans and their ability to build toilets. The Maya had to deal mostly with seasonal lack of water and they needed to build storage reservoirs, but the people of Palenque had to cope with an excess of water on a limited terrain with steep slopes. Several technical solutions were applied, i.e., expanding the size of their plazas by $23 \%$ [37]. They had the ability to design and construct structures as pressurised conduits (aqueducts) and fountains. French [38] indicates that there were what appear to be two indoor toilets in the Palenque palace building, suggested by the shape of the features and their drain system, but there is no direct evidence of such use and more studies and analysis are needed. He also states that he is "not aware of any other toilet at any pre-Columbian site".

\section{The Far East Technologies}

\subsection{Early Chinese Dynasties and Empires (ca. 770 BC-220AD)}

The earliest records concerning the construction of toilets were made during the Warring States period (475-221 BC) [39]. Literature of the Warring States Period recorded a kind of toilet which was built with high walls to ensure privacy. During the Han dynasty (ca. 202 BC-220 AD), the building of a toilet was quite popular. At that time, toilets were usually built beside a pigsty (Figure 14); and probably for the purpose of using the dross of humans as the feed for pigs, or mixing the ordure of human and pigs as the fertilizer [40]. According to a burial object of the Han dynasty which is a model of a house found in the Jiangsu Province, toilets were often built beside a pigsty, ceiled, and built with latrines. Thus, latrines were usually connected to the pigsty. Archives in the palace of Liu Dan, the King of Yanci, recorded that pigs rushed out of the toilet and destroyed the large public kitchen. Hence, this showed that toilets of nobilities were also built beside a pigsty [41]. 


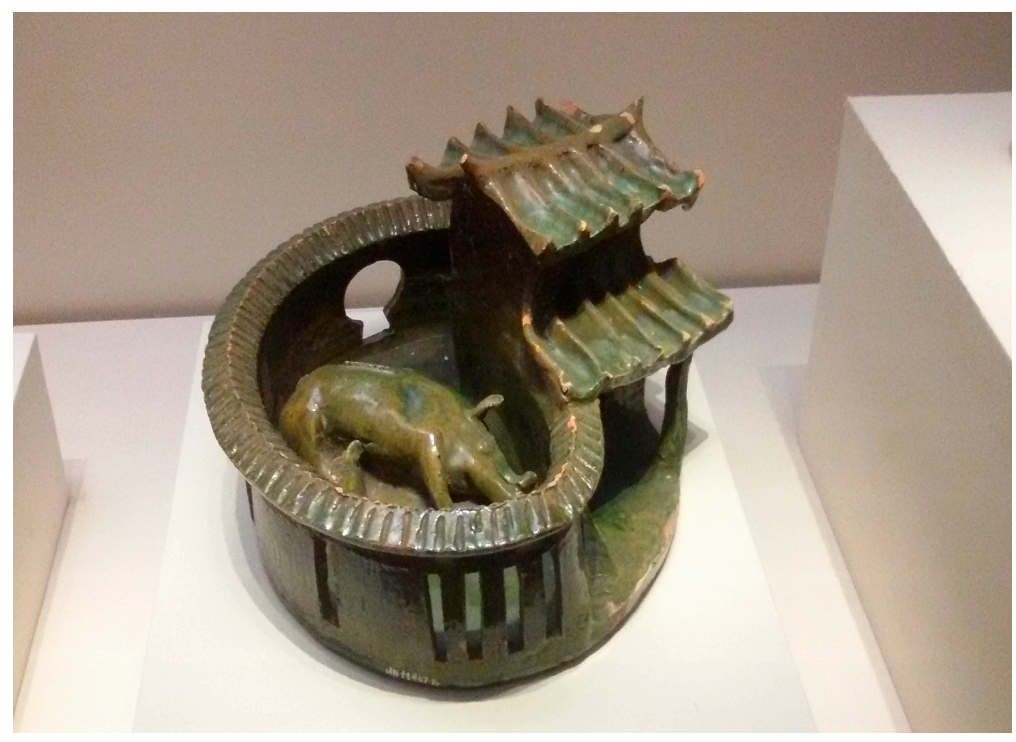

Figure 14. Pigsty toilet model, Eastern Han dynasty 25-220 AD, China National Museum, Beijing, China (with permission of Xiao Yun Zheng).

\subsection{Japanese Examples}

Examples from the Japanese antiquity that were found in archaeological excavations present a variety of lavatory types. Simple and more articulated technical solutions combine very often a continuous flow as a flushing device. The simplest types recorded are those of a simple open pit providing an impromptu squat formation ([42], Figure 15a). As it can be traced from the existing examples, the squat type of toilet was rather predominant in Japan. The continuing flow toilet at Heijo-Kyo as it is represented [43] uses a water duct bypass to provide a kind of relevant flushing. The waste ended at the main duct afterwards. It seems that this formation was a kind of reuse of wastewater flow for the uses of the toilet. Similar formations have been identified during 4 th c. BC in Amorgos, Greece [44], pp. 82-83).

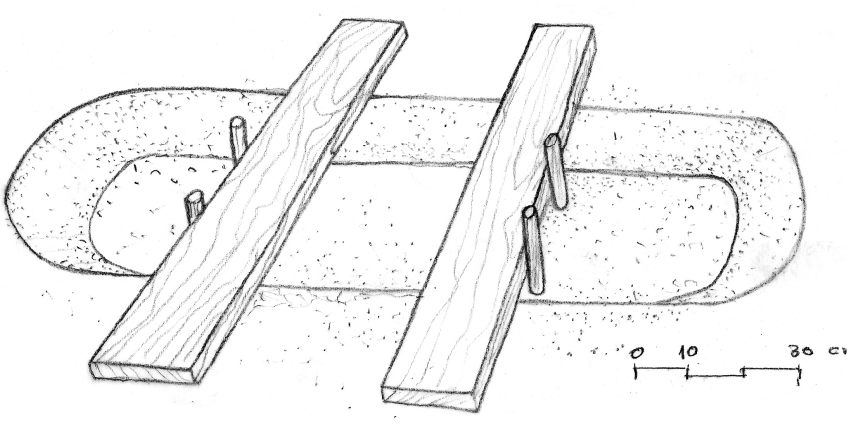

(a)

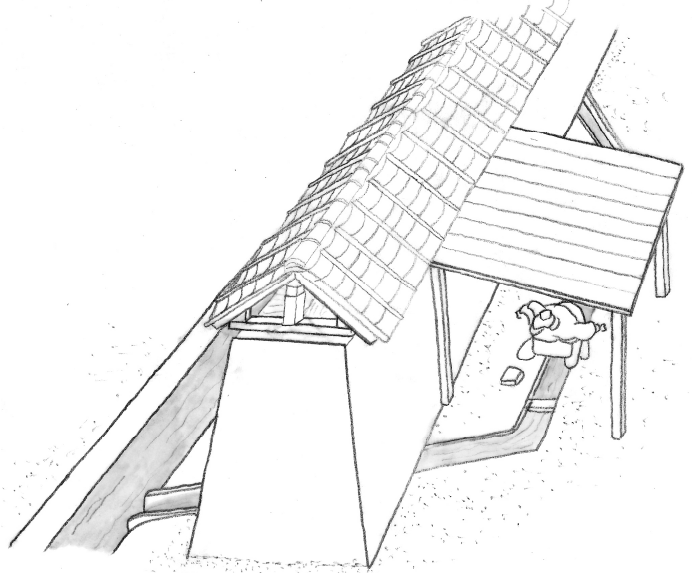

(b)

Figure 15. (a) Fujiwara palace toilet and (b) Heijo-Kyo open air toilet (G. Antoniou, inspired by [43]).

As far as it is traceable from the existing examples there was either limited or sufficient privacy at the Japanese toilets. A wall and a simple shed at Heijo-Kyo (Figure 15b) provided limited privacy, but light walls in Akita Castle (Figure 16) reassured totally privacy for each squat toilet of the row. 


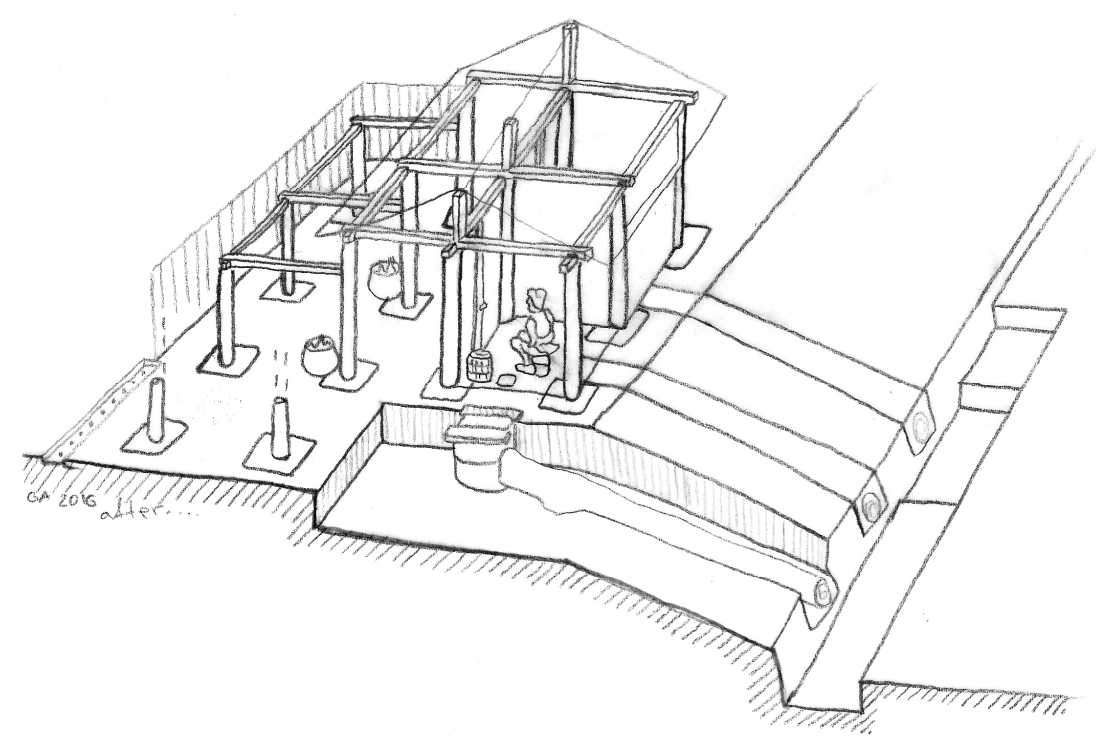

Figure 16. Toilet complex at Akita Castle (G. Antoniou, inspired by [43]).

\section{Antiquity of the Mediterranean Region}

\subsection{The Classical Greek and Hellenistic Periods (5th c.-1st c. BC)}

Because of the extremely limited remains from the Geometric and Archaic periods (relatively 10th c. -8 th c. and 7th-6th c. BC), the sanitation techniques is unknown. Possibly some built examples resembling the preexisting Mycenaean era formations [45] were continued. Also, clay pots and vessels - such as the amides and skoramides - would have been common features during that era, as it can be concluded from some 6th c. finds (Figure 17) and earlier surviving examples of the 5th c. BC.

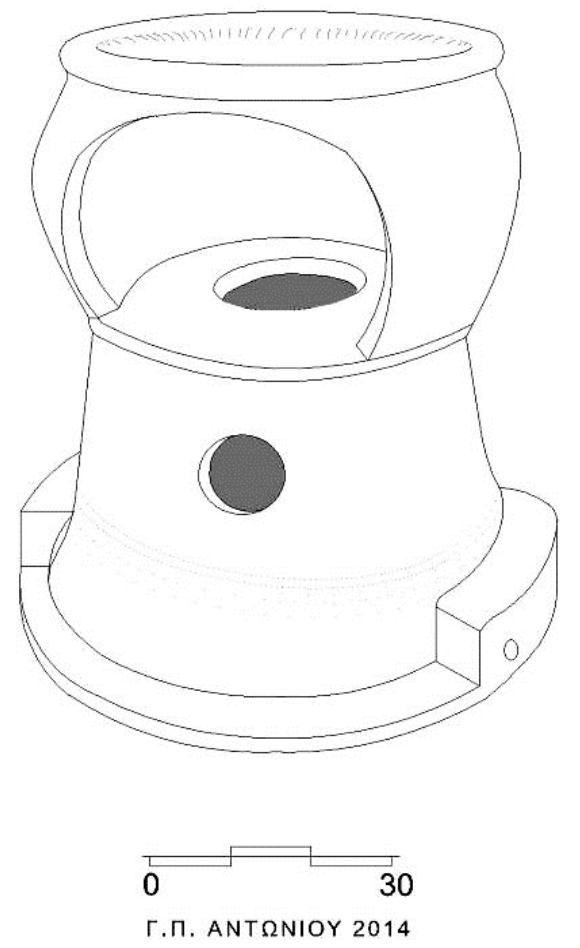

Figure 17. Child's seat and chamber pot, early 6th c. BC, Agora Museum Athens, Greece (sketch by G. Antoniou). 
Even though latrines were mentioned in many literal references no public or private lavatories dated in the Classical period (4th-5th c. BC) have been found. Despite the absence of flushing toilets in excavations from this time period, cesspits ( $\kappa o \pi \rho \omega v-k o p r o n)$ have been found during the excavations by the American School of Classical Studies in houses of this period in Athens (specifically north of Areios Pagos). Similarly, on Rhodes, small rectangular constructions under the streets, just outside the houses are believed to be koprons [46].

The comedies of Aristophanes are the main ancient sources about the terminology of the sanitary

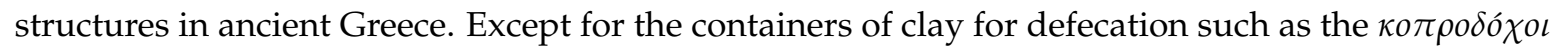
(koprodochoi) (amides or skoramides from Athens, see also [47]), well known from written sources, the archaeological finds of small cesspits and sewage ducts dated in the ca. 5th c. BC could be related to traces of sanitary and purgatory structures found in Olynthus [48], a city destroyed by King Philipp II in 348 BC. Not only have small sewage ducts made of clay or lead been found, but also well-formed sanitary clay vessels. All these clay utensils can be easily dated to the ca. 5th c. BC and are characterized by the efforts for achievement of anatomical shapes. In these seats, the absence of a base combined with the form of the lower edge (see Figure 18) suggests that they were either used over cesspits or along with some other mechanism for the collection and drainage of excrement. It is evident that at that time the lavatory still had a private use (apochorisis, apopatos, afedron). The ancient terms mostly refer to a private type of use and the main term derives from the apochorisis (withdrawal) [9]. The typical ancient Greek lavatory on the other hand is characterized by the use of more than one person at the same time (see Figure 19). The design of a typical lavatory in ancient Greece had been completed by the ca. 4 th $\mathrm{c}$. BC, and had incorporated all the preexisting design features of that type. Some documentation for similar installations in the Minoan and the Mycenaean period has already been discussed above.
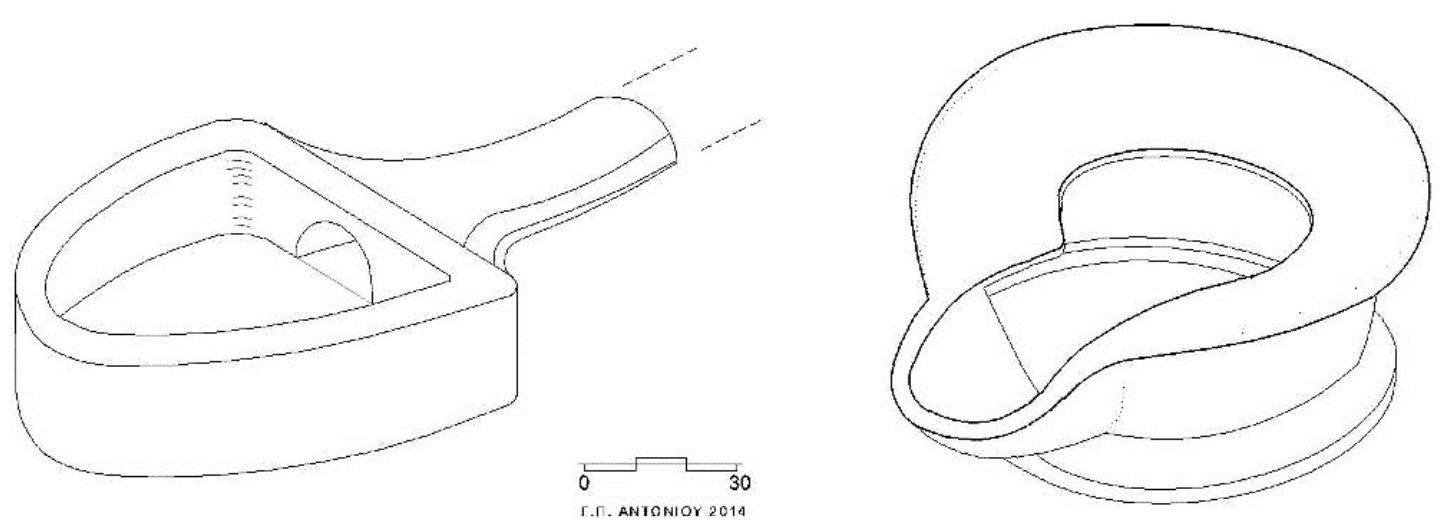

Figure 18. Axonometric sketches of clay defecation and toilet seat vessels, Olynthos (G. Antoniou sketched inspired by [48]).

The well-formed type of the ancient Greek lavatory was characterized by some typical features which remained more or less the same for the lifetime of the structure. These features were the input water conduit, the flushing duct below the floor level, the bench-type seats with the keyhole-shaped defecation openings, the front covers of the bench-type seats and the necessary sewage duct, usually by the outer wall (see Figure 19). 


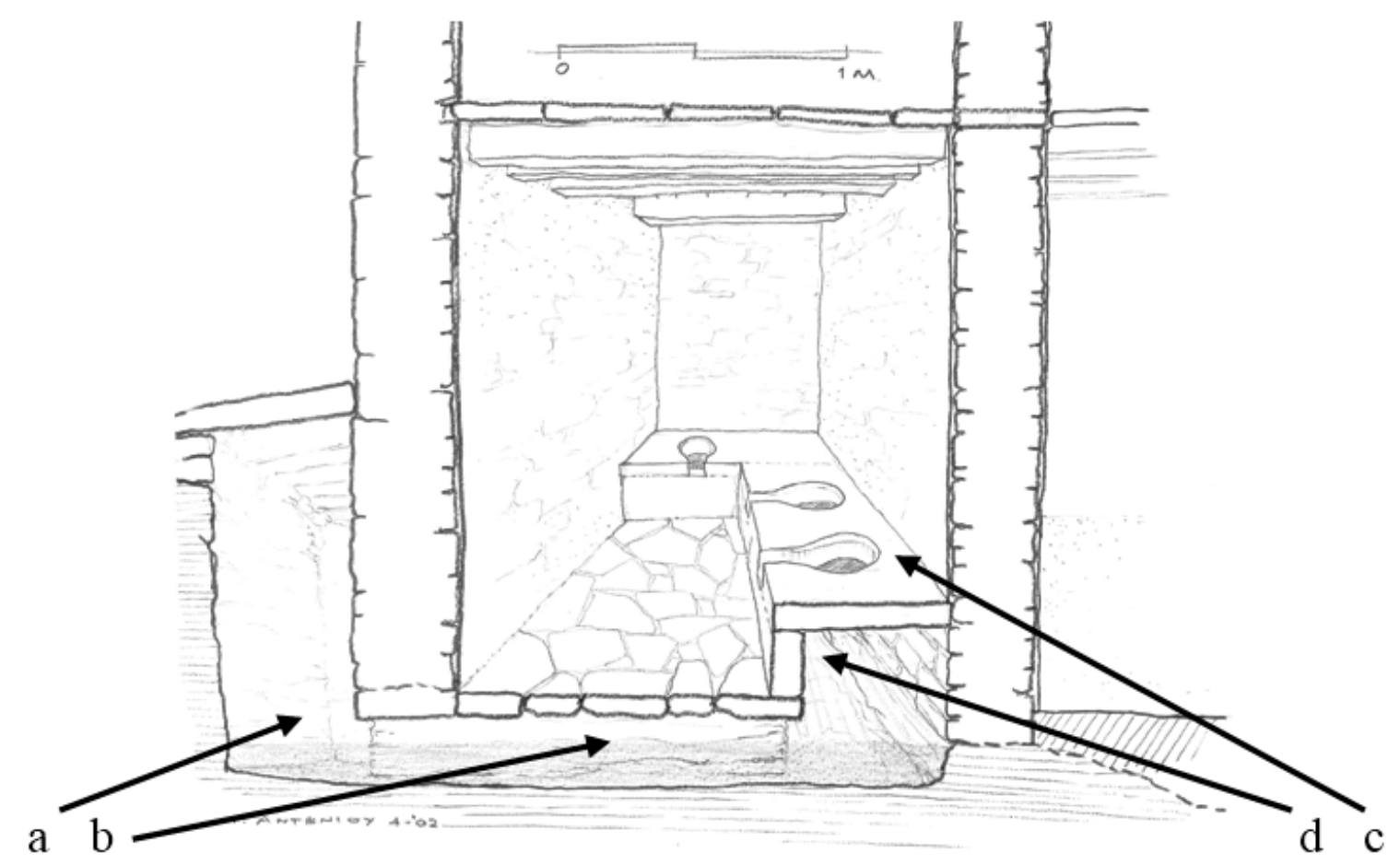

Figure 19. Restored view of the lavatory at Ithidiki's residence on Amorgos: (a) input water conduit; (b) flushing duct below the floor level; (c) bench-type seats with the keyhole-shaped defecation openings; (d) front covers of the bench-type seats; and (e) sewage duct. Notice (e) is located at the back and it is not visible (courtesy of G. Antoniou).

Beside these, there were also other secondary constructions as the central shallow tank for cleaning the sponghia (out of sponge) the toilet paper of that period, the urine sewage conduit, small sedimentation tanks, etc. The seats' supporting presents interesting differentiation and typology. Four types can be distinguished. All of them are cantilevered, mostly covered except the later type in Philippoi [49] and Efessos (see Figure 20c). More specifically, these are:

(a) Cantilevered stone slab protruding out of the wall.

(b) Freely supported slab over stone beams, cantilevered or not.

(c) Similar to the previous type where the stone joists protrude out the vertical plates and have been formed as neck moldings of benches and exedras.

(d) Type where the freely supported seat slab is also supported by stone cantilever beams which were shorter and less wide than the seat.

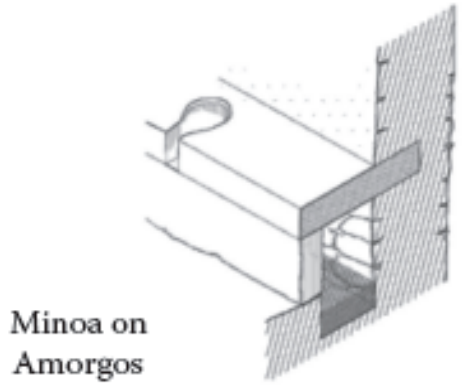

(a)

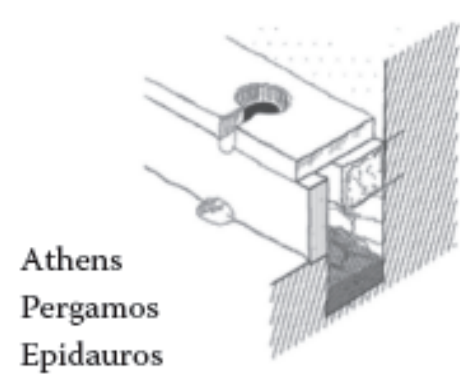

(b)

Figure 20. Cont. 


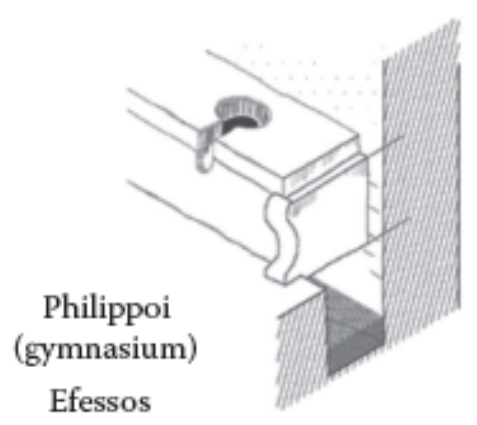

(c)

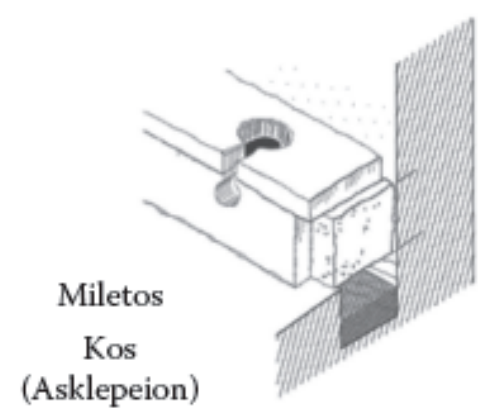

(d)

Figure 20. Formation and types of lavatory's seats supporting (G. Antoniou).

The element of the keyhole-shaped opening became a feature of the lavatory with some ornamental forms. Despite that, it is obvious that the functionality was always very important. There is also some evidence that the covers for the openings were made out of clay. The seats in small domestic lavatories were just wooden benches, probably with similarly shaped openings. The main difference between private and public toilets was their size and the number of users. On the other hand, the method for the water supply differs sometimes, since the domestic lavatories require less water for the flushing. The public ones were usually supplied with running water, reused or not [43] (pp. 82-83). The sewage ducts of the city usually ran along the streets or beside the buildings. Sometimes in small residences, there were no sewage lines and the waste was placed outside the house (i.e., in Dystos [50]). Many latrines dated to the ca. 2nd c. BC have been preserved in residences (Delos, Thira, Amorgos, Dystos, Kassopi, and Erythrai) and in public buildings (especially Gymnasiums and Palestrae). The significance of Delos (see Figure 21) for the evolution of the typical layout of the ancient Greek lavatory is important [9], and the need for a more detailed historical investigation and presentation was recently examined [51]. Lavatory capacity can be classified according to the number of the toilet seats, which correspond to the maximal number of users at any one time:

(a) The very small domestic lavatories used by two or three people of the house (e.g., in ancient Dystos, Greece, [9], Figure 21).

(b) Moderate-sized domestic lavatories with more than four defecation seats.

(c) Small public lavatories with evidence for at least four users at a time (e.g., Gymnasium of Minoa, [9] and in Palestrae on Delos [52]) and

(d) Large public lavatories used by more than 10 to 20 people. These were generally constructed during the Roman period (Figure 22).

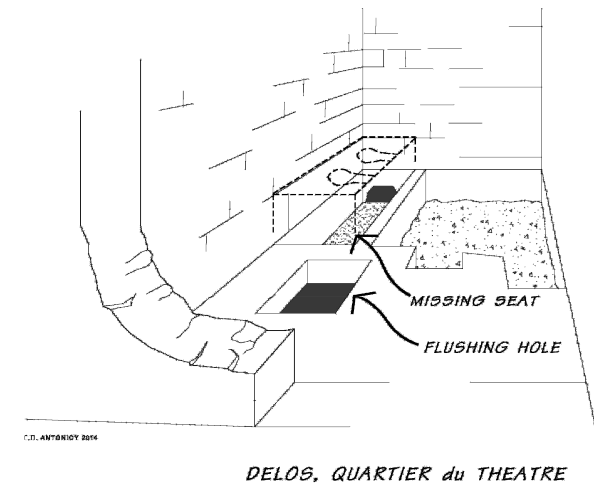

(a)

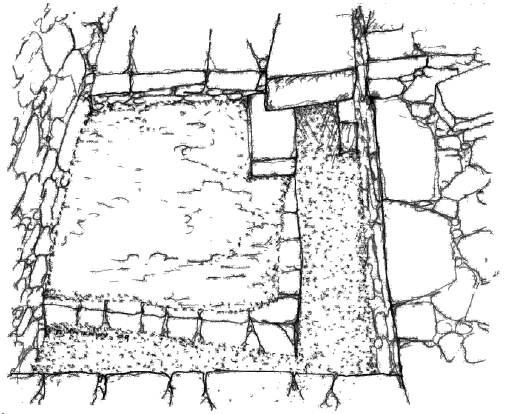

(b)

Figure 21. Delos, houses' lavatories: (a) with flushing hole and (b) L shape lavatory, house IV B (the seats were probably wooden—sketches by G. Antoniou). 


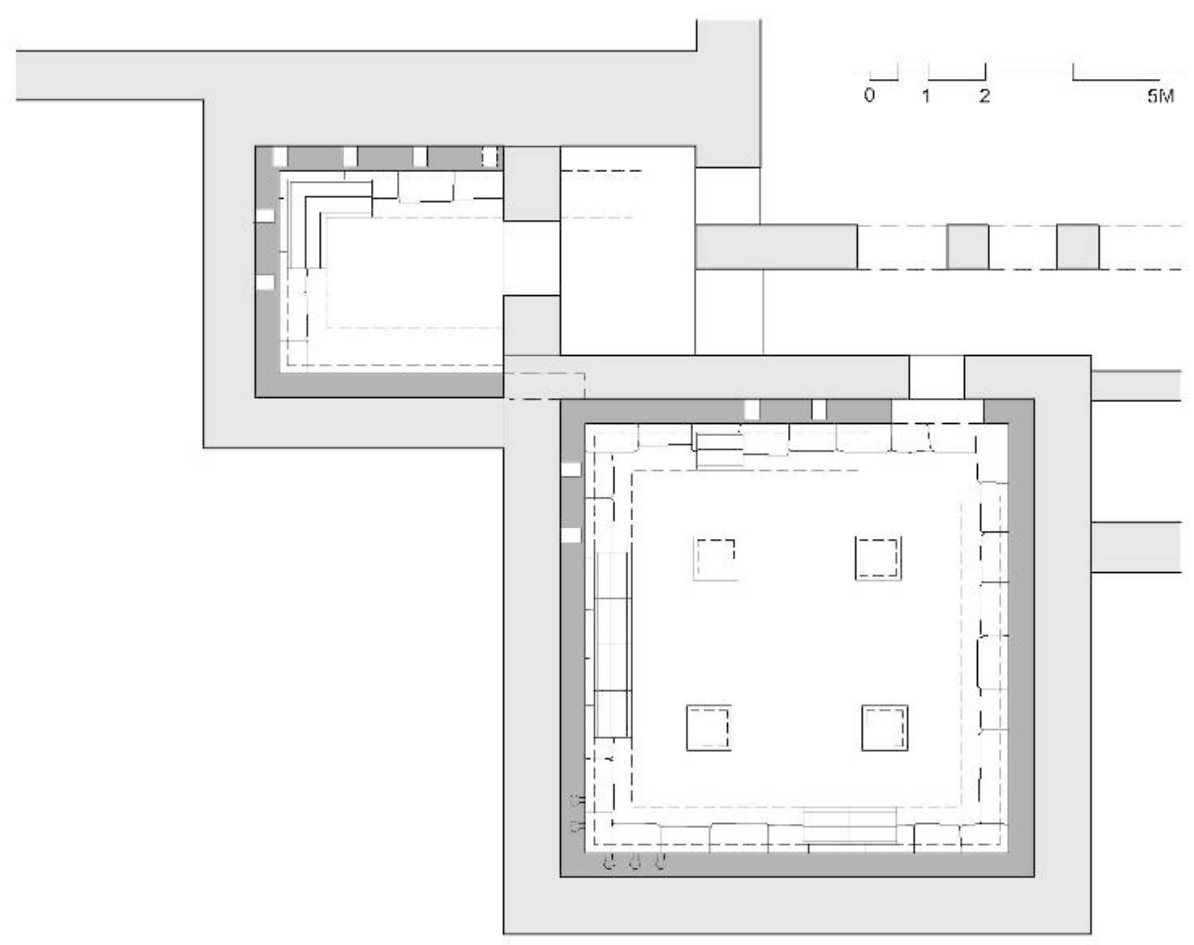

Figure 22. The lavatories of the Asklipeion in Pergamon. The older multi seat elongated one was adjoined in Roman era with a large square latrine (G. Antoniou, drawn after [53]).

Most of the ancient names for toilet mentioned at the beginning of this section refer to a private place (the part- $\alpha \pi \hat{-}-a p o$ ). Despite this, the excavation of many private lavatories clearly demonstrates evidence for their simultaneous use by more than one person. Even in residences where the inhabitants numbered 5-10 people, there were lavatories with two up to four defecation openings. In these cases, it is unclear whether there was a simultaneous usage by residents of different sexes. Public latrines were used by dozens of people simultaneously, and often more than 50 (Athenian Agora, [54]); Pergamon, Asklepeion (Figure 22). This was a practice which expanded during the Roman era and survived in many Byzantine and medieval lavatories of the Eastern Mediterranean area and western Europe as well, including monasteries [55], baths [56] and castles such as Acre in Israel (Figure 36) and even at Mytilene's (at the 16th c. semi-subterranean refuge). These examples are discussed more in Sections 6.1 and 6.2.

\subsection{The Roman Period (ca. 1st c. BC-4th c. AD)}

Ancient Roman toilets were public and private [57,58], public multi-seat toilets accessible in public areas (foricae), or private toilets with one, two, or more seats $[59,60]$ directly into cesspits. Some latrines were situated within residential interiors, often in the kitchen. Cesspits associated with latrines were also located on the interiors of Pompeian homes. In some houses, the depth of cesspits corresponds to that of a large amphora (dolium), while in others, the cesspits measure up to $10 \mathrm{~m}$ deep. When full, the portable receptacles would have been removed by stercorarii (a specialized category of slaves) and replaced by another vessel. For cleaning purposes, water was either poured down the toilet or males urinated directly onto the tiles [59,61]. Disposal of domestic human waste with water was a late development in Pompeii. In fact, some residences were equipped with flushing toilets connected to the piped water supply in the post-Augustan period [62], arguably when Pompeii was served by the Aqua Augusta [63]. Pompeian toilets generally had sloping floors in front of them, and they often consisted of wooden seats resting on stone supports, which surrounded the entrance to the cesspit or drain [64]. Some foricae were built in the Forum, the Gymnasium and some of the baths after the earthquake in $62 \mathrm{AD}$ [65]. The remains of the multi-seat latrine in the northwest corner of the Forum are shown in 
Figure 23. The protruding stonework around the edges of the latrine would have had wooden seats resting on them. Beneath the seats, a flow of water flushed away waste toward the drain [1]. Usually, shops and bars had toilets in Pompeii. Moreover, as reported in Hobson [59], in some areas of the archeological site, there are a number of single rooms opening directly onto the street that have been identified as latrines.

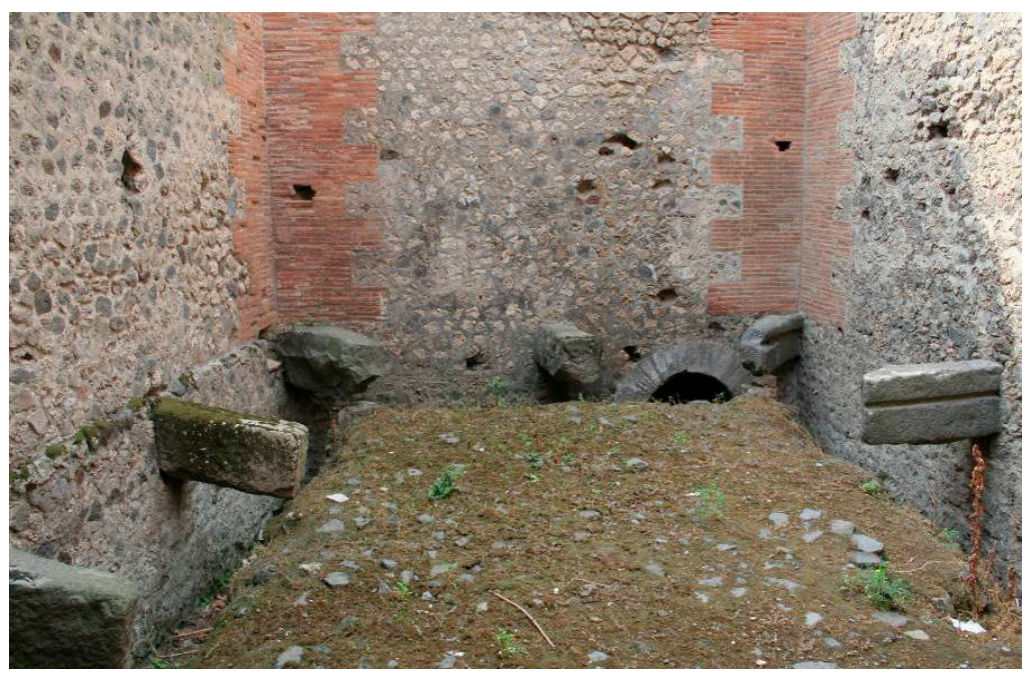

Figure 23. Remains of the multi-seat latrine in the Forum of Pompeii (photo courtesy of Giovanni De Feo).

In the town of Herculaneum, that is only a few kilometers from Pompeii, the number of cesspits and the distribution of toilets is significantly different from Pompeii [59,64]. First of all, in Herculaneum there was a limited presence of cesspits mainly due to the fact that the ground is too rocky for draining away urine and feces [66]. Secondarily, toilets are less frequently seen in residences and more frequently visible in association with commercial or public uses. In Herculaneum, toilets occurred in public baths and commercial spaces such as workshops and taverns (taberna). Toilets were located in domestic, as well as commercial, buildings [61]. The only multi-seat latrine, whose remains are shown in Figure 24, supplied the men's baths (thermae) [59].

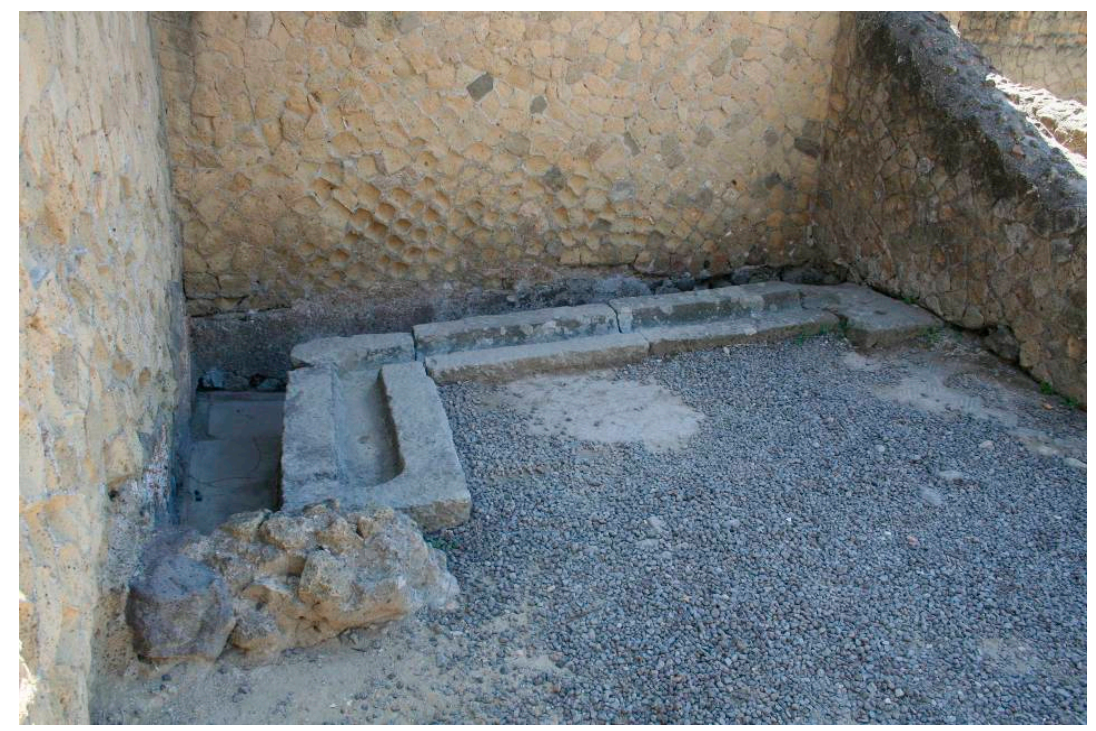

Figure 24. Remains of the multi-seat latrine in the men's baths in Herculaneum (photo courtesy of Giovanni De Feo). 
The remains of what is commonly considered the most famous multi-seat Roman latrine are in the archeological site of Ostia, near the Forum (Figure 25). The official placard describing the remains reads: This public latrine (forica) was installed in what had previously been two shops, near the Forum Baths, perhaps when the Baths themselves were repaired in the Late Empire (4th c. AD). The stone seating is still preserved around the walls, and there is a small basin next to the pillar which separates the two doorways into the room.

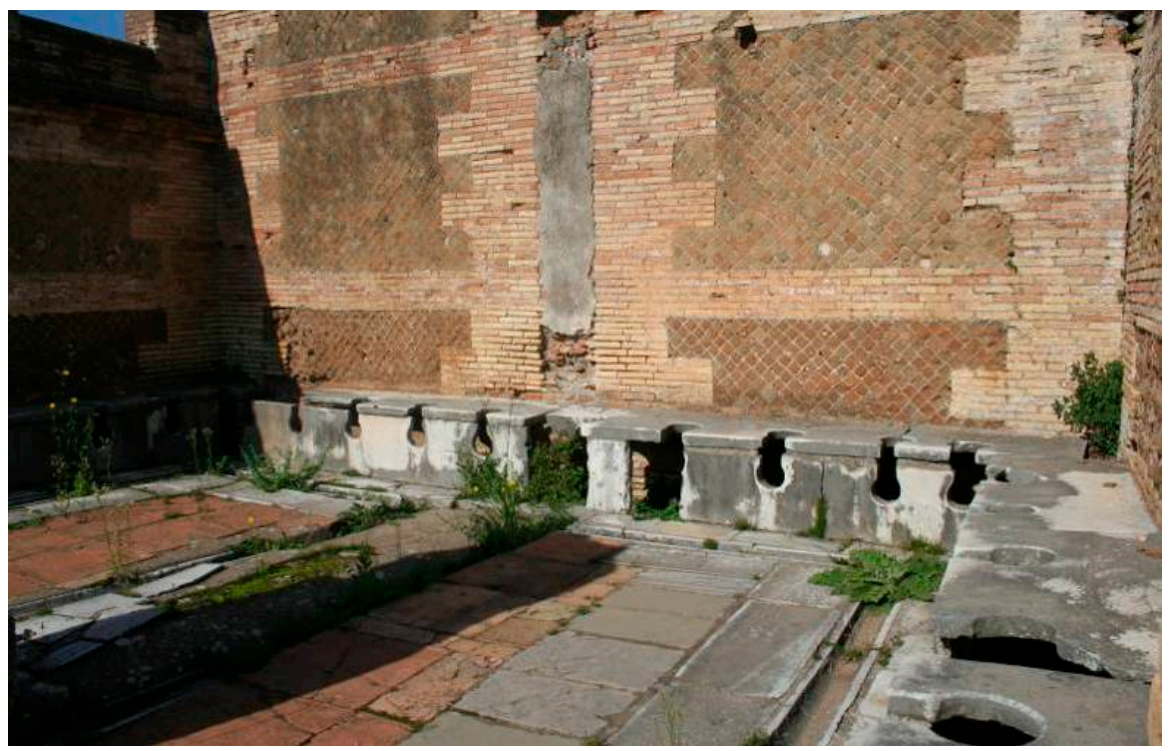

Figure 25. Remains of the most famous multi-seat Roman latrine in the archeological site of Ostia, near the Forum (photo courtesy of Giovanni De Feo).

Due to their intrinsic nature as well as general and specific (namely in terms of hygienic conditions) knowledge limitations, Roman toilets were clearly far from hygienic [67] (p. 162). Moreover, Romans must have contracted many (for them deadly) diseases from using these toilets, resulting in a high mortality rate [67] (p. 162).

\section{Post Antiquity and Medieval Times}

\subsection{The Byzantine Practices (4th-14th c. AD)}

Wastewater and lavatory technical practices and the relevant applications during the Byzantine period present interesting characteristics related mostly to a combination of various historical aspects, as the partial continuation of the ancient tradition and practices, the barbaric raids and their results, the social reformation due also to the Christianity, the power of the Church within the state, and so on. The Byzantine state, which originally preserved the Roman name, continued in many ways and somehow 'inherited' the Greco-Roman civilization of the antiquity. Thus, the new state adapted at its beginning not only administrative institutions, but also the constructional and technical achievements of the pre-existing empire. The Greco-Roman civilization survived mostly in the eastern part, since after the 5th c. AD, the western part was lost due to the barbaric invasions. Therefore, the medieval characteristics of the west remained away from the east for quite long time. Several typical ancient Greek and Roman formations can be traced in the applied wastewater and storm water technologies, as well as in the lavatories built until the 8th c.

During the early centuries of the Byzantine state, typical antiquity toilets (Figure 26) can be found in complexes as in Marea (6th to 8th c. AD; [68]) and like the double bath at the pilgrimage complex of Abou Mina (end 6th c. AD) in Egypt [69]. In both cases the toilet is adjacent to the bath, but closer to the entrance or the disrobing hall or the entrance patio. This position complies with the written 
sources regarding life in the Byzantine era, which states that the users in the baths were visiting the toilet after undressing and before entering the bath, for obvious hygienic reasons. Moreover, it can most certainly be concluded from the surviving remains that lavatories were used by many people simultaneously, despite their use almost two centuries after the official end of the ancient religion and the prevalence of Christianity which promoted privacy. During that period not only single seat toilets are constructed in old buildings [70], promoting privacy, but also single bathing chambers are incorporated in preexisting Roman baths, which originally had only common bathing pools, as in Epidauros [71]. Construction wise these toilets were supplied by water through pipes or the ditch system of the bath, possibly reusing water out of the main use of the bath as well. In Marea, an entry chamber (Figure 26) resembles similar plans found during the very end of the Hellenistic period, i.e., in Athens [54] and references in [72]. Their placement at the outer zone of the building served as well for the sewage, like the way it was usually applied at the ancient lavatories, that is, in Delos, Dystos, Kos, etc. (see Section 5.1; [9]). It seems that the collective use, the connection or attachment to bathing facilities, and the semi-perimetric ditch, supplied by the bath water or separate stream water (as in Aksaray Sultan Han, and Incir Han), are characteristics that survived up to the 12th to 13th c. and are found at Selcuk—or Rum Selcuk according to Prof. Kiel—Hans-Caravansarais in Anatolia [73].

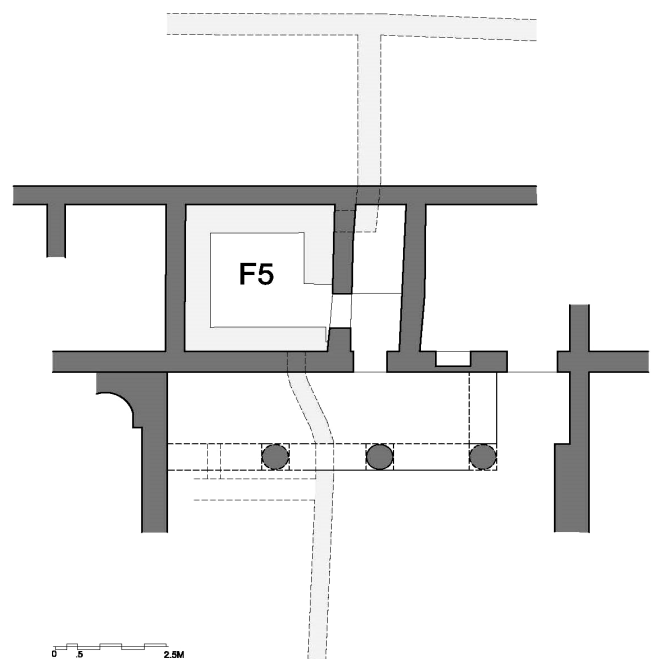

Figure 26. Lavatory at Marea baths Egypt. Water-wastewater (underfloor) ditches in gray (G. Antoniou, inspired after [68]).

Monastic lavatories with a collective character are not rare in the greater region of the eastern Mediterranean during the first Byzantine centuries. The row of the collective latrines at St. Symeon monastery in Assuan, Egypt (Figure 27a, number 44) and their placement leads to the existence of a kind of sewage. On the other hand, a similar row at the great eastern tower (ca. 6th to 7th c. AD) of St. Catherine's monastery at Sinai (Figure 27b; [55]) had undoubtedly a collective use, but the waste was drained exactly outside the walls, via pipes through the thickness of the towers' wall. Similarly, the lavatories of the Zygos monastery in Mt. Athos, in Greece-dated ca. 10th c. AD-have a similar layout, but placed outside the walls, attached to them [74]. On the other hand, it is not certain if it was operating as a collective toilet or not, forming just a row of toilets. The waste was also drained directly outside via inclined pipes (as also in Figure 28).

Despite the numerous examples of collective use lavatories, there are surviving private or semiprivate toilets in monastic buildings. A characteristic case is the combination of private and semiprivate toilets in the QR 195 hermitage dated early 7th c. AD [75,76]. There, a chair-type toilet was applied in single or twin layout. The private toilet became part of the typical layout of the Byzantine Monastery and was constructed not only at the wings of the cells, but also in other buildings of the complexes, as the Estiae (Figure 29), the Hospitals, and the Guest Houses. In some cases-as in the 
Hospital of Mega Meteoron monastery-where a separating wall is absent, there was probably a wooden partition [77]. Doors resembled a kind of curtain, the so-called velothyron [78]. In many cases, there are pipes draining out the waste, inclined as in Vrontiani monastery in Samos (Figure 28), or vertical as at the lavatory of the Mega Meteoron Hospital (Figure 30). On the other hand, there are monastic literal references about cleaning or removing the waste $(\ldots \sigma \alpha \rho \dot{\omega} \sigma \alpha \tau \omega \tau \alpha \lambda \dot{u} \mu \alpha \tau \alpha \ldots)$ [77]. This leads to the conclusion that there was not a sewage system in every case.

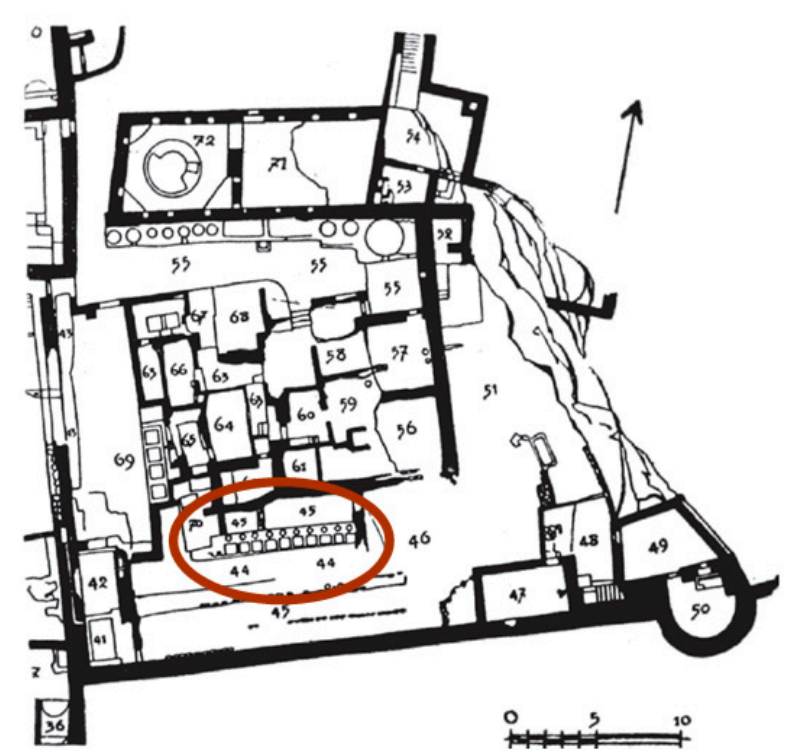

(a)

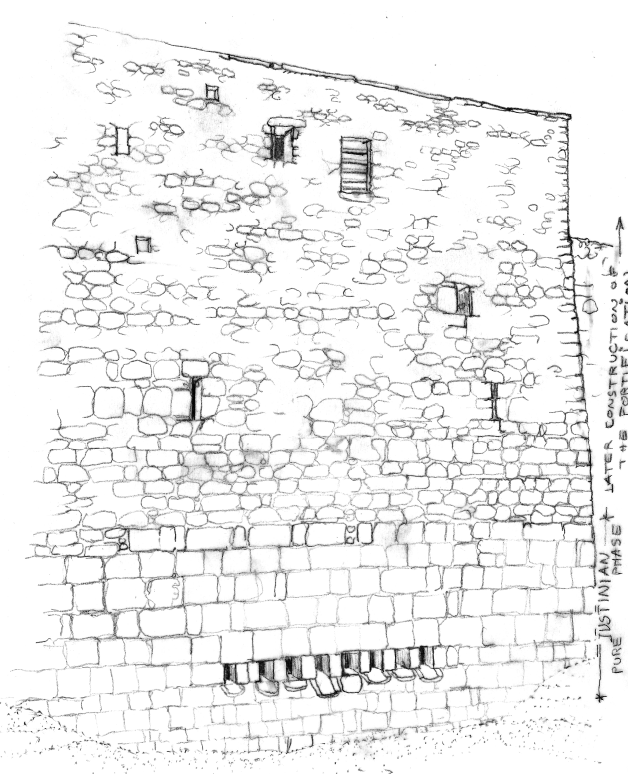

(b)

Figure 27. Late antiquity lavatories: (a) Collective lavatories (\#44) St. Symeon Monastery, Egypt [78] and (b) St Catherine's Monastery, the outlets of the lavatory in row in the SE Justinian tower (G. Antoniou inspired by photograph of Panoramio K. Haraburda [79-83]).

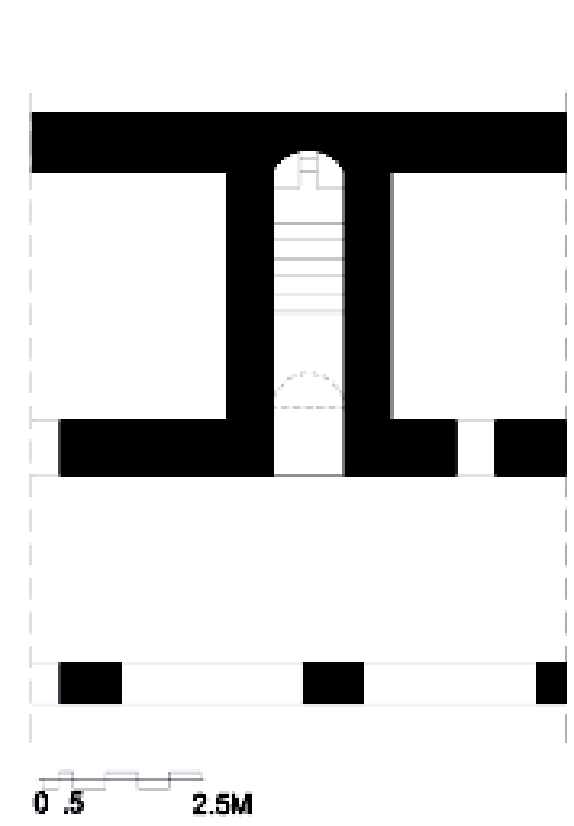

(a)

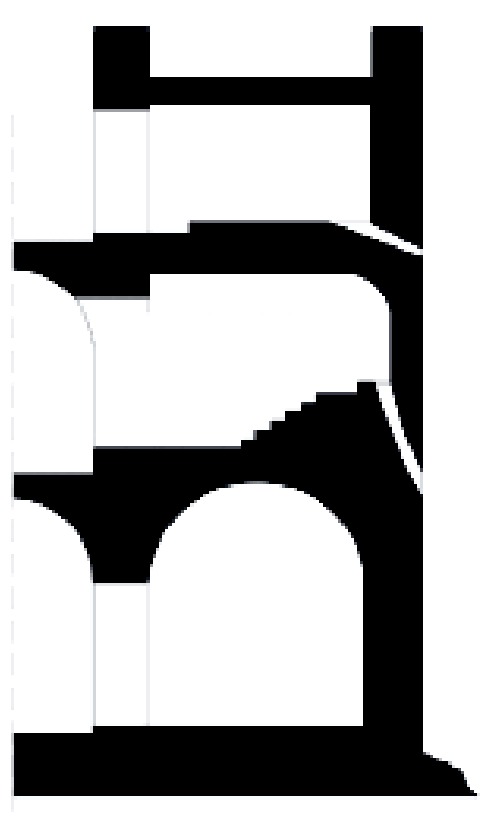

(b)

Figure 28. Toilets in narrow chambers between monks' cells in Vrontiani Monastery Samos, Greece: (a) Plan and (b) section (G. Antoniou after [77] with modifications). 


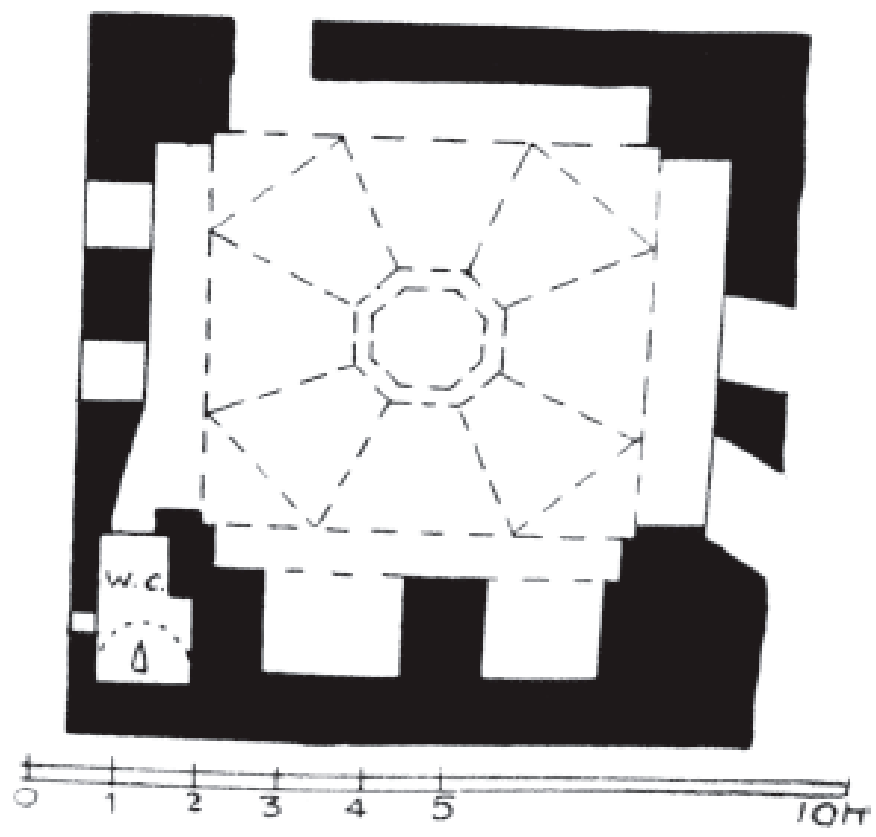

Figure 29. Toilet at Estia (fireplace) of Helandarion monastery Greece (adapted from [72]).

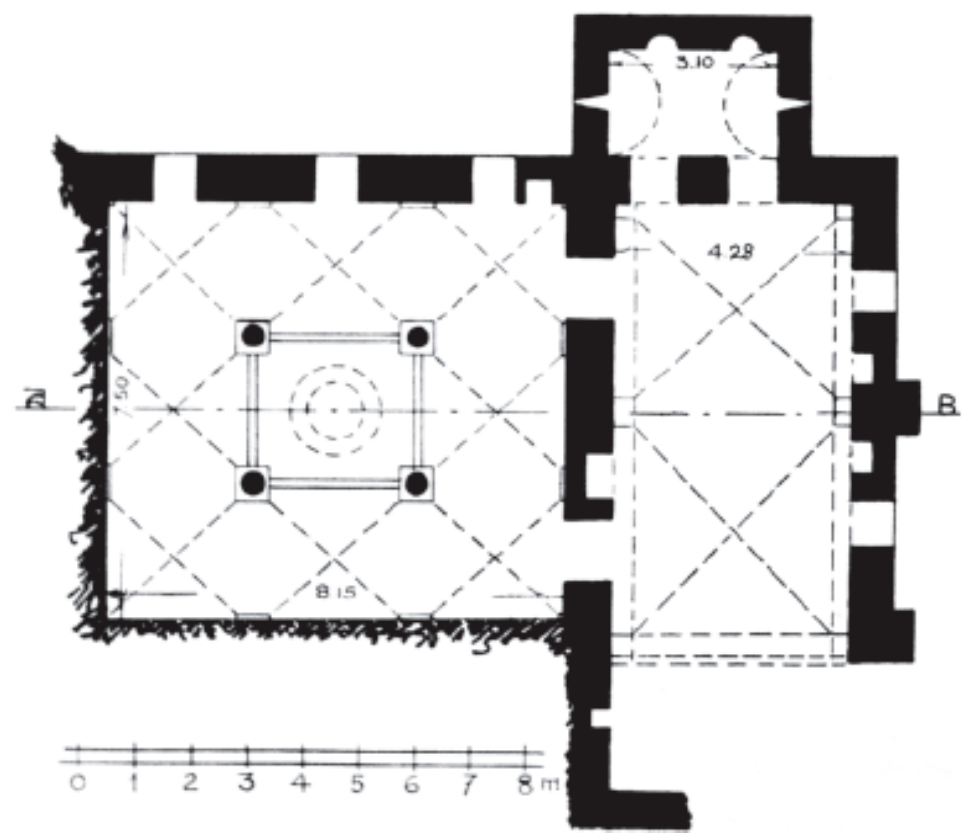

Figure 30. The protruding two seat lavatory (in $5 \mathrm{~cm}$ ) at the hospital of Mega Meteoron monastery, Greece, had possibly a light separating wall or curtain (adapted from [72]).

In contradiction to the fact that there are some references of using water out of the monastery's cistern like in Nea Moni in Chios [77], not much information exists about the way the toilets were supplied with flushing water. In most cases, a bucket would have been used. Most probably the residential toilets were flushed in a similar way. On the other hand, many surviving structures, like the residences of Mystras in Greece, imply that a waste pipe network existed. It consisted not only of vertical pipes, but also of clay pipes under the streets [84]. These pipes coming from each house were centralized in a junction point, and were led to the town's sewage network. Moreover, the owners were responsible for the maintenance of the pipes up to the junction point [84] (Figure 31a). The residential byzantine toilet was protruded (Figures $31 \mathrm{~b}$ and 32 ) and situated at the corner or side of the main 
chamber of triclinion, found often in each floor. Their usual semicircular edge, rather than their vaulted ceiling, was the reason of the term exedra, one of the names that had been given to the toilets by that time [84]. Traces testifying domestic twin or triple toilets are very limited, and in Salonika coexist with a typical single toilet [85].

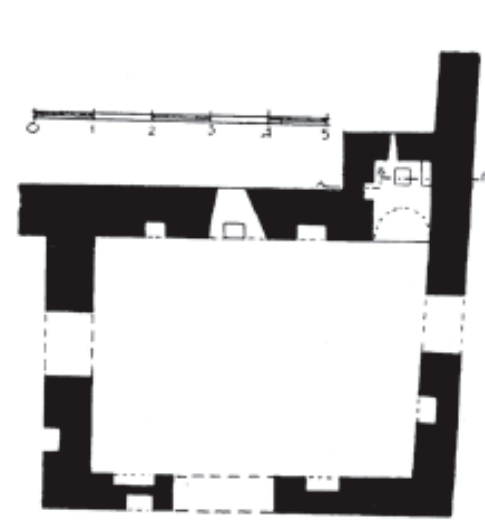

(a)

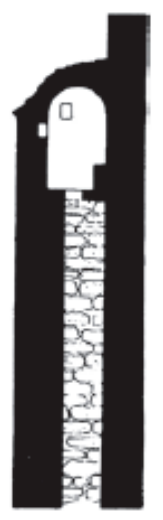

(b)

b)

Figure 31. Two mansion house chambers with toilet in Mystras, Greece. (a) Toilet placed at the corner of the chamber and (b) placed in the middle of the long side: [84].

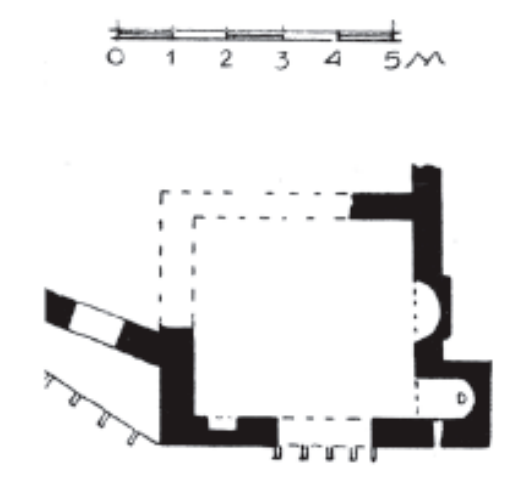

(a)
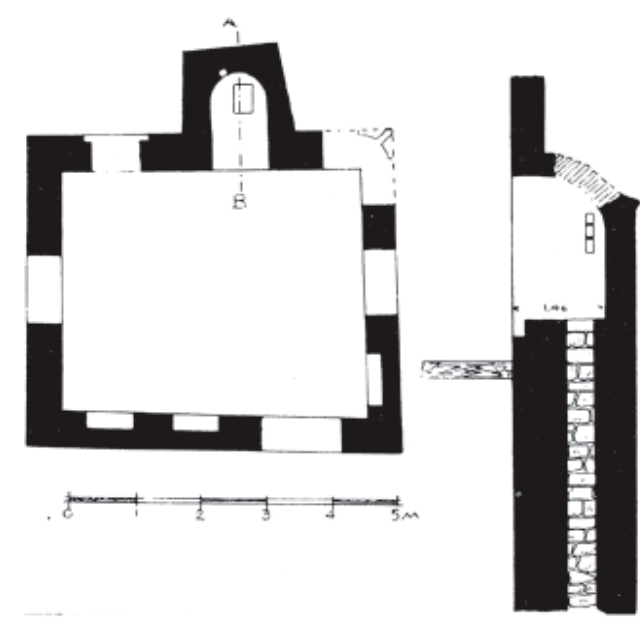

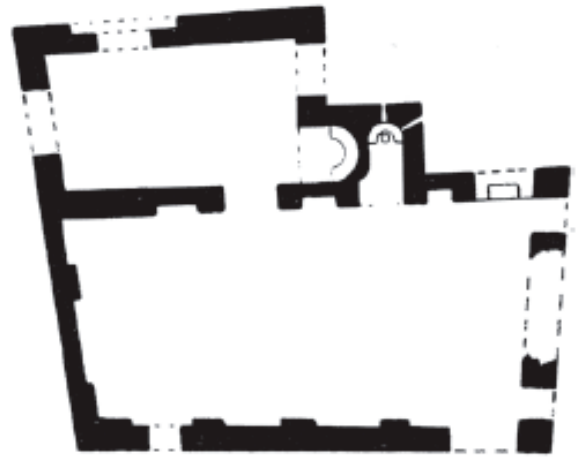

(b)

Figure 32. Chambers with single toilets in small protruding niches, in Mystras. Greece: (a) oridinary house and (b) Mansion house (adapted from [84]).

Similar protruding residential-type toilets—-with or without a sewage pipe-dated in the mid-and late-Byzantine period survive in some monasteries of Mt. Athos [86]. Illumination was provided by oil lamps inside small niches on the walls. Written sources about $24 \mathrm{~h}$ burning oil lamps in monasteries' typikon refer also to the toilet oil lamps [77].

Concerning the toilets' drainage, from the majority of the archaeological findings, it seems that the wastewater and storm water networks were inferior to the relevant Hellenistic and Roman ones. Later, information about mature Byzantine settlements as Mystras, refer to both piping networks [84] (Figure 31a,b) and individual residential water-tight cesspits [87].

\subsection{The Venetian Period (11th c.-17c. AD)}

A separate, from the remaining medieval and Renaissance European examples, discussion of the Venetian practices can be justified by the reasonably stronger influences from the lavatories of 
the eastern Mediterranean where the technologies of the antiquity survived more than at the other western parts. It seems that these influences were combined with the practices of the rest of the European knowhow.

The Byzantine state was weakened from crusades and Ottoman invasion and was unable to retain sovereignty over several provinces in Eastern Mediterranean. The Venetian Republic became dominant and ruled the trade in that region. Many cities flourished during the Venetian period. Under the rule of Venetians, many fortresses, which were later improved by the Ottomans, were built. Also, rain water cisterns, aqueducts, irrigation windmills and other water infrastructures were constructed. However, during this period water availability, quality, and sanitation were at a low level. Several cities suffered from the lack of water and wastewater management.

Venetians, however, built advanced wastewater and drainage systems in several castles and fortresses, usually located in coastal areas. Such castles and fortresses can be found all over the Eastern Mediterranean, such as in Corfu, Lefkas, Methoni, and Koroni and many others in the Ionian region at Chanea, Rethymnon (Fortetsa), Iraklion, etc., in Crete but also in Keryneia, Lemessos, etc., in Cyprus and many others in that region. Beside other well articulated constructions in the castles, the Venetians constructed water supply and drainage systems for protection from stormwater, as well as lavatories. These constructions were quite sophisticated for that time. In several cases, the rainwater and the sewage from the lavatories were directly discharged to the moat or the sea. In addition, during the Venetian period, just like during the late Byzantine times, the construction of lavatories reflected the need for privacy, which was imposed by social and religious factors. Moreover, they reflected the lack of spacious housing within fortresses. The result was small spaces for the defecation (the absolute necessary), similar in most cases to the examples of the Byzantine era, presented above. The examples in the castles are mostly typical European garderobes (see below in Section 6.3). Even in countryside houses (like in Chromonastiri in Crete, Figure 33) and other spacious buildings, the size of the lavatories was limited, following the practice of garderobes. On the other hand, their location was next to the most private sectors of the residences, such as bedrooms, in contrast to the ancient houses, in which they were placed closer to the entrance or commonly accessed areas. However, in both cases their position was at the perimeter of the building.

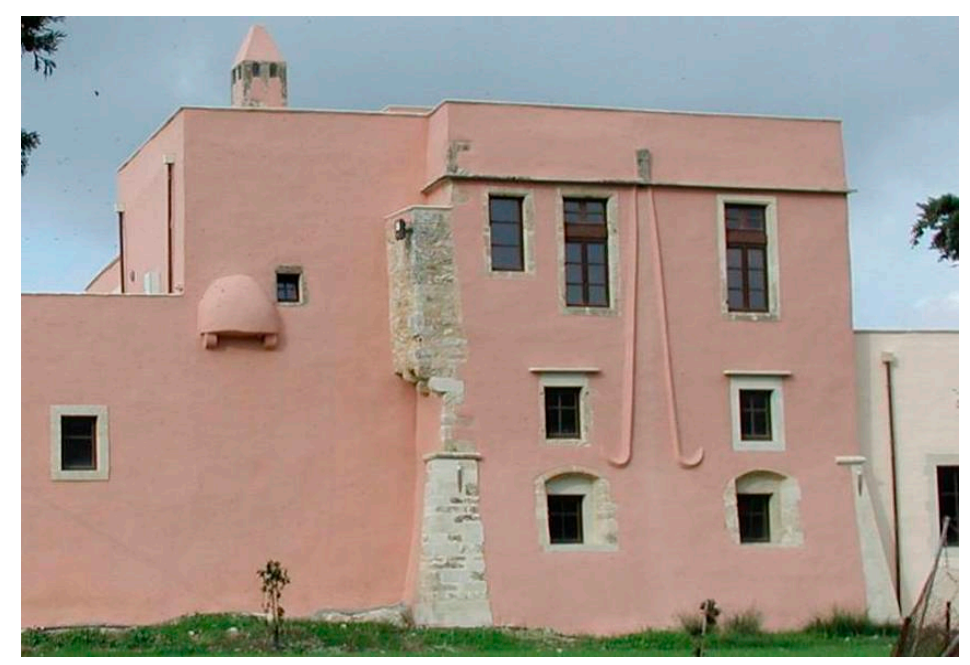

Figure 33. Protruding privy-garderobe at the second floor of a rural residential complex in Chromonastiri on Crete (courtesy of G. Antoniou).

Despite the several common lavatories of the Early Christian period, accommodating multiple users, that have been recorded in monasteries (e.g., in Sinai and in Egypt see Section 6.1), from the Venetian period, mostly small private toilets can be observed. In contrast, in several early dated monasteries in Northern Europe latrine or reredorter (or necessarium from the East) chambers were 
accommodating many monks. Examples may be found in Scotland, such as in the Saint Andrew Cathedral Priory, the Dumferline and the Inchcolm Benedictian and Augustinian Abbeys [88]; they will be presented more in Section 6.3 .

Small protruding niches on the higher floors of the buildings, with free open air drainage, were quite common practice for the toilets in the late Byzantine and Venetian periods, and several lavatories of that type are preserved at the monasteries of Mountain Athos [89]. This is in contrast to typical Byzantine buildings which had a built-in drainage conduit [72,86]. Despite that, there are cases, especially in fortresses, such as in Lemessos, where a closed vertical pipe conveyed the wastes to a cesspit located on the ground level, (Figure 34) which also happens in several garderobes (see below and [90]).

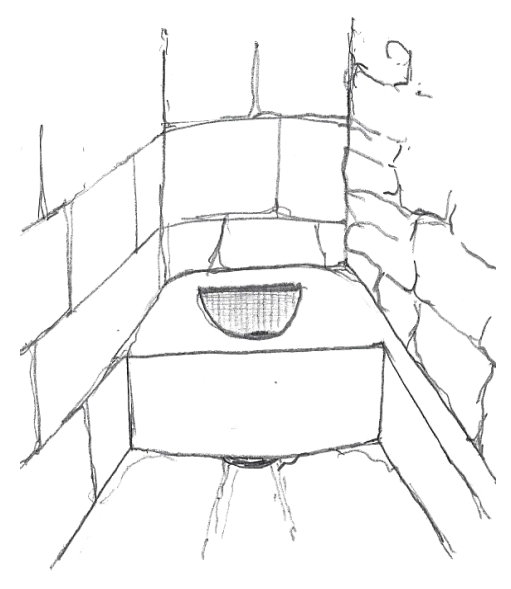

(a)

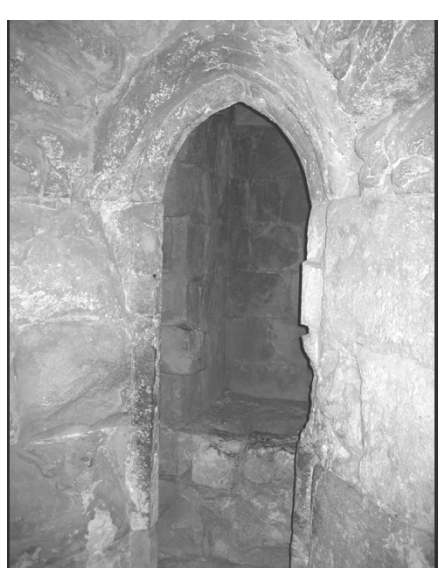

(b)

Figure 34. Lavatories (garderobes) at: (a) 40 Colones Castle Cyprus (sketch by G. Antoniou) and (b) Castle of Lemessos, Cyprus (with permission by G. Antoniou).

\subsection{The Medieval European Practices (8th c.-15th c. AD)}

The intact surviving examples of the European medieval lavatories are not much. They are mostly constructions-or mostly their remains-of monastic communal lavatories the necessaria or reredorters' as it was briefly mentioned above. On the other hand, small toilets, privies and garderobes remained or are restored at the various castles, towers and fortifications. Their concept seems to also have been adopted also for residential cases as it can be concluded by their existence in proverbs of that era (Wikipedia, Netherlandish Proverbs). The most common feature for most of the mentioned types is the usual free disposal of the waste, either at a moat or just outside the enclosure (i.e., at the sea in Portchester Castle) or generally the building. During the High Medieval times, inner drainage networks start to appear [90] but can be considered as exceptions.

The application of that type of lavatory was predominat for the European practices, presenting a variety of forms, disposal networks and material combinations. It seems that this predominance remained until the establishment of the water closet.

\subsubsection{Lavatories Installations in Central and Northern Europe (8th-15th c. AD)}

As it was mentioned above there were two main kinds of lavatory in the Middle Age, the small private ones and the communal ones. Most of the surviving communal examples, either ruined or restored, are found in monastic building and fortified constructions. In several mid and high Middle Age monasteries in most European regions, reredorter or necessarium chambers were accommodating many monks, like the ancient lavatories. Examples may be found in Scotland, such as in the Saint Andrew Cathedral Priory (Figure 35, the Dumfer line and the Inchcolm Benedictian and Augustinian Abbeys [88]). These evidences suggest the continuation during these times of the Roman tradition, 
but adjusted to the ethics of the era, by using separating screens [91]. That continuation most possibly occurred through the early Byzantine examples from the Holy Lands region (Palestine, Sinai and Egypt) monasteries which pilgrims had visited. The crusades' lavatory at Acre Castle in Israel (Figure 36) closely resembles the multi seat Roman lavatories and could be considered as an example derived by originals, even though mostly the height of the seat refers more to a squat formation rather than to a typical sitting ancient one. This example incorporates the usual (St. Andrews Abbey, Inchcolm Abbey, etc.) single longitudinal sewer duct under the floor. Relevant to those early eastern paradigms, it can be found also in the north of Europe, as the embodied in the fortification walls or towers common lavatories like the case of the Portchester Castle-Benedictine Priory in England (ca. 11th c. Figure 37). The resemblance of the chutes with the outflows of the lavatory at the Justinian tower at Sinai monastery (Figure 27b; [55]) is obvious but the main body of the building behind the wall is missing nowadays.

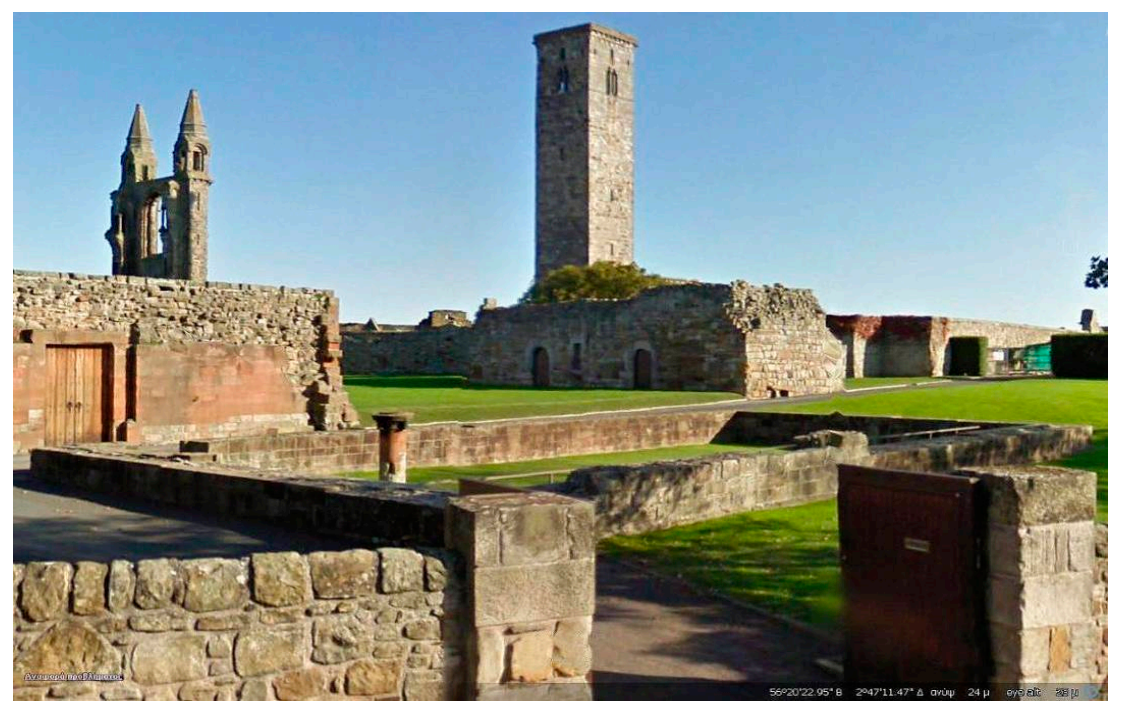

Figure 35. The remains of the elongated Reredorter of St. Andrews Abbey in Scotland. The deep drain is visible along the side towards the enclosure (Google Earth, street view, 2015).

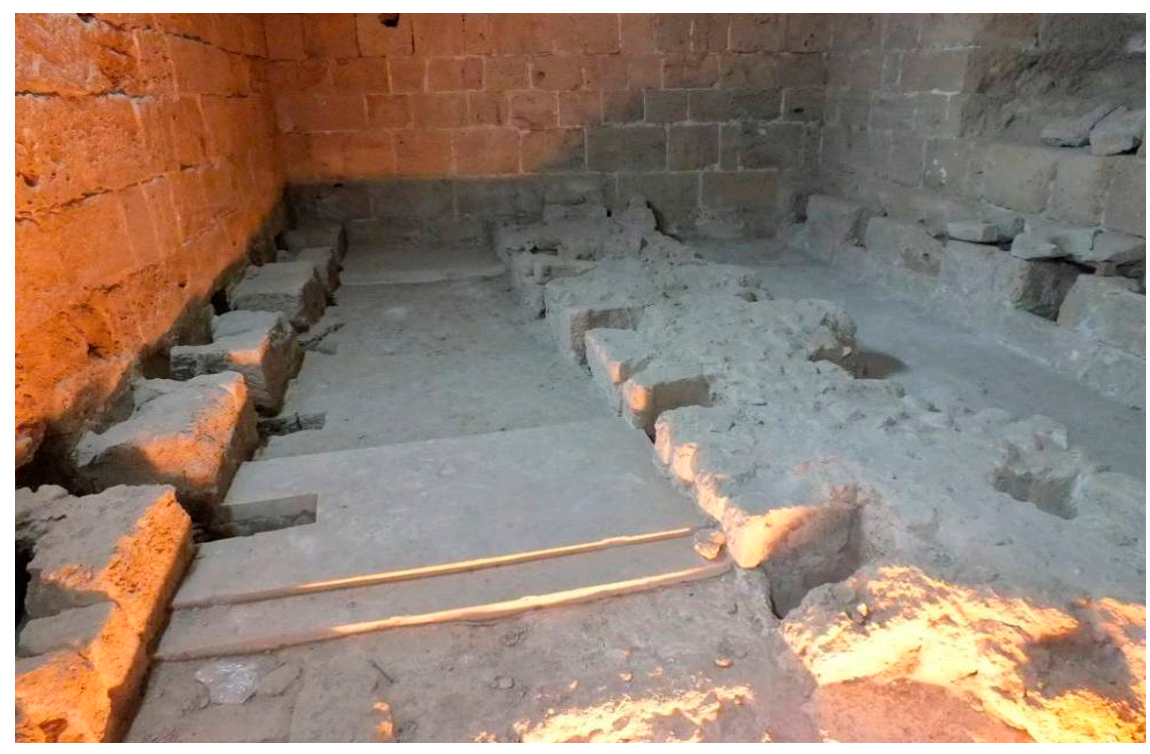

Figure 36. Crusades Lavatory in Acre Castle Israel [92]. The formation refers mostly to a squat type toilet rather to a sitting one. 


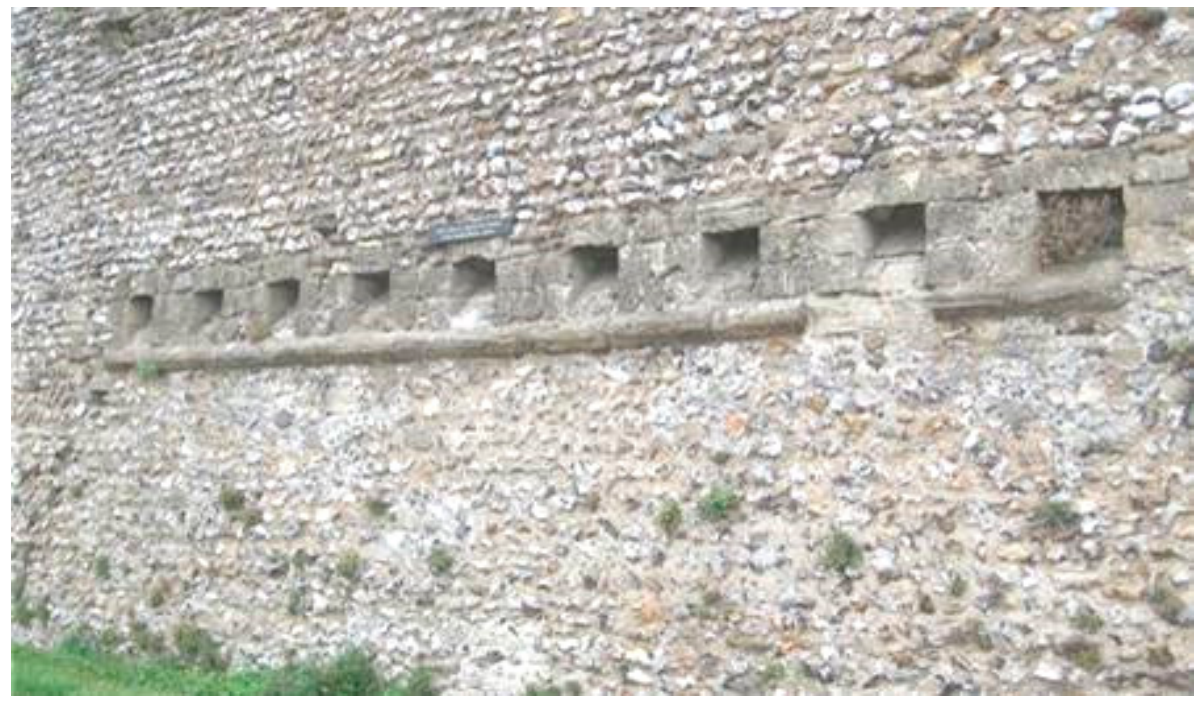

Figure 37. The latrine chutes on the enclosure walls at the Portchester Castle-Benedictine Priory ca. 11th c. [79-83]. The resemblance to the lavatory at the tower of Sinai monastery dated in the 6th c. (Figure $27 \mathrm{~b}$ ) is obvious.

The reredortes were situated usually in the vicinity of the dormitories (dorters) or chambers but originally not attached to them. A corner tower as in Southwell palace was a typical case. A relevant formation of not attached to main chambers toilets were found also in castles as the Langley Castle in England (Figure 38). Semi-detached towers, as in Incholm Abbey, Scotland, or even highly detached ones as in the Kwidzyn Castle (actually an Ordensburgen in Poland (Figure 39) was accessed by covered passageways ensuring a safe distance against odors! In most cases of tower lavatories, the disposal of waste was to cesspits, rather to the moat or to an open ditch.

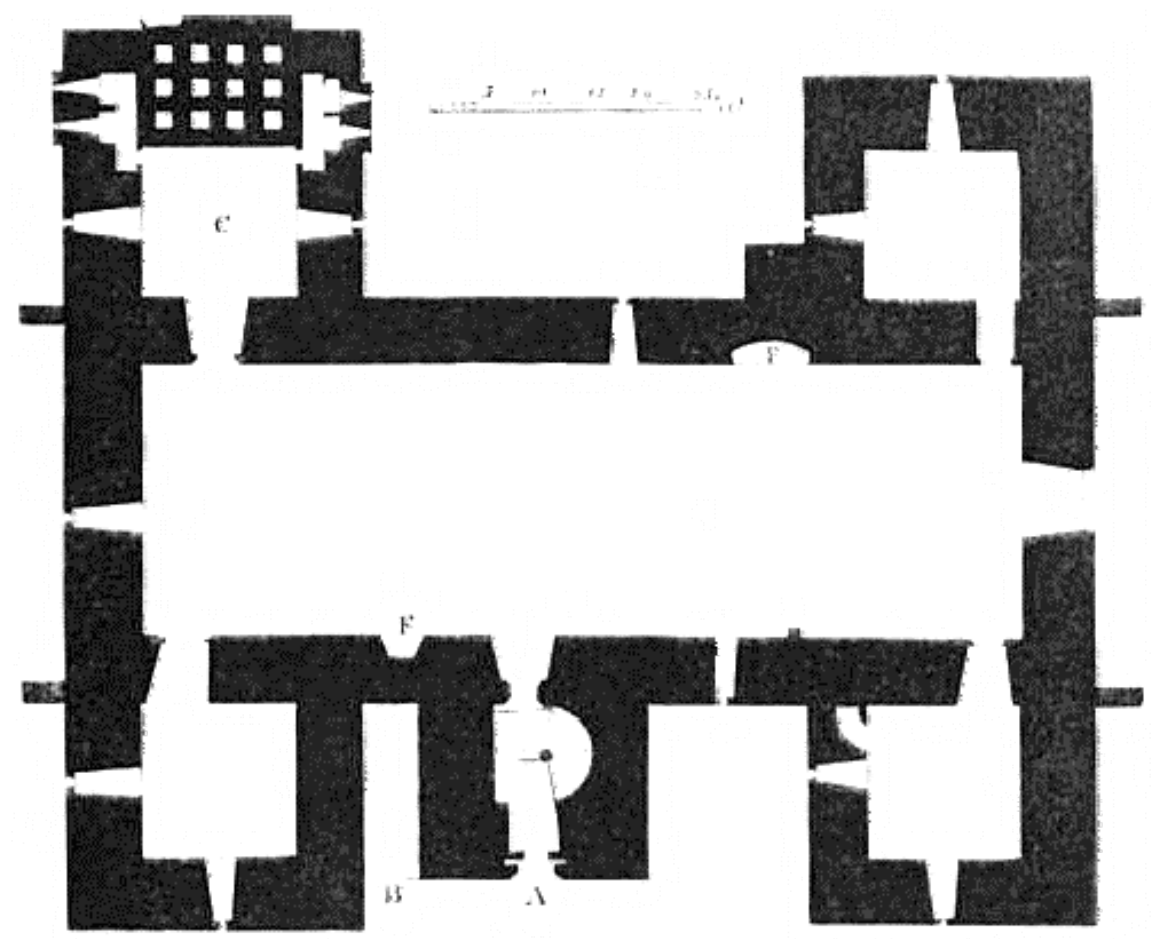

Figure 38. Ground plan of the Langley Castle. In the tower $C$ there are the 12 shafts of the relevant three stepped sets of garderobes deployed at the three upper levels [93]. 


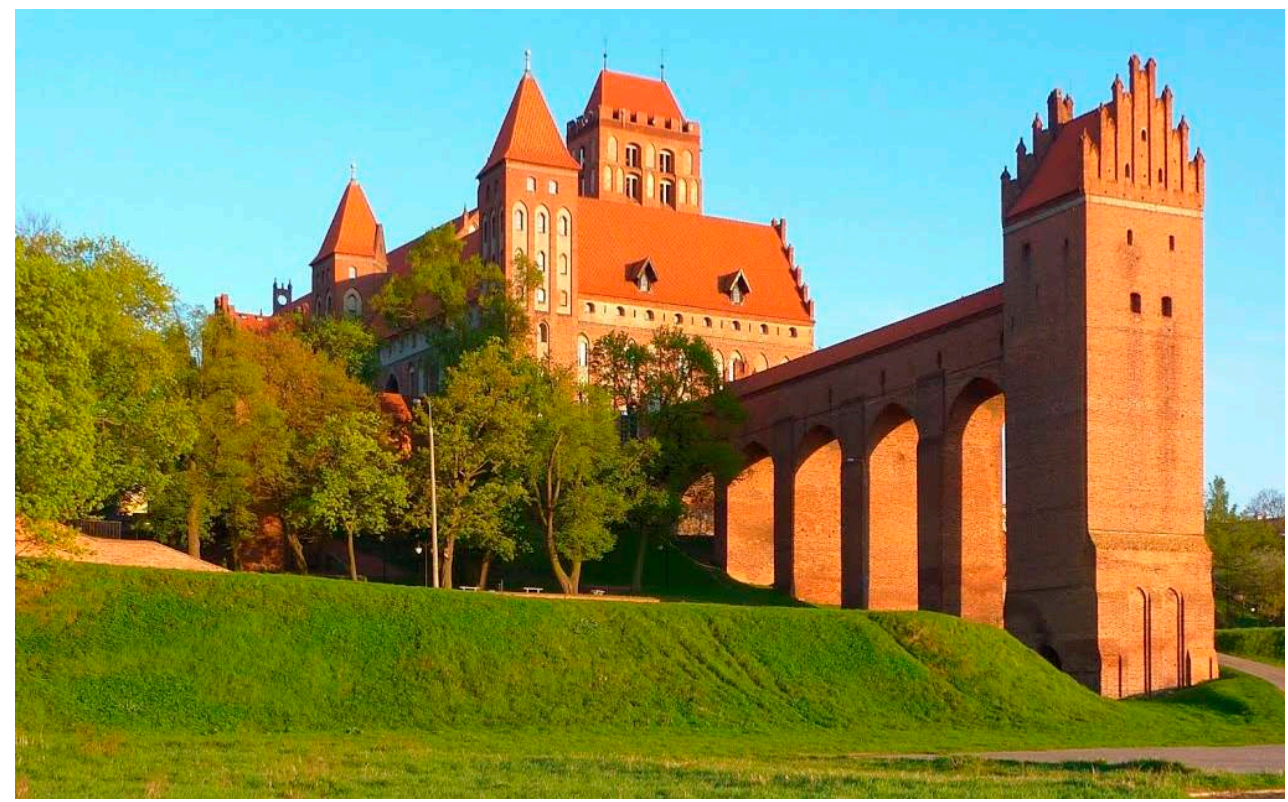

Figure 39. Kwidzyn Castle Poland. On the right the high detached lavatory tower. On the left, behind the trees, the short detached lavatory tower (Panoramio, Knapczyk, 2015) [79-83].

Garderobes were the most common toilets for both military and residential (see Figure 40) uses in the Middle Ages. They were simple constructions, protruding out of the wall, usually covered or semi covered (Figures 40c,d, 41 and 42). The waste was usually discarded freely outside to the moat or even to the street. Inclined ducts in the walls discarded waste in to the moats (Figures 37 and 40b). In some cases, there were cesspits incorporated in the structure (Figure 40a) or type of midden pits accessible from the inner side (Figure 40d). Rarely they were deployed in multiple levels as in Langley Castle (Figure 38).
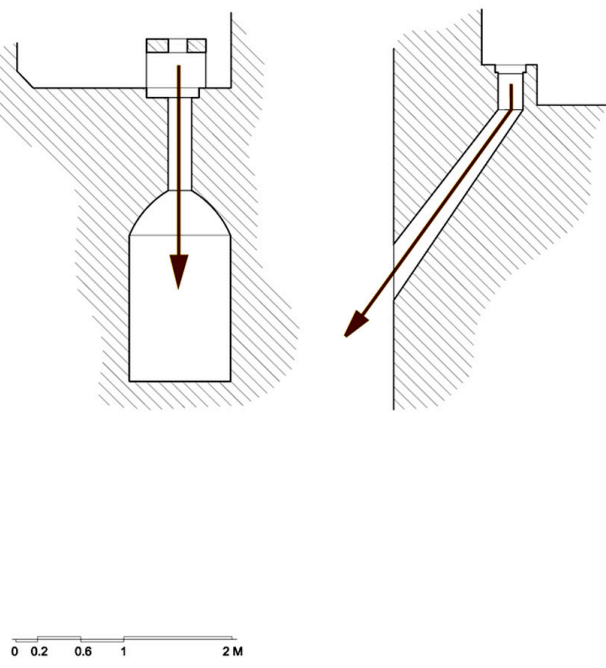

(a) (b)

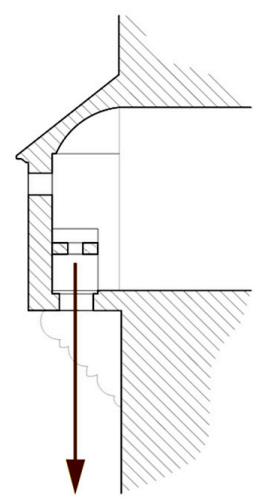

(c)

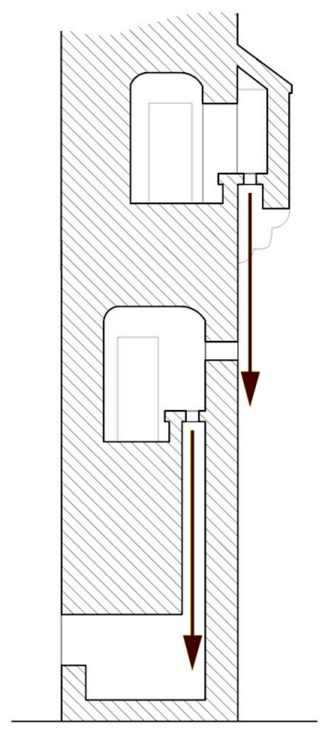

(d)

Figure 40. Four characteristic types of garderobes with a variety of formations and waste disposal (G Antoniou, inspired after [90]). 


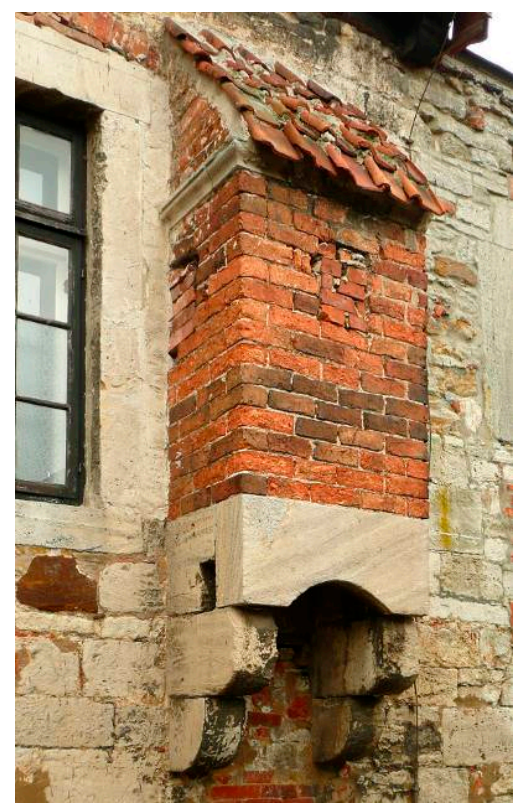

(a)

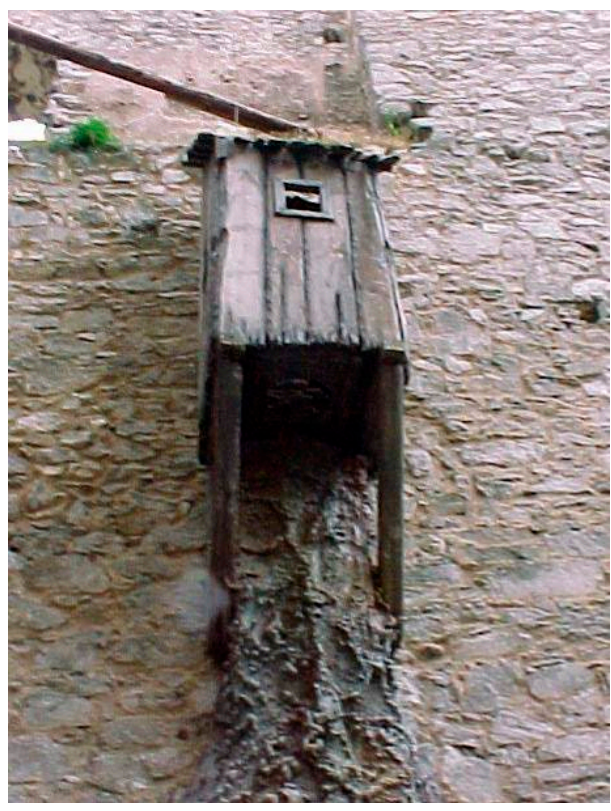

(b)

Figure 41. Exterior of garderobes: (a) Elaborated stone and brick construction at Burg Campen (Benutzer A., Wikipedia commons) and (b) Simple wooden structure at Kunta Hora Prague (G. Antoniou).

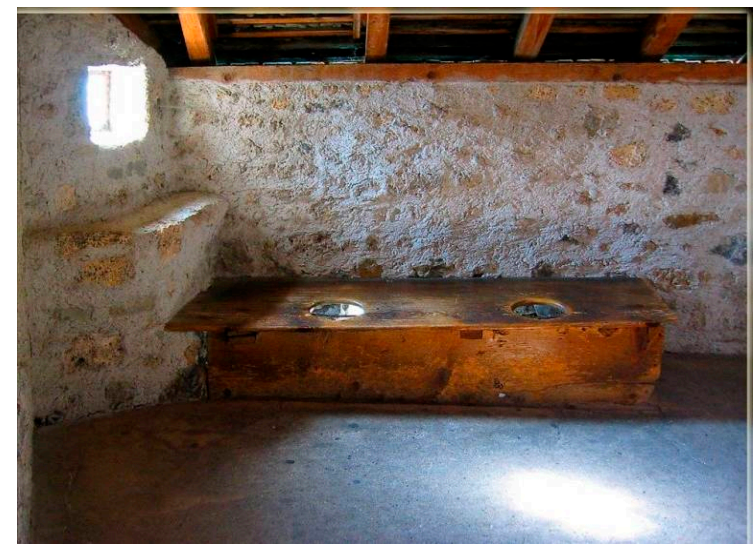

(a)

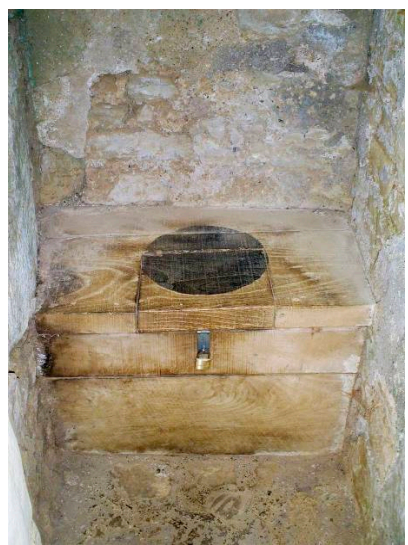

(b)

Figure 42. (a) Twin restored garderobe in Chillon Castle Switzerland (Eldar Kadymov Panoramio, [79-83] accessed November 2015) and (b) One of the garderobes at Bodiam Castle England (restored) (V. Tzekov, Panoramio, accessed November 2015) [79-83].

Garderobes had both stone (Figure 34a) and wooden seats (Figure 42). Most of the wooden restorations present a circular opening. On the other hand, there are surviving stone examples where the hole is not circular (Figure 34a,b, Peveril Castle, Drum Castle in UK as well) but a more anatomical shape for male users.

As far as it concerns the small domestic lavatory, the common type of the middle ages and the subsequent centuries can still be seen in some rural areas of our times. For example, in England this type of toilet remained in use even in the late 12th c. AD [94] (p. 143). That latrine installation was formed by a small wooden throne with a seat having a central hole located above a cesspit and with a small window in the door to keep the installation ventilated [95] (p. 539). It was usually installed in the garden of the house and could be built from brick. Actually, the Pompeian latrines tradition could be considered as a kind of prototype of this simple latrine. 
The location of a latrine as a sort of a cage fastened to the wall was a common practice in the military architecture, the typical garderobe as was discussed earlier. In the domestic cases this construction was simple and comfortable, especially in the dwellings located on a hill and surrounded by water, as the filth thus fell outside the enclosure or on its wall, providing an unpleasant sight but avoiding the accumulation of waste within the fortification walls. The privy box was constructed of brick, wood or of both materials. This type of latrine was common throughout Europe, and because of its prominence in the wall often served for defensive purposes, i.e., to observe the enemy's approach.

Apart from the latrines they also had cesspools. Within the medieval and post medieval towns there were latrines, from where waste was evacuated directly to the street. Citizens tried to build latrines at the greatest height possible, which, according to our reasoning is quite paradoxical [96] (pp. 264-265). For example, the parliament of Normandy in 1519 ordered the placement of the privies at the top of the buildings [97] (p. 38). This same construction, that is, the latrine located at the height of the second floor of the house, was usual in other cities too. Similar constructions survive even nowadays but are equipped with drain type sewers.

In the engravings of Albrecht Dürer we can observe the reality of the German and Italian cities of the late fifteenth and early sixteenth centuries-the walls of houses and city walls were littered with small boxes, fulfilling the role of latrines, where all filth fell to the street, or in the best case, outside the city walls. The latrine-boxes protruding from the houses were equipped with seats with a hole, from which the filth fell into a ditch or a channel expressly filled with ash [98] (p. 14). The same situation was common in the cities of England [99] (p. 26).

Stone built seat toilets related to that era survive in many other Castles as the twin lavatory, at the Aragonese Ischia Castle in Italy (Figure 43a). On the other hand it seems that in the east, where the Muslim tradition related to religious rules about defecation (anal) hygiene was-and somehow still is—strong, the squat toilet was predominant, as the one in a-possibly-later example in Sanaa, Yemen (Figure 43b). The squat type has been incorporated also in non Muslim constructions as the crusades toilet of Figure 36. These medieval semi squat formations could be relevant not only to the Seljuk examples-as in Aksaray Han, discussed in 6.4-but also to a mid 15th c. multiple toilet at a refuge in the Castle of Mytelene, Greece.

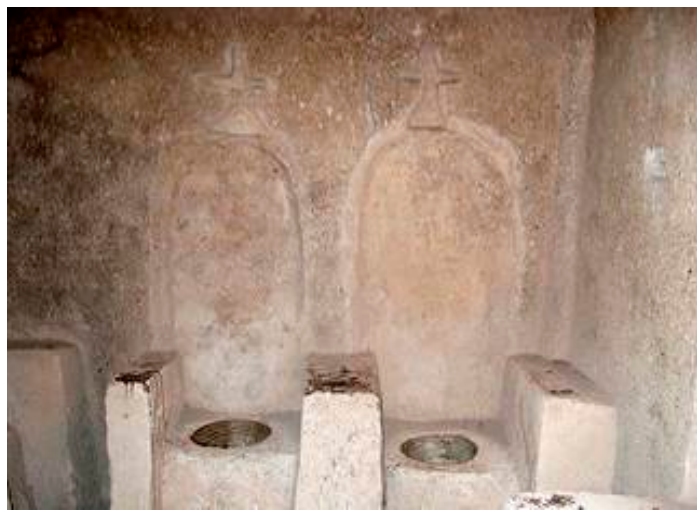

(a)

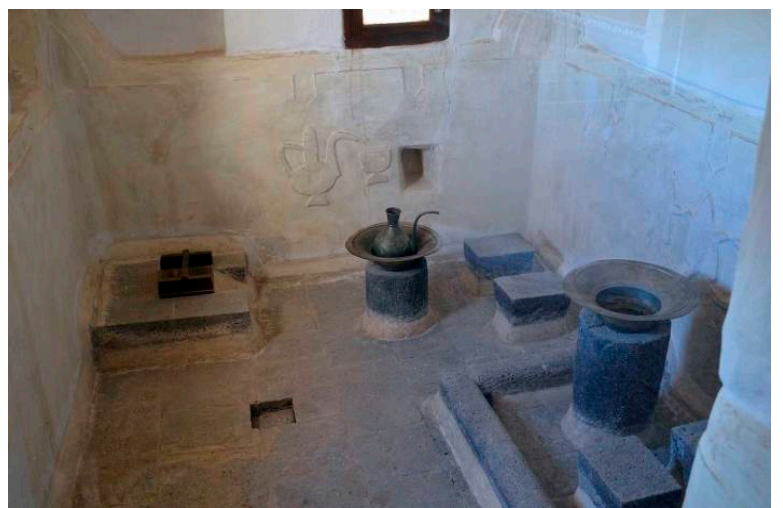

(b)

Figure 43. (a) Twin built lavatory, Aragonese Ischia Castle, Italy [100] and (b) Bathroom with squat toilet and bath in Sanaa Yemen [101].

\subsubsection{Latrine in Medieval Muslim Spain: Al-Andalus (8th-15th c.)}

The latrine constitutes a distinctive feature of the Andalusi towns. Like a twisted entrance that reveals a search for privacy, so evident in the Andalusi domestic architecture, the latrine is one of the elements that are present in almost all the houses. This is even more striking when comparing other European urban areas of the same time or the Spanish town sanitation after gradual shrinking and final 
disappearance of the Andalusi dominion at the end of the 15th c. For an illustration we can take the case of Cordoba in the Modern times. If the major residences maintained in some cases the latrine, most possibly as a direct Andalusi heritage, the houses of common citizens lacked any sanitation equipment. Therefore, a register shows that from 300 houses in the late 15th c. only three of them had a latrine [102] (pp. 151-152).

Normally, within rural settlements, the major part of the houses had no latrines and only some of the houses had their latrines connected to cesspools. Nevertheless, such vastly excavated Andalusi urban settlements as Siyasa (Cieza, Murcia) and Saltes (Huelva) or the suburbs of Caliphal Cordoba among others make evident a most common solution of medieval sanitation consisting in latrines connected to cesspools. It must be noted that in the towns where latrines connected to cesspools were employed, a separate channel evacuated rain water from the courtyard, which often fell over the streets. The inexistence of the connection between a cesspit and a drain water channel is therefore obvious since cesspools would have overflowed during the torrential rains [103].

Cesspits were usually located in public streets or cul-de-sacs. The location of cesspools outside the house was naturally intended to prevent the spread of bad odors and to preserve the cleanliness of the house. From time to time cesspools had to be cleaned, although this labor must have been quite unpleasant not only for those who carried it out, but also because it caused bad smells and pollution around the work place, normally a public street or a cul-de-sac. Cesspools were normally attached to the façade of the house in order to have the shortest distance between the latrine and the cesspool. Such settlements as the Caliphal suburbs of Cordoba are the clearest example of abundant cesspools located in the streets. The latrine and the pit were connected by means of small channels made of ceramics, stone slabs or bricks. Pits were sometimes paved with stones, covered with a stone lid or possibly with a wooden cover and leveled with earth [104].

The objective was to shorten the distance between the cesspit or a sewer and a latrine forced to place it near the entrance to the house, as close to the street as possible. Access to the latrine was usually located from the patio or the hallway (zaguán). At times the small size of the houses forced the owners to search for more ingenious solutions, such as placing the latrine under the vault of the staircase.

As it can be observed through the archaeological data, in an Andalusi house the privacy and the intimacy were key aspects while the latrine was being used. Apart from curtains and doors, the privy was often concealed by a low wall that created a curved entrance (entrada en recodo) and impeded viewing the person that was using the toilet by anyone who would have approached the entrance of the room.

Normally, a latrine was an extremely reduced space. Only several of the documented latrines were quite spacious. The major part of the Andalusi latrines can be considered as rather uncomfortable because their size was only $60-75 \mathrm{~cm}$ in width and $1 \mathrm{~m}$ in length.

A small rectangular platform of very distinct dimensions made of brick or stone, or marble, with a narrow opening in the middle was placed in the latrine room. A person would have had to squat in order to relieve himself. Sometimes the platform of the latrine was raised with respect to the floor level, a feature that may have contributed to keeping the room better ventilated. Nevertheless, latrines in various settlements present no podium such as in the case of the Siyasa settlement [104].

A small latrine room needed to be somehow ventilated. Most likely, slim apertures in the upper part of the wall were used to ventilate the room. Due to the orifice in the wall, the air would circulate freely from the patio to the street as the entrance to the latrine was normally from the patio.

Although the latrine was considered as dirty, unpleasant and, at the same time, the most intimate space of a house, some of the latrine rooms were decorated by means of mural paintings and exquisite pavements. The royal palace of Alhambra (Granada) serves as a perfect example of the sophisticated architecture under the Nasrid kingdom that would reflect itself even in the splendid latrine spaces. Rich mural decorations in lavatory spaces are also found in other remarkable dwellings in Seville and Cordoba and in the palatine town of Madinat al-Zahra (Cordoba, Figure 44) [103,105]. Similar elongated formation exists also in Japan, see Section 4.2. 


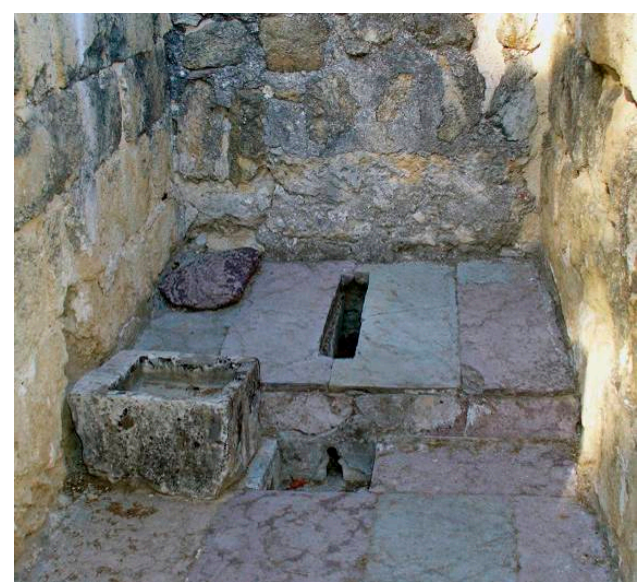

Figure 44. Muslim Medieval latrine from Madinat al-Zahra settlement, Cordoba, 10th c. (courtesy of I. Reklaityte).

Finally, it should be mentioned that apart from the more extensive use of cesspools, a sewerage network was present in some medieval Muslim cities of Spain; the presence of sewers is documented through archaeological excavations and written sources. In an overcrowded town, a sewer system implied a notable hygienic improvement.

As a result of the archaeological excavations, the town of Murcia offers an excellent example of a sewer network assembled in order to evacuate rain and waste water. Other Medieval Spanish towns, such as, Lerida, Denia, Malaga, Cordoba, Almeria and Algeciras also had sewerage networks of greater or lesser importance [106] (pp. 401-412); [107] (pp. 231-246).

\subsection{The Ottoman Practices Regarding Lavatory Installations}

The expression of Ottoman technology regarding the use of water has been evidenced in many architectural works all over the Empire. Meanwhile, the Koran mentions the use of flowing water for ablution before prayers, as well as for total cleansing of the body in the baths [108] as stated in Surah $\mathrm{V}, . .$. when you get ready for the worship, wash your face and hands up to the elbows ... [109]. It is therefore justified, that the cleaning procedure is closely related to the holy book of Islam and its prescriptions.

By the time of the urban expansion of the Islamic cities, as well as the Turkmen tribes began conquering the lands in western Turkey and in the Balkan peninsula, matters such as latrine technology, wastewater and sewage networks were already taken notice of and it is quite possible, that pre-existing solutions of such infrastructure continued to be in use all over the Islamic world. Ottoman archives mention the existence of imperial commands or court records regarding water lines and the distribution of water, that the specialized technicians or architects, enrolled in this task, were obliged to follow (named as suyolcu or abrahçi). 


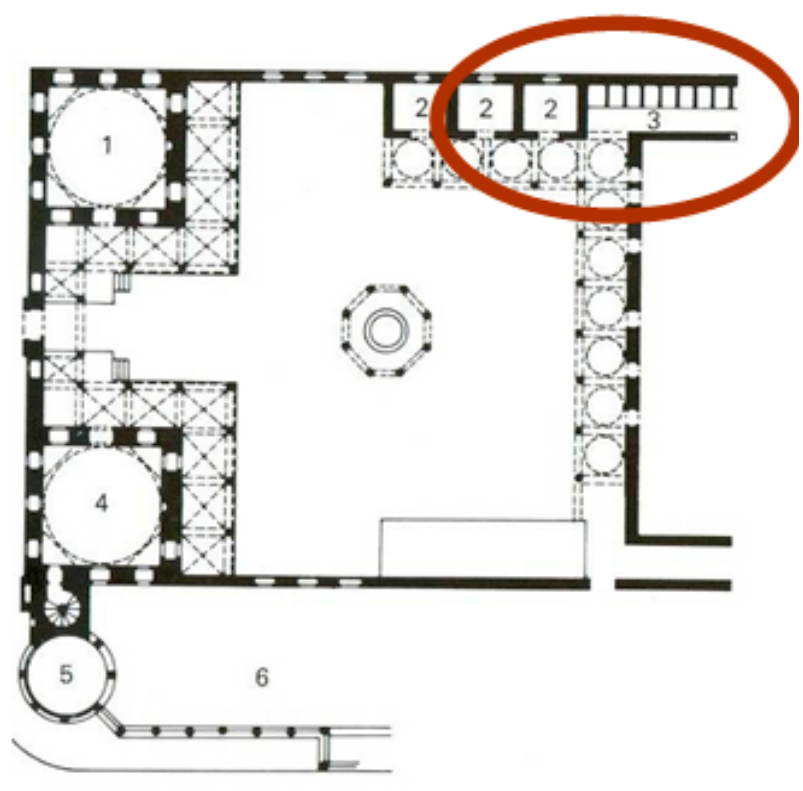

(a)

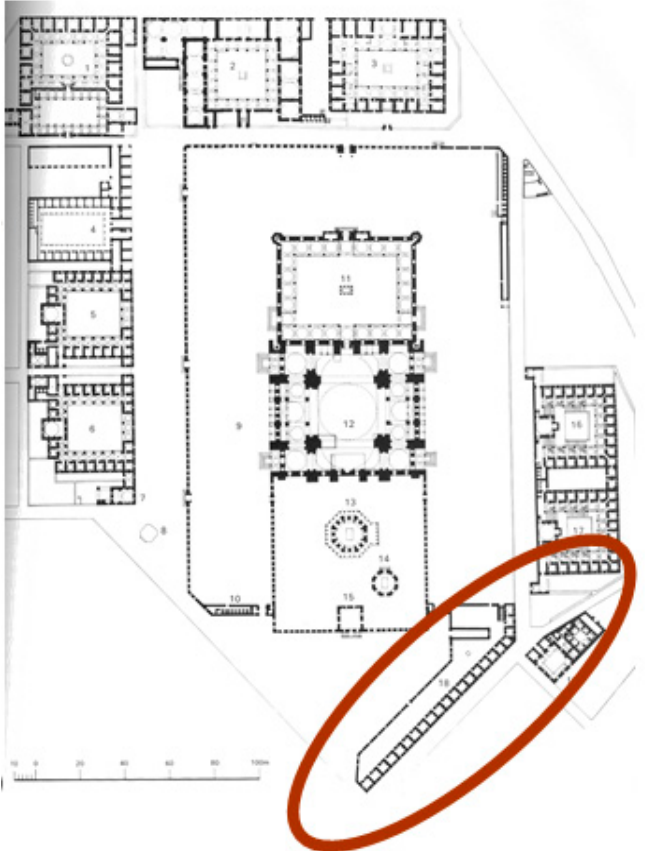

(b)

Figure 45. (a) Nevşehirli Ibrahim Paşa Darül-hadis, Istanbul and (b) Súleymaniye complex, Istanbul (both adapted by [110], (a) p. 370, (b) p. 217.

As new urban centers were founded, but also in cases of formerly established cities that were conquered by the Muslims, many new buildings were constructed to fulfill the needs of the Islamic societies, and therefore religious buildings, as well as secular ones, but also mansions of domestic use, appeared. Most of these constructions were financed with the help of the Vakif institutions that also enabled their maintenance [111]. Sanitary installations (toilets) can still be found in Ottoman secular buildings (as represented through the architectural types of mosques, medreses (i.e., Nevşehirli Ibrahim Paşa Darül-hadis, Figure 45a), hammams, thermal baths (kaplıca), or külliyes-complexes of mixed uses, etc.), and two layout composition plans are traced. In the first case, as a mosque formed part of a whole complex (such as the Súleymaniye complex in Istanbul, Figure 45b), lavatories were located in a rather remote part of the court.

Additionally, in cases where the mosque had no exterior courtyard, public toilets were inserted in the structure as an independent unit. Also in cases of smaller mosques (i.e., Húdavendigar cami, Bursa, Figure 46a) or other types of buildings (such as the Çinili kiosk, Istanbul, Figure 46b), lavatories were incorporated in the general ground floor plan of the building [112].

Squat toilets were used, and placed adjacent to each other. Partitions were constructed, in order to offer some kind of privacy. This characteristic feature was lacking in relevant examples (sanitary installations) of the ancient Greek and Roman lavatories' scheme, as well as centuries later, they had a layout similar to those of the Seljuk Hans.

The 13th c. Seljuk Caravanserais in Anatolia were equipped with lavatories for public communal use, which were sometimes attached to the bath. An exception was that of the Aksaray Sultan Han on the Konya-Aksaray Road (Figure 47) [73], where the water installations run along the west exterior wall of the courtyard and the collective lavatories are situated at the southwest corner. The channel that facilitates the sewage is still evident. Single toilets are also traced as private small cells in the baths (hammams) of the caravanserais.

In cases of the public balnear buildings (hammams), small rooms -toilets for single use-formed part of the disrobing hall (i.e., as noticed in Figure 48a,b) and were placed close to other auxiliary rooms (i.e., the depilatory room) instead of being located outside of the building. 


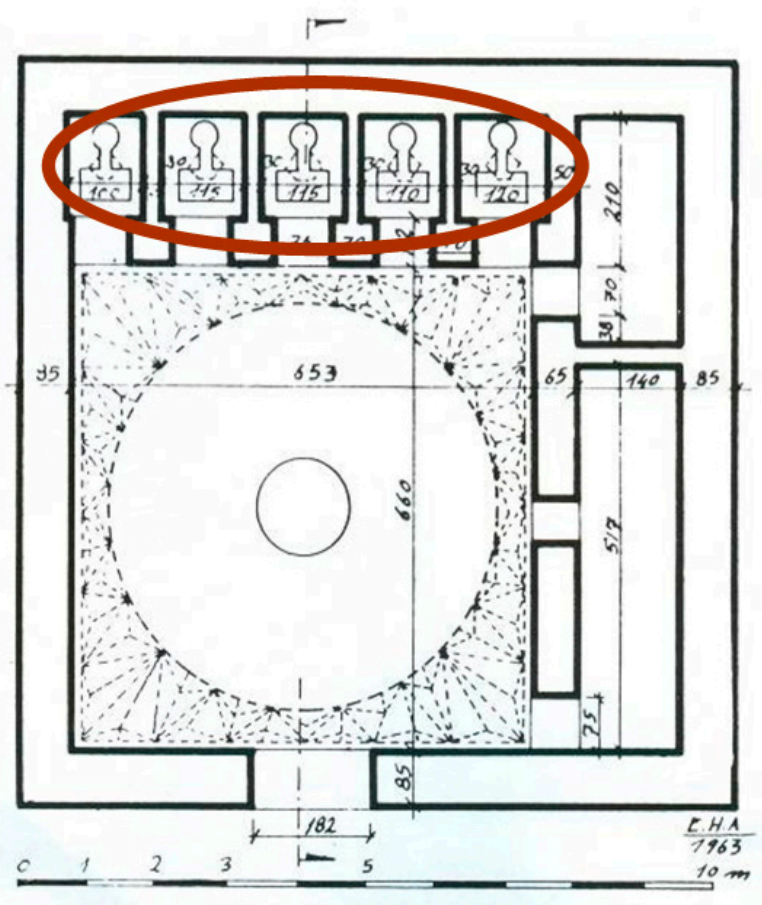

(a)

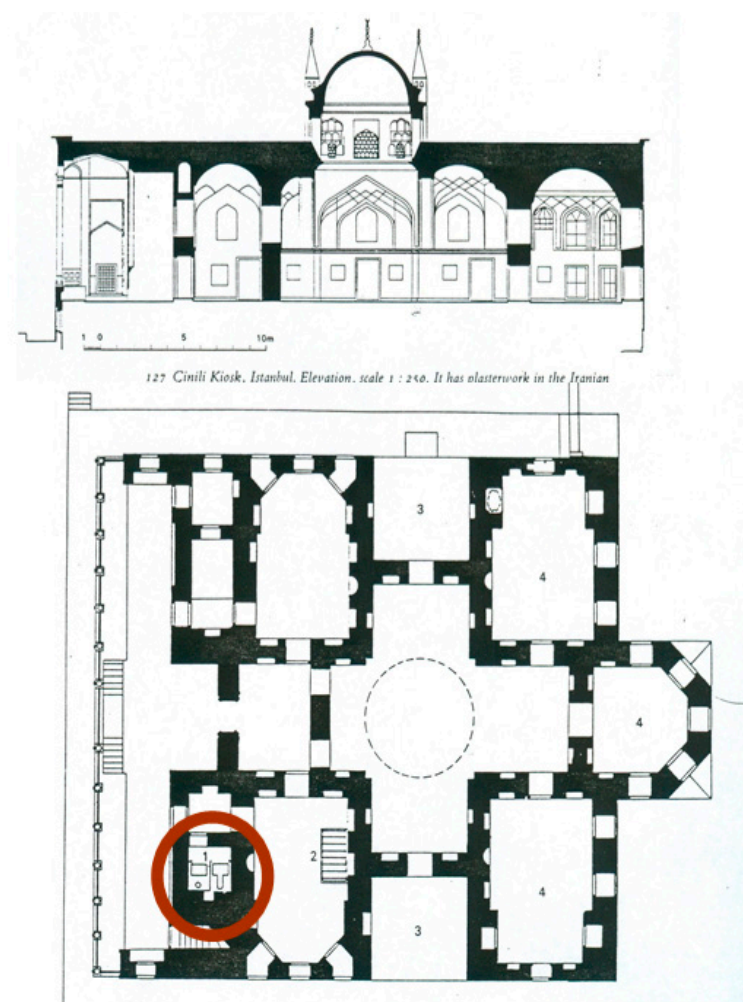

(b)

Figure 46. (a) Hûdavendigar cami, Bursa (adapted by [113] p. 260) and (b) Cinili Kiosk, Istanbul (adapted from [114] p. 136).

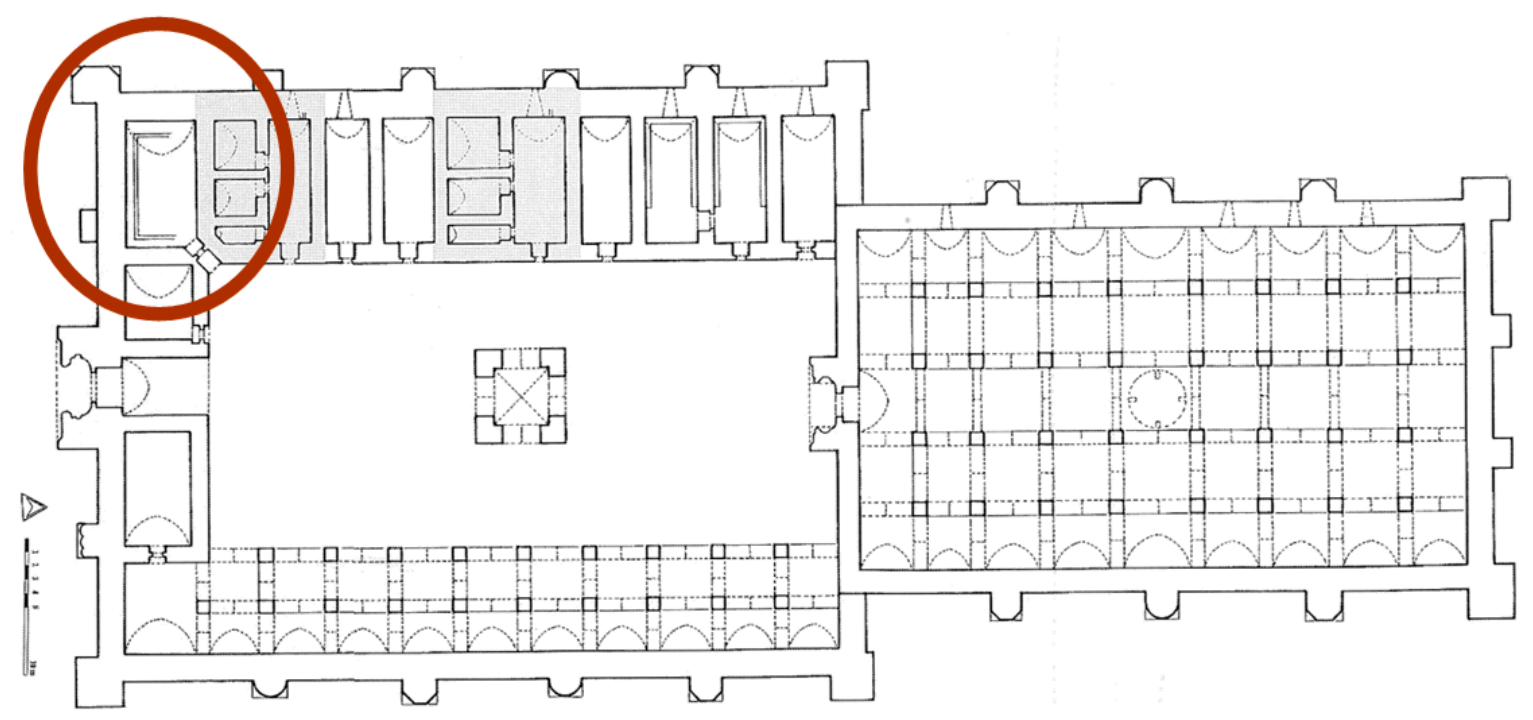

Figure 47. Aksaray Han, Konya (adapted from [73] p. 120). 

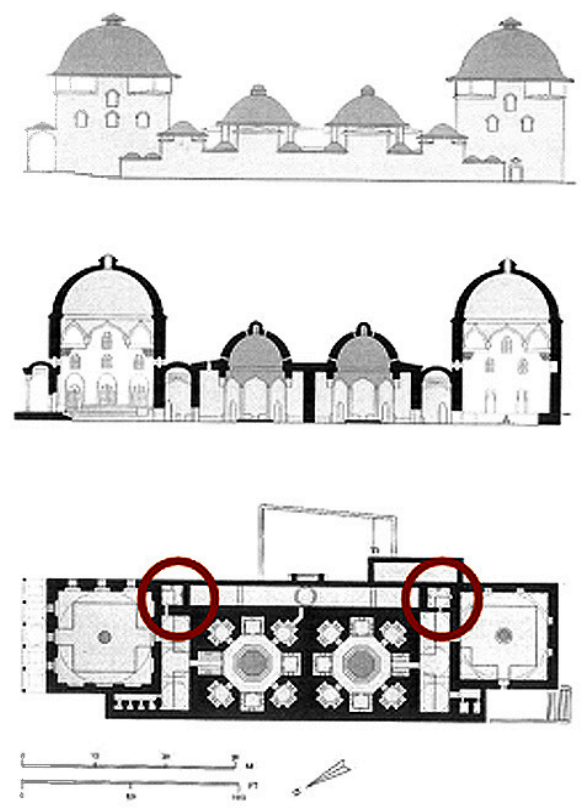

(a)

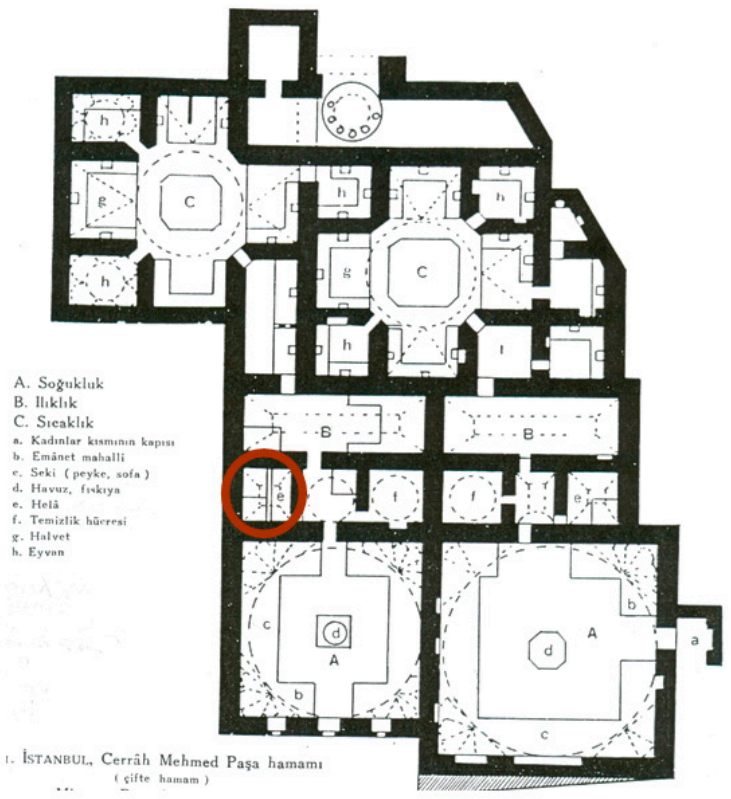

(b)

Figure 48. Hamams: (a) Haseki Hürrem Hamam, Istanbul (adapted by [111] p. 249) and (b) Cerrah Mehmed Paşa Hamam, Istanbul (adapted from [115] p. 253).

The floor of the latrines was usually paved with marble slabs. A key-shaped hole was opened in the centrally placed slab (elaborated with an inclining surface) for the human waste. The specially curved slab was set at a distance from the wall, as the user's body should not come in contact with the human waste, while the wall's vertical surface formed a convex profile, in order to avoid splashing.

Several marble slabs used for the squat toilets were often well elaborated, as it can be noticed in many examples. The toilet slabs exhibited in archaeological sites such as the Bodrum castle in southern-west Turkey are a good example, (Figure 49). Also in situ Ottoman squat toilets slabs were located on the lower row, e.g., at the Castle of Mytelene, Greece illustrated in Figure 49, lower row.

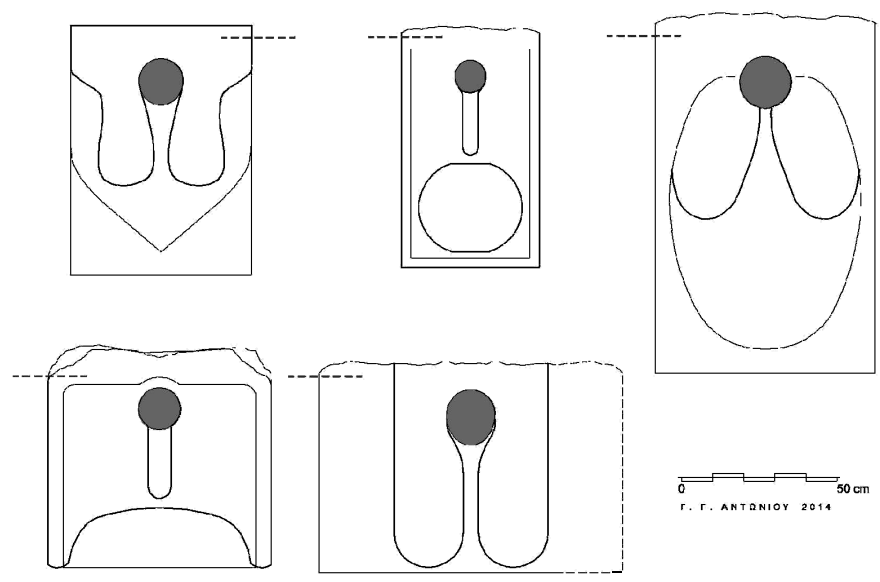

Figure 49. Ottoman squat toilet slabs. Upper row: exhibited at the Castle of Bodrum, Turkey and at the lower row: in situ at the Castle of Mytelene, Greece (courtesy of G. Antoniou). The dashed line indicates the outline of the wall.

Toilets were not equipped with a flushing system, but were cleaned through a full ewer (which is a water jug) inside the cell. Fresh water was supplied from the nearby fountains or wells by ewers. 
This was a special duty of the employee responsible for cleaning the lavatory (Figure 50). Human waste was removed from the toilet through ceramic pipes, and placed under the key-hole shaped slab. In the 18th and 19th c. these slabs were formed in an elaborated manner (Figure 49). Latrines were illuminated by small openings set on the roof, which also enabled the necessary ventilation of the cell.

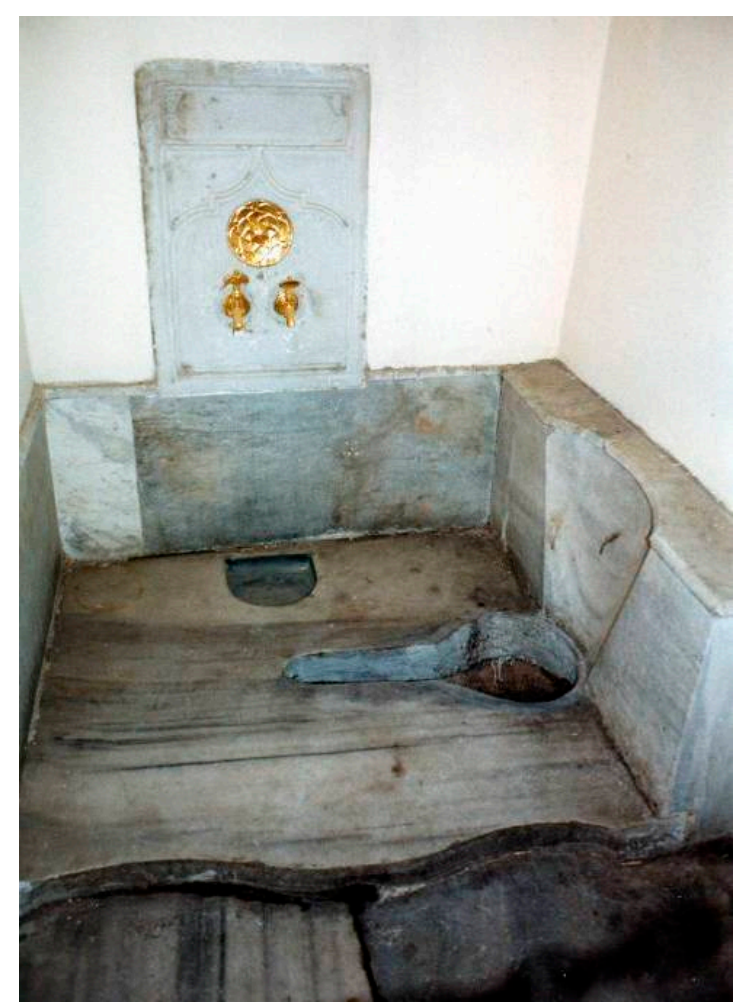

Figure 50. Lavatory at the Harem, Topkapi, Istanbul (courtesy of E. Kanetaki).

Lavatories (toilets) were also one of the necessary installations to be found in domestic architecture: they were situated outside of the buildings and as they were usually made of poor materials, almost no traces have been surveyed in houses dating from these times. The lack of hygiene conditions in domestic architecture was one of the main reasons for which the ritual of the hammam (public steam bath) became so popular [116].

As Muslims are supposed to perform ablution five times a day, the residential buildings provided a special area and facilities for it, the Güsülhane (ablution closet). Houses usually had no bath inside the main building, instead a single, independent unit, incorporating the bath, the kitchen, and a fireplace was constructed in the garden courtyard [117]. The stone-built mansions with timber stories of Safranbolu in Anatolia though, (as well as other nearby villages, such as Yürükköy), present a different solution, as washrooms (abdestlik) and lavatories (hela in Turkish, toilet), were located usually on the middle and upper floors, enclosed in one unity, and separated by a door. Lavatories were situated away from the main rooms, while small windows at their "blind" sides allowed some kind of ventilation. The wooden floor of the washroom-WC had a triangular hole with raised edges, connected to the sewage pit through a vertical drain. Otherwise the space beneath the hole was empty and waste matter used to fall into a pit, lower into the ground (this is why lavatories of the middle and upper floors are not situated one over the other). In other cases, floors were paved with marble slabs (i.e., Figure 51a,b), while the key-hole shaped defecation opening could be flanked by footrests (as shown, partially, in Figure 50). A ewer of water (water jug) was always used in the toilet for cleaning purposes. 


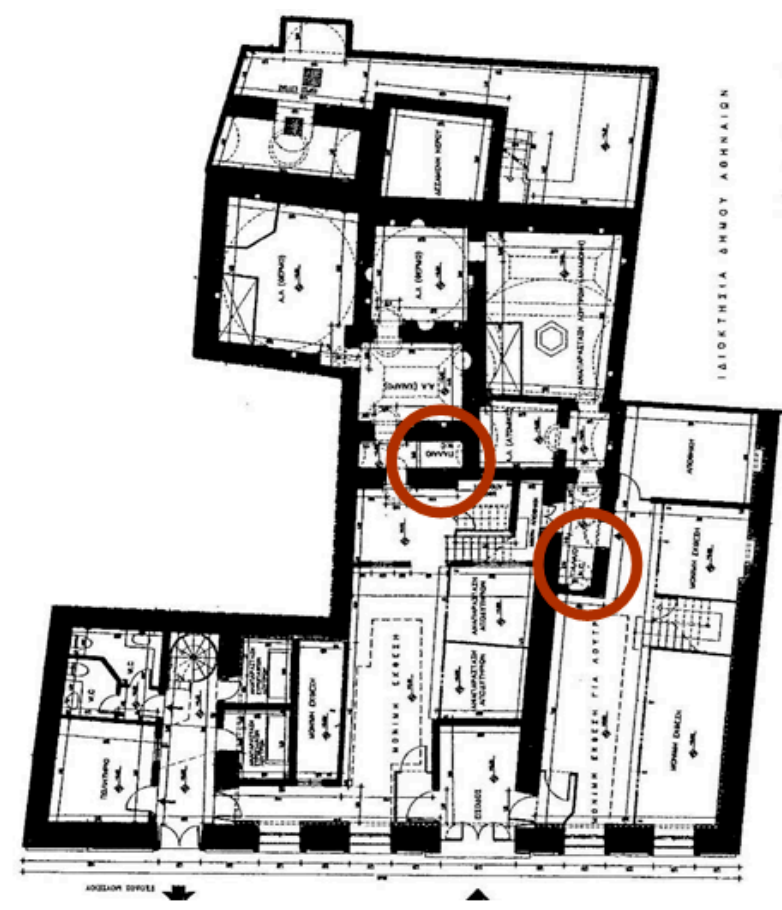

(a)

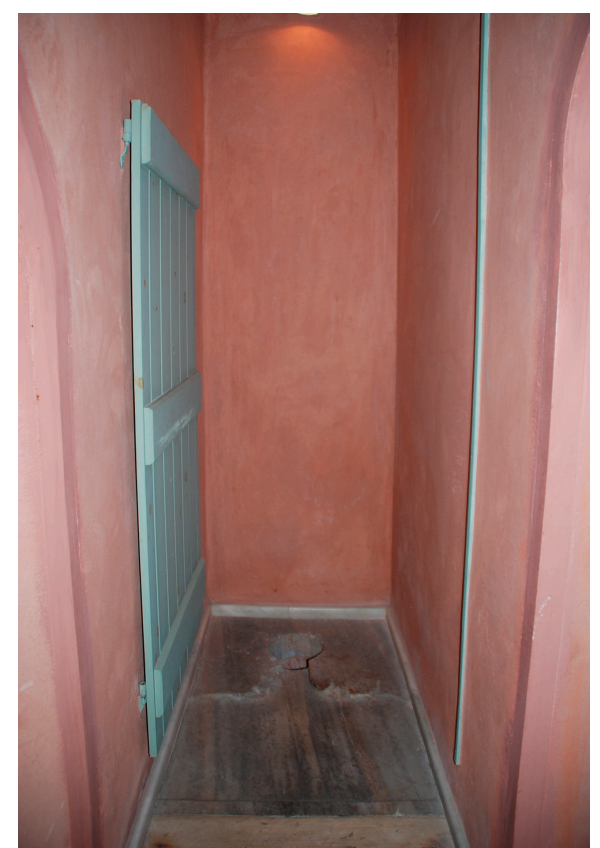

(b)

Figure 51. Bath of the Winds (Loutro twn Aeridwn), known also as Abid Efendi Hamam, Athens, Greece (a) Plan ([116], p. 216) (b) one of the squat toilets (courtesy of E. Kanetaki).

\section{Late Chinese Dynasties}

The construction of toilets was becoming fastidious after the Han dynasty. Toilets during the Jin dynasty (ca. 265-420 AD) were known as Ce or Hun (toilet), Qing (latrine), and Xuan (small room or changing room). Ce (则) means the toilet must be built at the side of a house or other private place; Hun (溷) means that the toilet usually connects to the pigsty for the purpose of mixing the human and the pig ordure for fertilizer; Qing (圊) or 清 means the toilet should be clean and sanitary; Xuan (轩) or the changing room are adopted to describe the fact that the build of toilet is fastidious. Furthermore, celebrities and nobilities in the Jin dynasty preferred the luxury life, so much effort was spent in decorating the toilets. Thus, they not only incensed the toilet with fragrance, but also had special servants to serve the toilet users. In addition, for the upper class, to change clothes after using the toilet was quite popular at that time. According to the New Words of the Day (世说新语), it was often described that if the gentlemen and rich men attended a feast, they should change into to new clothes prepared by the host in the toilet; and if one says "going to the toilet", then it means "to change clothes"; therefore the toilet was known as a "changing room" [118].

After the Han dynasty, private toilets were usually built in the private locations of the house or a place near it. As long as they were built within a house or a courtyard, the toilets must be built in a shady location, but not directly facing the main gate. The design of the toilets also illustrates the principle of privacy. The latrines of public toilets were often divided by short walls. Private toilets were usually built with high walls and a door. In the Tang dynasty, houses were mostly in quadrangle dwellings (617-907 AD), in which the kitchen was built on the east side, and private toilets were located at the back of the house or connected to the pigsty [118]. The ancient times considered the differences between male and female and the rules between superiors and inferiors. Whether public or private, the toilets were divided into male or female, nobility or servant, and host or guest [119]. Instructions by Si Maguang of the Song dynasty (960-1279 AD) states that the construction of palaces must pay attention to the usage indicating that hosts and guests, and males and females cannot use the same toilet. 
To facilitate the collection of excrements, people were busy building toilets. In towns or rural villages, public and private toilets existed. Public toilets were classified as general public toilets or central public toilets. The latter were on a large scale, with the function of storing the excrements collected from the general toilets. The management of public toilets and the collection and sale of excrements was operated by the excrement factory. The collection and sale of excrements of the private toilets were operated by the excrement man. The excrement man delivered and sold the wooden bucket filled with excrement to the excrement factory. In addition, the newly collected excrements or dry excrements were sold to farmers in the town. Since too many people were engaged in this business, strict regulations were set. During the Qing Dynasty (1636-1911 AD) in Beijing, a guild called the fertilizer association was founded by excrement men. The association stipulated that the excrement man must collect excrements along a specified road without trespassing, and they had to use specified procedures [120].

Private toilets in the Fujian province during the Qing dynasty were usually built within the house [121]. However, those toilets looked like a tall wooden cabinet which could accommodate one or two persons. The cabinet was placed off the ground about 0.90 to $1.20 \mathrm{~m}$, and a clay pot was placed under it for collecting the excrements. A staircase was connected to the toilet from the courtyard. Hence, people closed the door when using the toilet, since others could freely pass through the courtyard. The dwelling houses of the Qing Dynasty were also found in Zhengjing. However, in the Jiangsu province the toilet in the back of house used clay pots for collecting excrements [122]. The wall of the toilet was made of rectangle bricks and the latrine and channel used for collecting excrements were built inside. Two elaborate toilets from Qing palace are shown in Figure 52.

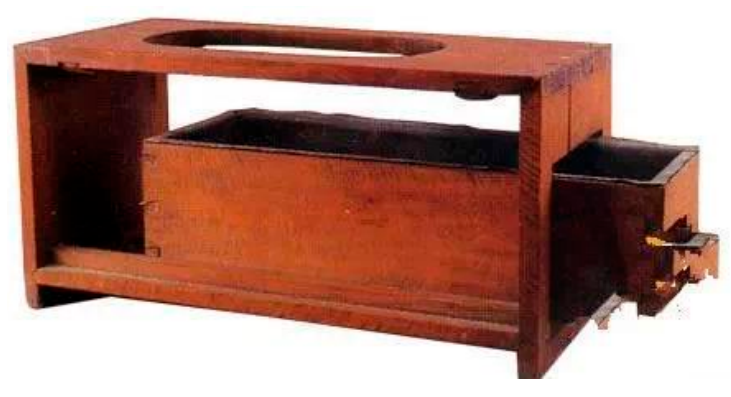

(a)

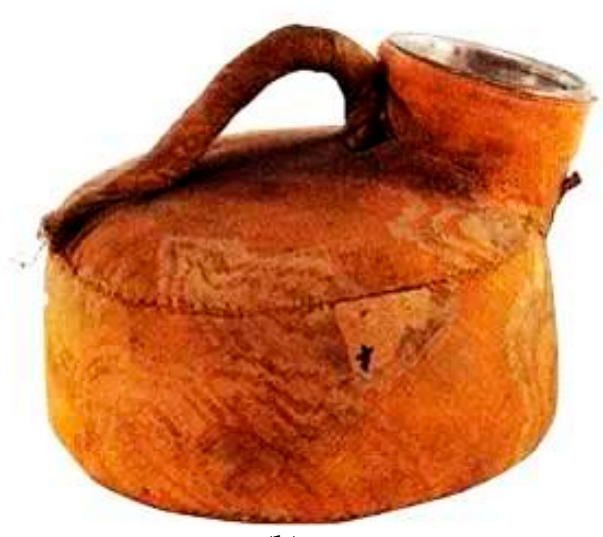

(b)

Figure 52. Two Qing Emperor's toilet from the Qing palace (Z. Xiao Yun): (a) rectangular type with waste removal part and (b) circular type with lid.

John McGowan, a British missionary, came to China in 1860, and preached successively in Shanghai and Xiamen. His preaching emphasized the building of toilets and the collection of excrements [123]. He wrote that the excrement was cheap and good, and is the best fertilizer for farming. In order to make money, people built toilets along streets, lanes, corners, and avenues from which they collected excrements each morning. People delivered the excrement to a central location for storage and transport.

\section{Modern Times}

\subsection{The Early Industrial Period (Late 18th c.-end 19th c. AD)}

Before the Industrial Revolution, the practices of the middle ages continued, but some items such as the closed or commode stools provided a portable solution. Like the chamber pots they were 
popular. The luxurious example of a commode stool is shown in Figure 53, dated from the mid 17th c., it is a relevant example of how the ordinary people used simple materials.

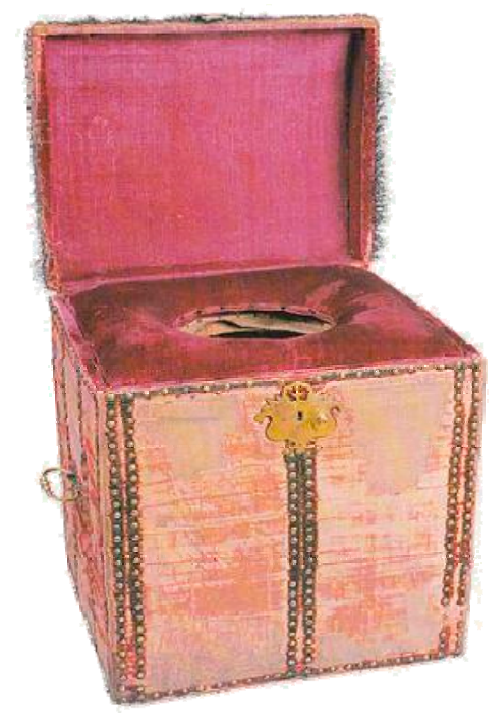

Figure 53. Commode stool from England dated in mid 17th c. (Wikipedia commons).

At the beginning of the Industrial era, organized efforts to improve the medieval technologies, particularly in England, resulted in the privy middens and later the pail privy closet $[124,125]$ in order to fulfill the needs of rapidly expanding industrial cities of that country. That concept combined defecation activities and waste disposal. The leakage to the ground-a problem already detected in early 19th c.- -and the pronounced difficulties to empty and clean such constructions led to the pail closet formations $[125,126]$ (Figure 54). Ventilation formations and the use of ashes were applied to reduce odors. Despite that, the tradition of the midden closet was continued and was incorporated as an improved formation (Figure 55) in relevant technical publications until the turn of 19th c. [124].

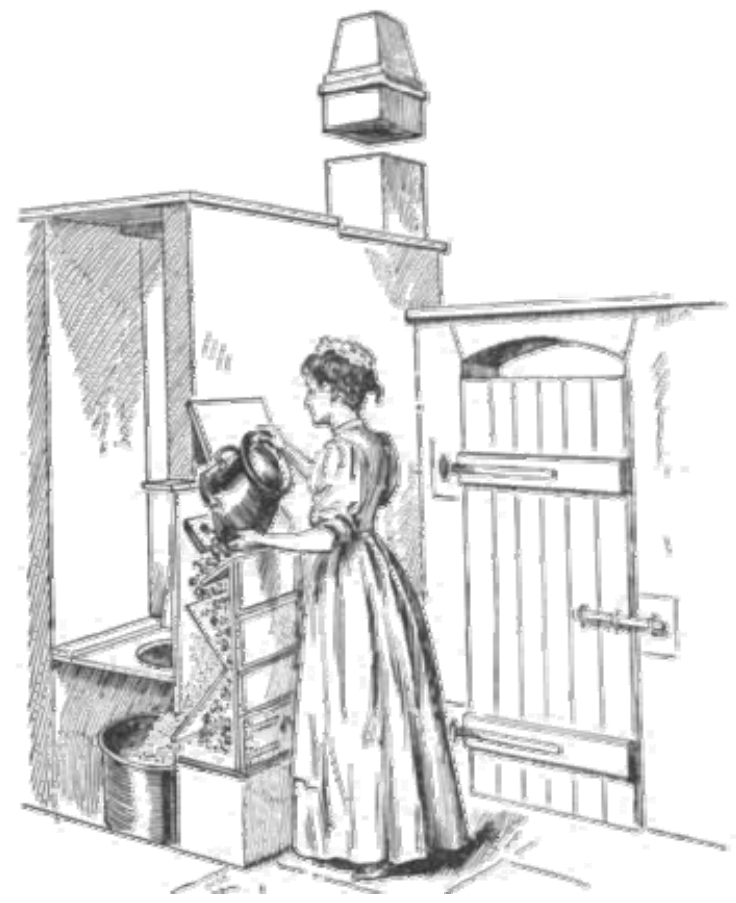

Figure 54. Pail privy with cinder-sifter. Absorbent pails with ashes were also used [124]. 


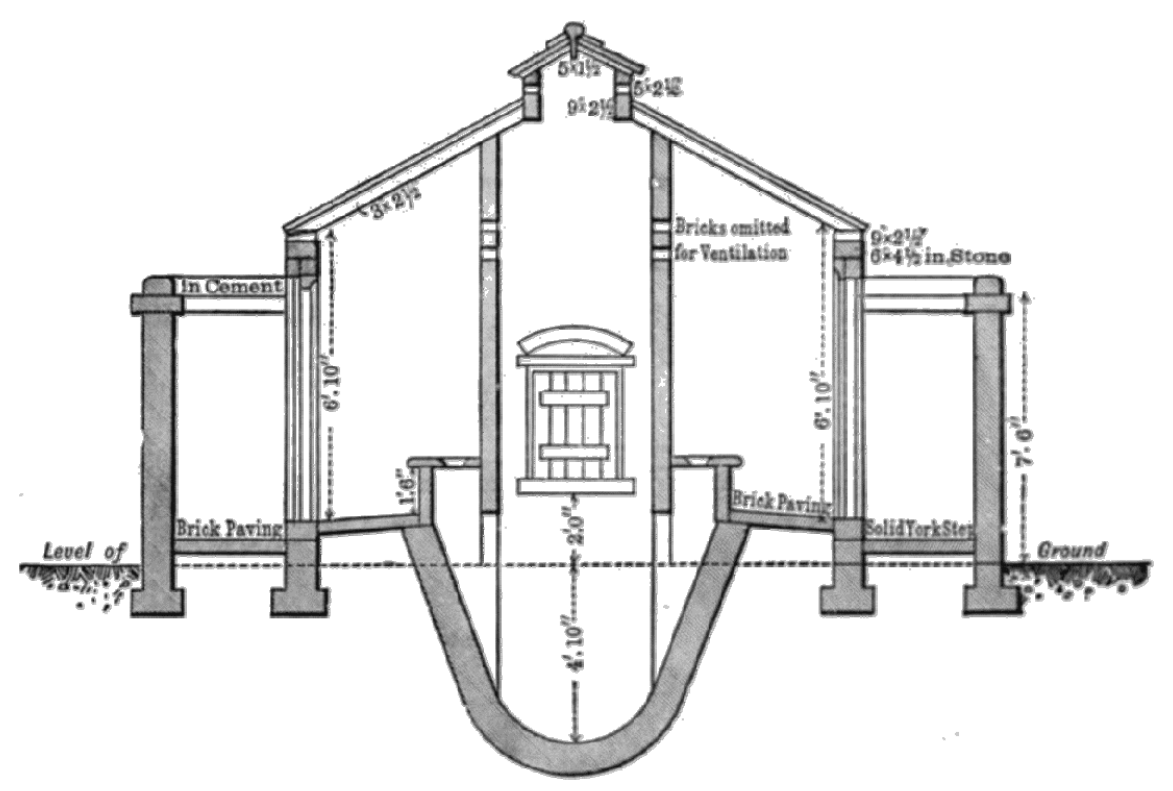

Figure 55. Improved midden closet in Nottingham. Cross section [127].

Sir John Harrington invented, in 1596, a device for Queen Elizabeth (his Godmother) that released wastes into cesspools, an early version of the modern-day toilets. Poor seals, however, caused odors to remain be a problem. Note that modern-day flush toilets have three basic elements: a valve at the bottom of the water tank, a wash-down system, and a float valve to fill the tank in preparation for the next flush. Harrington invented the first two. It was not until the late 1800 s that a plumber by the name of Thomas Crapper was able to enhance Harrington's idea, and that of Alexander Cummings [126], with the then-available industrial-age manufacturing technology to produce, on a wider scale, the forerunner of the modern-day toilet. This was accomplished in an age (the late 1800s) when the connection between human wastes and disease finally began to be understood.

Separate toilets for men and women first appeared in 1739 at a restaurant in Paris. In London in1775, Alexander Cummings (a watch maker and mathematician) made a version of a toilet that had a "trap", utilizing water as the seal, for keeping odors from coming back into the house. Still, it would be another hundred years or more before the "toilet" would be widely used. In 1778, the Cummings model was improved by a cabinetmaker named Joseph Bramah [127]. During this same time period, the earth closet was developed. Instead of water, earth was used as the flushing medium. Later pan closets came into being; they were operated like some cigarette ash trays-the bottom had a trap door which was opened to allow the wastes to fall through into a cesspit or cesspools.

Moreover, new problems have arisen such as the contamination of surface and groundwater. Naturally, intensification of unresolved problems led societies to revisit the past and to reinvestigate the successful past achievements. To their surprise, those who attempted this retrospective analysis, based on archaeological, historical, and technical evidence were impressed by two things: the similarity of principles to present ones and the advanced level of lavatories engineering and urine separation practices.

In some cases, in the first half of the 19th c., the familiar squat toilet was used even in mansion houses. The early 1850's squat toilet in a row at Hermoupolis Greece (Figure 56) at a wealthy mansion shows that these type of toilets continued not because of money shortages but due to habit. In that case the formation is interesting (if it is not a later impromptu modification) because it testifies a common use, like the ancient and medieval examples. The presence of that type of toilet is possibly related to the origin of the owners from Asia Minor. Even though their businesses were related to western Europe, they preferred the familiar oriental squat toilet type. 


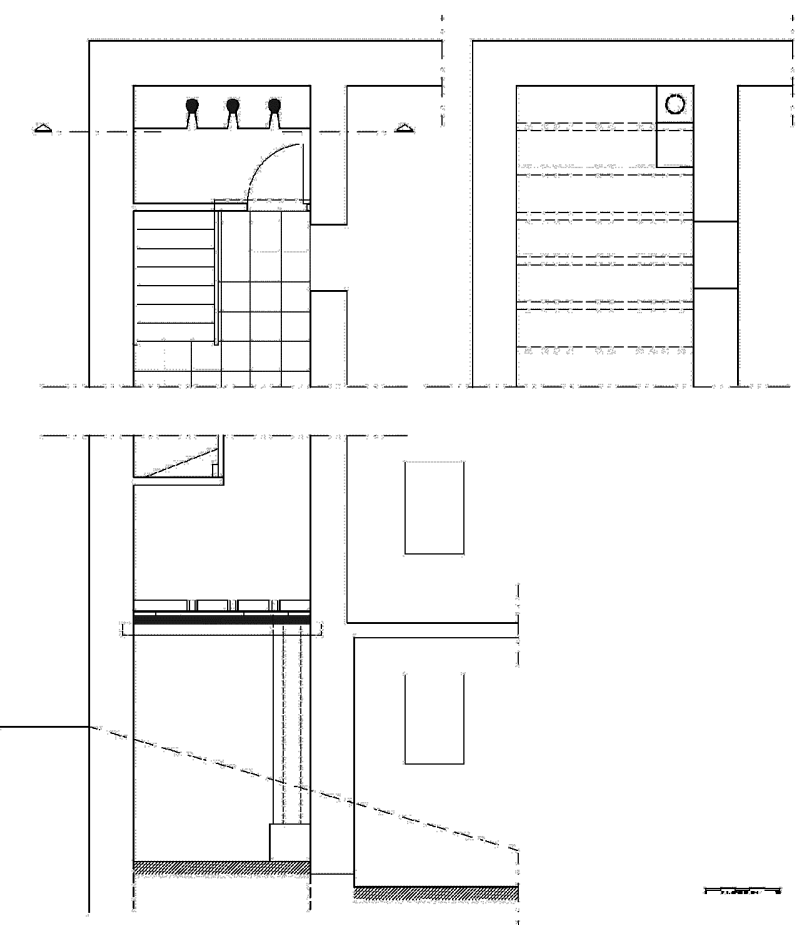

Figure 56. Plans (up left ground floor and basement up right) and cross section (bottom) of the toilet in the 1840's mansion house at Vaporia. At the section is shown also the vertical sewage (drawing by G. Antoniou).

It seems that the natural western habits with portable defecation vessels were common also in Japan incorporating the country's traditional skilful carpentry. That practice continued at least until the 19th c. (Figure 57a). Most probably this was a much earlier habit which survived until the modern times. It is worth mentioning that the squat position is predominant in the eastern cultures (Figure 57b). That habit was continued also there and the squat toilets are still being applied nowadays from Near to Far East for various reasons such as physical, hygienic and economical factors, and even due to tradition.

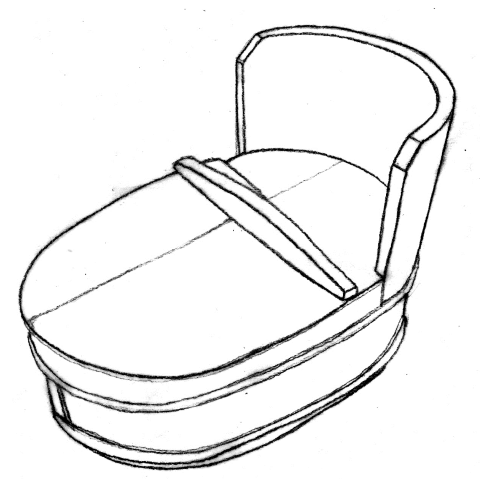

(a)

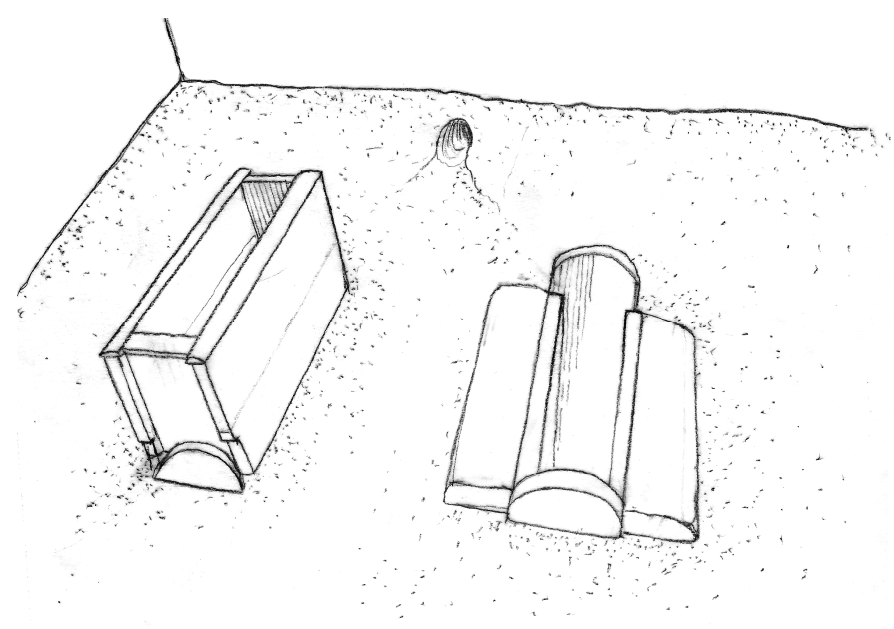

(b)

Figure 57. Japanese toilets: (a) Edo period (17th c.-mid 19th c. AD) wooden defecation vessel (G. Antoniou) and (b) wooden sitting and squat toilet (sketches by G. Antoniou). 


\subsection{Modern Times (Early 20th c. to the Present)}

During 20th c. the typical flush toilet became the predominant solution globally. Some years earlier important innovations had already been applied as the flushable valves, water tanks that rest on top of the bowl rather than above, and toilet-paper rolls. On the other hand, several countries and cultures continued the use of squat toilets for various reasons. In these early 20th c. years the typical toilet designs started changing from the elevated water tank into the modern toilet with a closed tank and bowl. In Figure 58 is shown a cross section of a building illustrating elevated water tanks for the flushing and the entire system of a modern (late 19th c.) residential building.

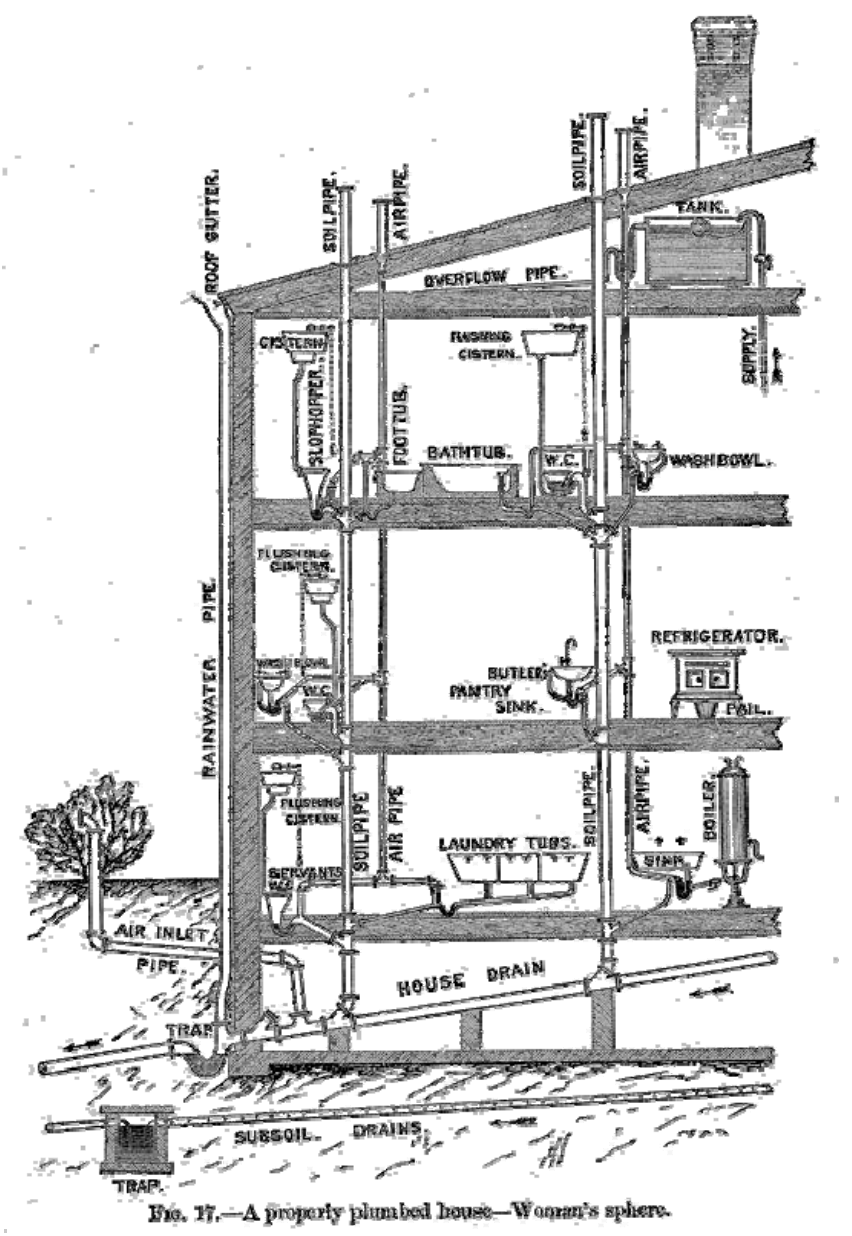

Figure 58. Woman's Sphere, illustration from [128], 1884.

In the Far East during the period of the republic of China (1911-1949 AD), the western flush toilet was introduced into China and generally in the Far East, but only for the urban population and wealthy households. The majority of the population, especially the rural population, still used traditional toilets. In recent decades, the flush toilets have been widely used by Chinese families. In cities and some rural areas, residential buildings consisting of large quantities of units were widely constructed, and flush toilets were built in every apartment. For those apartments taking up over $100 \mathrm{~m}^{2}$, all are built with more than one flush toilet. Some toilets are even equipped with high-class water jet devices that can clean the anus after using the toilet. Financed by the local governments, the public toilets have been built among streets and villages. To reduce costs of management, some of those toilets are operated by contractors. The sanitation of public toilets is conducted by the special government agencies. In addition, the hygiene agencies of government are responsible for checking the sanitation of public toilets. 


\section{Future Trends}

\subsection{Introduction}

In household wastewater and biodegradable solid waste, the main proportion of the plant nutrients are found in the toilet water (i.e., in urine and feces). In order to recover most of these nutrients, with the purpose of decreasing the emission of eutrophication agents and of increasing their recycling, present waste and wastewater systems have to be modified. If the urine and the feces are collected, up to $91 \%, 83 \%$ and $59 \%$ for $\mathrm{N}, \mathrm{P}$ and $\mathrm{K}$, respectively, can be recovered and recycled from the household wastewater [129]. Urine can be collected separately in a double flushed urine-diverting toilet and the feces separated from the flush water using two parallel Aquatrons. The Aquatron separates by a combination of a whirlpool effect, gravitation and surface tension. In this study, nitrogen and phosphorus from the feces were separated to $73 \%$ and $58 \%$, respectively, to the dryer fraction. The combination of fecal separation and urine diversion in the house Ekoporten made it possible to collect $60 \%$ of $\mathrm{N}, 46 \%$ of $\mathrm{P}$ and $43 \%$ of $\mathrm{K}$ from the wastewater, indicating that this method is an alternative when aiming to recover plant nutrients while still wanting to use water-flushed, urine-diverting toilets, although the potential to collect the nutrients is much higher [129].

Depending on the overall goal of the treatment process, a specific technical solution or a combination of solutions can be found to meet the requirements. Such combinations are not discussed in this paper as they are explicitly presented in the literature. Except for "evaporation" and "storage", none of the processes described have so far advanced beyond the laboratory stage. Considerable development work remains to be done to optimize urine-processing techniques in order to create marketable products.

Some of the important issues include: urbanization, decentralized water supply and sewerage systems. In addition, the major global water and wastewater challenges are:

(a) population growth and urbanization including growth of small/medium size unplanned towns

(b) use/consumption

(c) competition between sectors

(d) energy

(e) climate change and/or variability

(f) aging, deteriorating or outdated critical infrastructure

Moreover, the world in 2050 could face (data from IWA):

(a) 2 billion more people $(\sim 145,000 / d)$

(b) $90 \%$ of this growth in developing countries

(c) more than $80 \%$ of this growth in urban areas

(d) $2 / 3$ of countries with water scarcity (1/3 in 2000)

(e) flood risks

\subsection{Toilets}

The expected increase in urbanization will have serious impacts on the future wastewater management and especially to sanitation infrastructure including toilets. New types of toilets should be developed and adapted to the new environment.

(a) Vacuum toilets. Vacuum toilets should be further improved especially for locations with low water availability. Hamburg is a good case of 30\%-50\% savings of potable water in houses using vacuum toilets (Figure 59). 


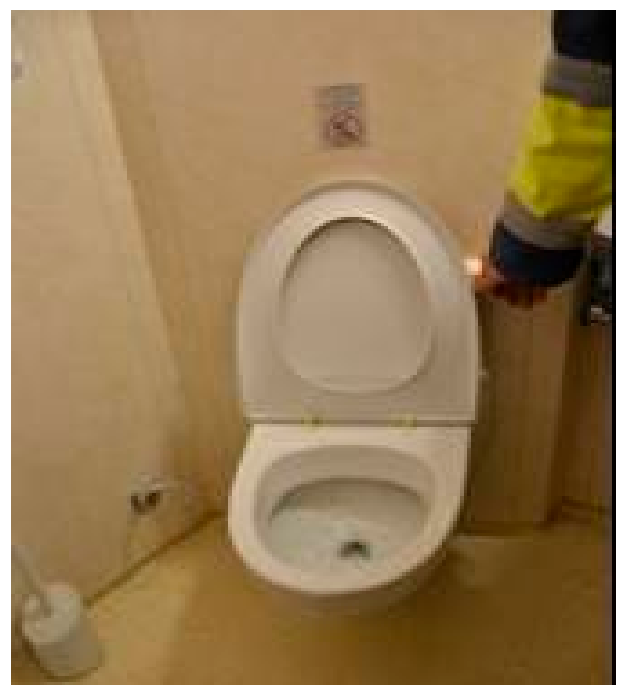

Figure 59. Vacuum toilet (with permission of A. N. Angelakis).

(b) Urine separation. Techniques for the separation of urine from the raw wastewater at the source of its generation have been applied for thousands of years in different parts of the world. The reasons for this vary, and the system solutions vary too [127]. In China, for example, the objective has been to reuse the nutrients present in human excreta. Urine is separated in simple toilets and collected for use as fertilizer. Elsewhere, the main reason for urine separation has been to obtain a dry, manageable and hygienic fecal fraction. In Yemen, for example, urine is separated in simple toilets and trickles down onto an outside wall where it quickly evaporates in the warm climate [130]. In Shibam, Yemen the toilets had two outlets: a front outlet for urine and a back outlet for feces. Both have been carried down by gravity, the liquid from a pipe (to agricultural fields) and the solid from a shaft, to the collection baskets, since $750 \mathrm{AD}$ [131].

Marino's urine-separating toilet (Figure 60) was thought to have solved the hygienic problems of Danish and Swedish cities in the mid-19th c. Its design was very similar to that of today's urine separating toilets (Figure 61). In household wastewater and biodegradable solid waste, the main proportion of the plant nutrients are found in the toilet water (i.e., in urine and feces). In order to recover most of these nutrients, with the purpose of decreasing the emission of eutrophication agents and of increasing their recycling, present waste and wastewater systems have to be changed.

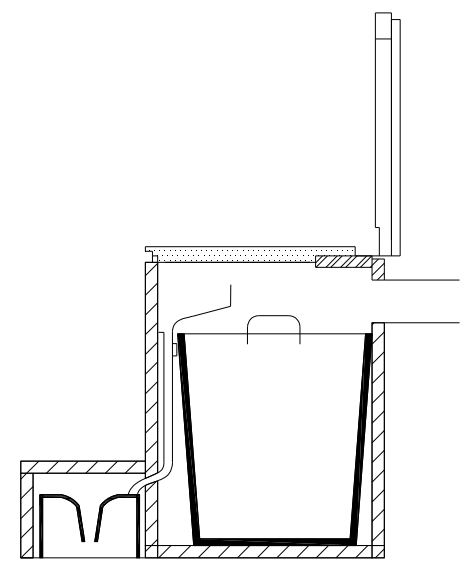

Figure 60. Marino's urine-separating toilet (sketch by A. Angelakis inspired from [130]). 

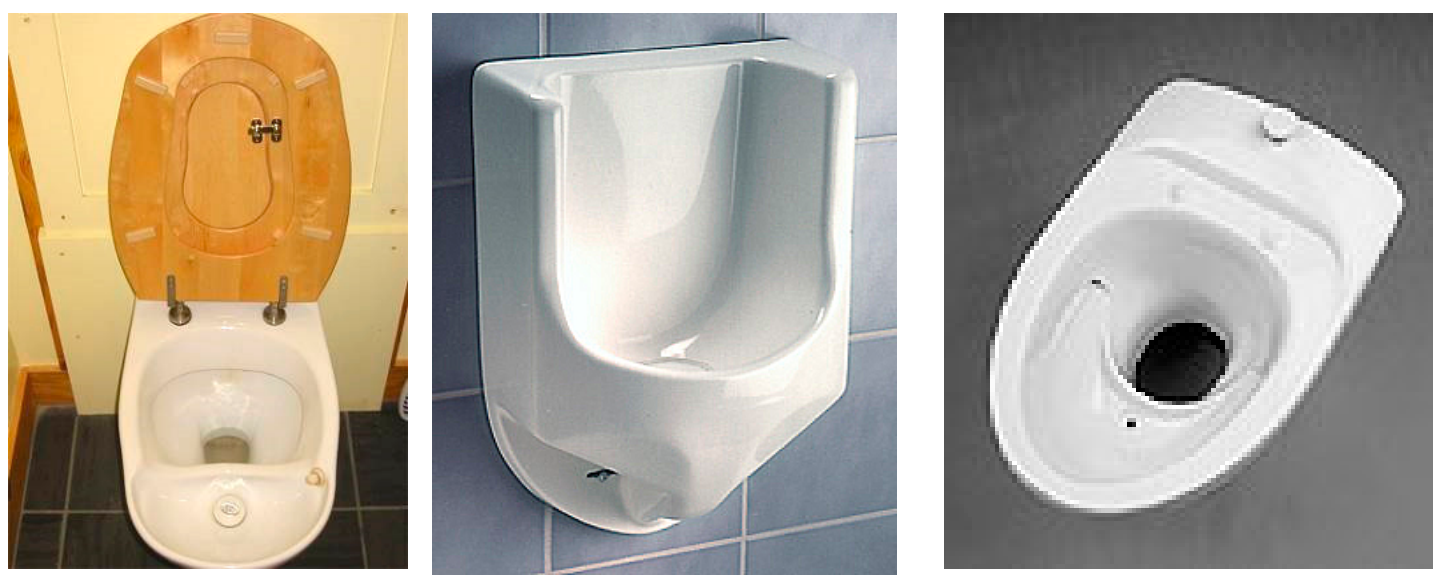

Figure 61. Three different types of urine-separation fixtures (with permission of G. Tchobanoglous).

Urine-separating toilets have been used as an effective means of separating the urine from feces in many parts of Europe and elsewhere in the world for years. The purpose of UST is to separate nutrients $(\mathrm{N}, \mathrm{P}$, and $\mathrm{K}$ ) at the source [132]. Although up to about $80 \%$ of $\mathrm{N}, 50 \%$ of $\mathrm{P}$ and $60 \%$ of $\mathrm{K}$ are contained in urine, its volumetric fraction of total wastewater flow is only around 1\% (Figure 62). By first separating the urine, many nutrients can be captured and reused without intensive, expensive and time-consuming treatment required when urine is combined with feces [133]. Urine can be reused as a concentrated fertilizer with only limited treatment prior to land application. However, if the urine and the feces are collected, up to $91 \%, 83 \%$ and $59 \%$ for N, P and K, respectively, can be recovered and recycled from the household wastewater [129].

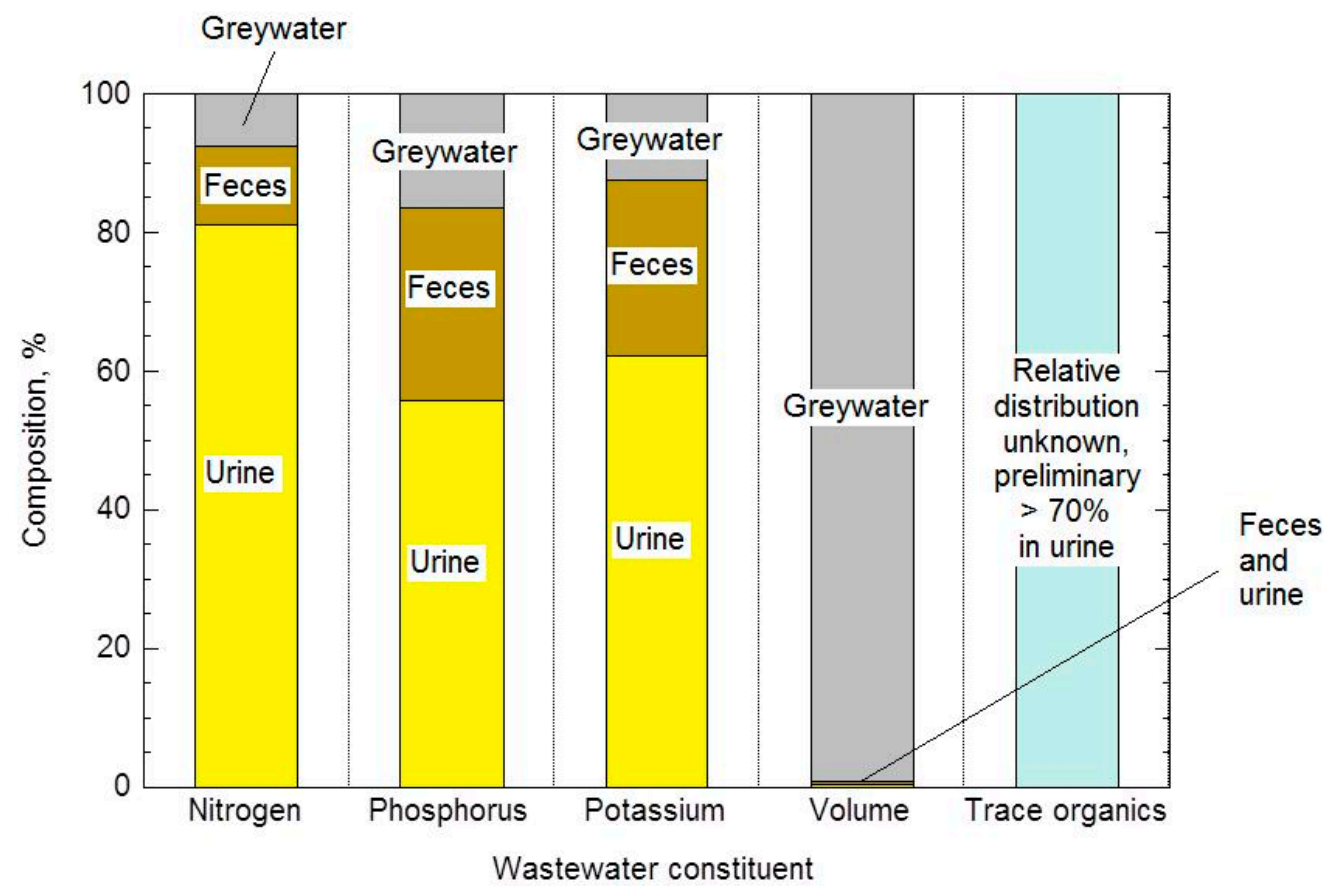

Figure 62. The percentage of nutrients in various wastewater components (with permission of G. Tchobanoglous).

Urine separation technology is well accepted in European countries; where around $80 \%$ of users liked the idea, $75 \%-85 \%$ were satisfied with design, hygiene, smell, and seating comfort of urine separation-toilets, $85 \%$ regarded urine-fertilizers as a good idea ( $50 \%$ offarmers), and $70 \%$ would purchase 
such food. However, $60 \%$ of users encountered problems [134] indicating that urine separation-toilets need further development. Except for "evaporation" and "storage", none of the processes described have so far advanced beyond the laboratory stage. Considerable development work remains to be done to optimize urine-processing techniques in order to create marketable products.

(c) Spacecraft toilets. Space toilets used in zero-gravity spacecraft are usually urine-diverting dry toilets, a form of dry toilet. A vacuum-cleaner-like machine is used to suck up the wastes. The excreta are then vacuum-dried and the urine is used to recover water.

\subsection{Inspiring Aspects!}

Beside the technical and engineering trends, another worth mentioning aspect regarding the toilet vessel nowadays is the related various artistic and other inspiration, since it is an integral item of the everyday life of the developed world. The shape and sometimes the item itself has become shape of a building (Figure 63a) or even a bomb (Figure 63b).

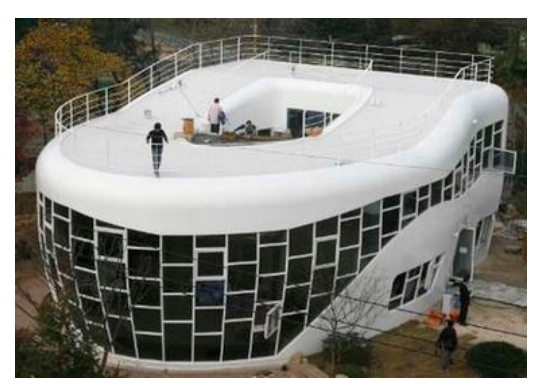

(a)

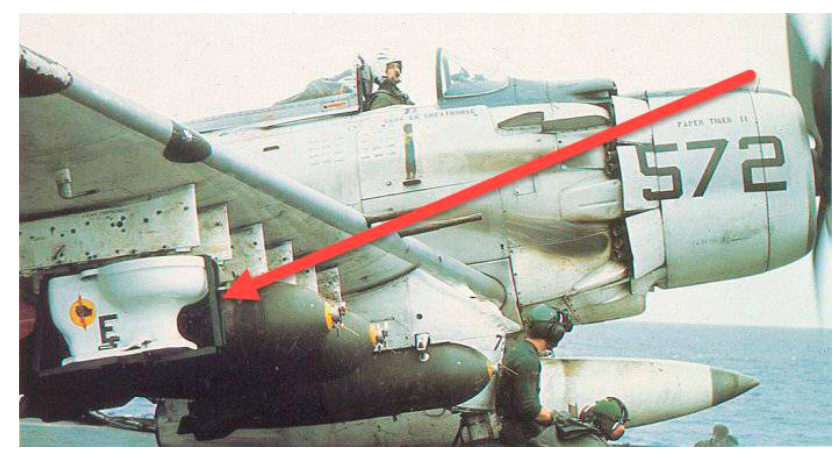

(b)

Figure 63. (a) Toilet house in Japan (Wikiality) and (b) Toilet bomb on an A-1H Skyrider from USS 41 Midway, October 1965, in commemoration of the 6-millionth pound of ordnance dropped over Vietnam (Wikipedia).

\section{Discussion and Conclusions}

The first toilets and waste management systems functioned by direct disposal (cesspits) and/or by transporting to distant places using pipes that first appeared in ancient Mesopotamia about 6000 years ago. In the 2nd millennium BC, Minoans in Crete, Greece and at the same time in the Indus valley were developing baths and toilets with hand-flashing technology. Early in the 1st millennium BC Egyptians used cesspool lavatories which were located indoors in wealthy houses and outdoors for other dwellings. At the same time the Mycenaeans in Greece were developing similar technologies. Later on, the Greeks in early 4th c. BC established a system incorporating a flushing flow underneath a multi-seat stone or wooden bench. In China, the earliest records concerning the construction of toilet were made during the Warring States period (475-221 BC). By the end of the 1st millennium BC, other civilizations worldwide were using some kind of toilets and other sanitary facilities. The Roman technology improved their systems in many ways and incorporated ergonomic features. Overall ancient knowledge survived for a certain period in the post antiquity era. However, during the Middle Ages it diminished; however, some monastic lavatory examples, such as the necessaria, were retained. In the medieval Islamic world, i.e., in the medieval towns of the Iberian Peninsula, hydraulic hygiene facilities were remarkable as a latrine connected to a sewer or cesspits was widely used and was found in almost every house. The importance of defecation hygiene etiquette related to religion, should not be excluded as an aspect to the evolution of the toilet. The various simple efforts to control odor during earlier periods ended with the S-trap pipes during the early industrial era. Because of the utilitarian character of the toilet most of the pre-industrial examples were lost. 
Although a great deal of research and literature with an emphasis on the historical development of hydraulic infrastructure in ancient civilizations are known, there is still a lack of corresponding information on toilets and other relevant sanitary facilities. This is somewhat surprising since the lack of sanitation affects human development to the same or an even greater extent as the lack of clean water. Hence, this paper has focused on tracing the development of toilet technologies of the ancient civilizations and to examine their influence through the centuries to more recent times and beyond.

Even though the lack of proper toilet facilities for a great percentage of the global population is even nowadays an embarrassing fact, the worldwide efforts through the millennia for the acquisition of a well-engineered toilet were connected to the cultural level of each period. Unfortunately, most of the remains of the toilets-lavatories of the past were not very well preserved and studied because of the nature of their function and our "natural" aversion to human waste. On the other hand, the remains of toilets at archaeological sites and monuments very often attract more visitors. The limited written sources referring to relevant matters had a totally different main subject, and the incorporation of lavatory information is often related with sarcastic comments as in Aristophanes comedies or directives as in Byzantine monastic Typika. Undoubtedly, the lack of sanitation and the consequential bacterial infections have killed more victims than armed conflicts throughout human history. Therefore, most cultures tried to attain a functioning and hygienic lavatory, as can be traced by the examples presented herein.

In addition, the study of the various sanitary infrastructures throughout history at various geographical locations (Appendix), shows that the issues of wastewater management, flushing, comfort of the users, odor control, etc., were more or less successful. Moreover, studying the history of lavatories offers the possibility to study the history of mankind from a very unique perspective: it is as if someone rummages in the garbage bin trying to understand the habits of a family. Besides that, it can also be concluded that the lavatory and sanitary infrastructure is quite often related to the wealth and prosperity of a society. For example, the royal sitting lavatory with a flush at Knossos in Minoan Crete significantly differs from the simple residential toilet in Malia. In general, during most eras the well formed examples were found regularly in wealthy rather than in ordinary houses. The presence of financial prosperity and cultural growth contributed to these improvements and, on the contrary, improvements in lavatories and wastewater management tremendously influenced human development. From a technical point of view, it can be documented and therefore concluded fairly well that in many cases the engineering and practical requirements, such as the water flow for flushing, prevailed over cultural principles, such as the strict privacy for the defecation. It is also evident through the study of several examples that most of the relevant technical achievements survived, somehow, through the centuries and the political, cultural, and religious reformations. It is also concluded that even though the continuation of the relevant technical practices was diminished through the various barbaric raids and invasions, it seems that usually they reappeared later on, often improved. Recently, C. Wald who discussed the issue of ancient toilets [135] stated: there's going to be a lot of value in it, as opposed to being, like, oh, it's just a toilet.

Along with any conclusions it should be mentioned that, despite the journey for sanitation and the toilet in the developed world having been accomplished, it continues in the developing parts of the world [27]. U.N. Deputy Secretary-General, Jan Eliasson stated in May 2014: "I am moved by the fact that a child dies every 2 and a half minutes from diseases linked to open defecation. Those are silent deaths-not reported on in the media, not the subject of public debate. Let's not remain silent any longer..."

Author Contributions: Each of the author's contributions mostly depended upon their region of origin. A. Angelakis contributed mainly to Minoan Era, 20th c., Future Trends, Introduction and Summary. G. Antoniou mainly contributed to the Classical and Hellenistic periods, medieval times, Japanese examples, pre Industrial era and partially in the pre-Colombian toilets. G. De Feo and E. Kanetaki contributed mainly to the Roman and Ottoman periods respectively. I. Reklaityte contributed to Iberian Medieval times. Xiao Yun Zheng and Fang Tie contributed to Chinese civilizations. F. Fardin and S. Khan contributed mainly to Indian valley civilizations. A. Tamburrino contributed to Pre-Columbian America and wrote the Ancient Mesopotamian section. Larry Mays, besides his contribution on the Introduction and the Conclusions, he edited and proofread the entire text.

Conflicts of Interest: The authors declare no conflict of interest. 


\section{Appendix. Timeline of Toilets}

\begin{tabular}{|c|c|}
\hline $3000 \mathrm{BC}$ & Cesspits for disposal of wastewater in Mesopotamian cities. \\
\hline $2500 \mathrm{BC}$ & Toilets in baths of Mesopotamian cities. \\
\hline $2000 \mathrm{BC}$ & Squat type toilets in Minoan settlements. \\
\hline $1900 \mathrm{BC}$ & $\begin{array}{l}\text { Indus valley civilization streets were built on a grid pattern and networks of } \\
\text { sewers were dug under them. Toilets were flushed with water. }\end{array}$ \\
\hline $1700 \mathrm{BC}$ & Flushed toilets in the palace of Knossos on Crete, Greece. \\
\hline $1200 \mathrm{BC}$ & $\begin{array}{l}\text { Ancient rich Egyptians had proper bathrooms and toilets in their homes (Toilet } \\
\text { seats were made of limestone). }\end{array}$ \\
\hline $350 \mathrm{BC}$ & $\begin{array}{l}\text { The typical ancient Greek multi seat domestic or public lavatory is being formed } \\
\text { incorporating underneath a sewer duct with temporary or continuous flow. }\end{array}$ \\
\hline $206 \mathrm{BC}-24 \mathrm{AD}$ & A toilet in the tomb of a Chinese King (Western Han Dynasty). \\
\hline $100 \mathrm{AD}$ & $\begin{array}{l}\text { Romans build well organized and large scale public lavatories usually supplied } \\
\text { with continuous water flow provided by their aqueducts. }\end{array}$ \\
\hline 200-300 AD & The Romans apply a kind of predecessor of the medieval Garderobe. \\
\hline 500-1000 AD & $\begin{array}{l}\text { Multi seat lavatories are still been built in monastic complexes in both } \\
\text { Mediterranean area and western Europe. Squat toilets and cesspits are widely } \\
\text { used in the Iberian Peninsula }\end{array}$ \\
\hline 750-1000 AD & $\begin{array}{l}\text { In Shibam, Yemen toilets had two outlets: a front outlet for urine and a back } \\
\text { outlet for feces are referred [64]. }\end{array}$ \\
\hline 800 & $\begin{array}{l}\text { The Garderobe becomes a typical-usually hanging out-toilet for Medieval Europe. } \\
\text { Excrements were falling in the river or moat below or at the open ground. } \\
\text { The sitting position was established as a manner of comfort. }\end{array}$ \\
\hline Middle ages & $\begin{array}{l}\text { In Medieval Europe a special metal or ceramic bowl the chamber pot was } \\
\text { commonly and widely used. Its contents were tossed out (often out the window). }\end{array}$ \\
\hline 1500 & $\begin{array}{l}\text { Ordinary people often use the leaves of a plant called woolly mullein as } \\
\text { toilet paper. }\end{array}$ \\
\hline 1556 & $\begin{array}{l}\text { Sir John Harrington invented a flushing lavatory with a cistern (built for } \\
\text { Queen Elizabeth). }\end{array}$ \\
\hline 1775 & Alexander Cumming was granted a patent for a flushing lavatory. \\
\hline 1857 & $\begin{array}{l}\text { The first packaged toilet paper was invented by the American, Joseph Gayetty } \\
\text { and called Gayetty's Medicated Paper. }\end{array}$ \\
\hline 1879 & $\begin{array}{l}\text { The Scott Paper Company began selling the first toilet paper on a roll; however, } \\
\text { toilet paper in roll form did not become common until } 1907 \text {. }\end{array}$ \\
\hline 1880 's & $\begin{array}{l}\text { England's Prince Edward (later to become King Edward VII) hired a prominent } \\
\text { London plumber named Thomas Crapper to construct lavatories in several } \\
\text { royal palaces. }\end{array}$ \\
\hline 1890 & $\begin{array}{l}\text { Flushable valves, water tanks that rest on top of the bowl rather than above, and } \\
\text { toilet-paper rolls invented. }\end{array}$ \\
\hline 1910 & $\begin{array}{l}\text { Beginning in 1910, toilet designs started changing away from the elevated water } \\
\text { tank into the modern toilet with a close tank and bowl. }\end{array}$ \\
\hline
\end{tabular}

\section{References}

1. De Feo, G.; Antoniou, G.P.; Mays, L.; Dragoni, W.; Fardin, H.F.; El-Gohary, F.; Laureano, P.; Kanetaki, E.I.; Zheng, X.Y.; Angelakis, A.N. Historical development of waste water management. In Handbook of Engineering Hydrology; Eslamian, S., Ed.; Taylor \& Francis Group: Boca Raton, FL, USA, 2014; Charpter 9; Volume 2, pp. 163-217.

2. Pruthi, R.K. Prehistory and Harappan Civilization; APH: Delhi, India, 2004. 
3. Kenoyer, J.M. Ancient Cities of the Indus Valley Civilization; University of Wisconsin: Madison, WI, USA, 1998. Available online: http://sites.fas.harvard.edu/ fc12/Bibliography/01_Indus_Bibliography.html (accessed on 20 June 2016).

4. Kenoyer, J.M. Mohenjo-Daro. In An Ancient Indus Valley Metropolis; University of Wisconsin: Madison, WI, USA, 1998. Available online: https:/ / www.harappa.com/essays (accessed on 20 December 2015).

5. James, P.; Thorpe, N. Ancient Inventions; Ballantine Books: New York, NY, USA, 1995.

6. Harter, S.; Bouchet, F.; Zias, J.; Mumeuoglou, K.Y. Toilet practices among members of the Dead Sea Scroll sect at Qumran. Rev. Qumran 2004, 21, 579-584.

7. Zias, J.; Tabor, J.D.; Harter-Lailheugue, S. Toilets at Qumran, the Essenes, and the scrolls, new anthropological data and old theories. Rev. Qumran 2006, 22, 631-640.

8. Cahill, J.; Reinhard, K.; Tarler, D.; Warnock, P. It had to happen: scientists examine remains of ancient bathroom. Biblic. Archaeol. Rev. 1991, 17, 64-69.

9. Antoniou, G.P. Lavatories in Ancient Greece. In Water Science and Technology, Water Supply; IWA: London, UK, 2007; Volume 7, pp. 155-164.

10. Angelakis, A.N.; Spyridakis, S.V. The status of water resources in Minoan times: A preliminary study. In Diachronic Climatic Impacts on Water Resources with Emphasis on Mediterranean Region; Angelakis, A.N., Issar, A.S., Eds.; Springer-Verlag: Heidelberg, Germany, 1996; Chapter 8, pp. 161-191.

11. Pritchard, J.B. (Ed.) Ancient Near Eastern Texts Relating to the Old Testament, 3rd ed.; Princeton University Press: Princeton, NJ, USA, 1969.

12. Alizadeh, A. Chogha Mish. The Development of a Prehistoric Regional Center in Lowland Susiana, Southwestern Iran: Final Report on the Last Six Seasons of Excavations, 1972-1978; Oriental Institute Publications, OIP 130; The Oriental Institute of the University of Chicago: Chicago, IL, USA, 2008; Volume 2.

13. Delougaz, P.; Hill, H.D.; Lloyd, S. Private Houses and Graves in the Diyala Region; Oriental Institute Publications, The University of Chicago Press: Chicago, IL, USA, 1967; Volume LXXXVIII.

14. Ludwig, W. Mass, sitte und Technick des Bauens in Habuba Kabira Sud. In Le Moyen Euphrate, Zone de Contacts et d' Echanges; Margueron, J.C., Ed.; Actes du Colloque de Strasburg: Strasburg, France, 1977; pp. 63-74. (In German)

15. Vallet, R. Habuba Kebira ou la naissance de l'urbanisme. Paleorient 1997, 22, 45-76. (In French) [CrossRef]

16. Margueron, J.-C. Cités Invisibles; Libraire Orientaliste Paul Geuthner S.A.: Paris, France, 2013. (In French)

17. Yon, M. The City of Ugarit at Tell Ras Shamra; Eisenbrauns: Winona Lake, IN, USA, 2006.

18. Margueron, J.-C. Notes d'archéologie et d'architecture orientales 15. In Installations Hygiéniques ou Artisanales? Syria: Archeologie, Art, et Histoire; Institut Français du Proche-Orient: Paris, France, 2008; Volume 85, pp. 175-221. (In French)

19. Baker, H.D. Urban form in the first millennium BC. In The Babylonian World; Leick, G., Ed.; Routledge: New York, NY, USA, 2007.

20. Banks, E.J. Bismya or the Lost City of Adab; The Knickerbocker Press: New York, NY, USA, 1912.

21. McMahon, A. Waste management in early urban southern Mesopotamia. In Sanitation, Latrines and Intestinal Parasites in Past Populations; Mitchell, P., Ed.; Ashgate Publishing Ltd.: Farnham, UK, 2015; pp. 19-35.

22. Angelakis, A.N.; Koutsoyiannis, D.; Tchobanoglous, G. Urban Wastewater and Stormwater Technologies in the Ancient Greece. Water Res. 2005, 39, 210-220. [CrossRef] [PubMed]

23. De Feo, G.; Antoniou, G.; Fardin, H.F.; El-Gohary, F.; Zheng, X.Y.; Reklaityte, I.; Butler, D.; Yannopoulos, S.; Angelakis, A.N. History of Sanitary Sewers Worldwide. Sustainability 2014, 6, 3936-3974. [CrossRef]

24. Antoniou, G.P.; Angelakis, A.N. Wastewater and stormwater sanitation technologies in ancient Greece. In Sanitation, Latrines and Intestinal Parasite in Past Populations; Mitchell, P., Ed.; Ashgate: Farnham, UK, 2015; pp. 41-68.

25. Castleden, R. Minoans: Life in Bronze Age Crete; Routledge: London, UK, 1993.

26. Angelakis, A.N.; Kavoulaki, E.; Dialynas, M.G. Sanitation and Stormwater and Wastewater Technologies in Minoan Era. In Evolution of Sanitation and Wastewater Management through the Centuries; Angelakis, A., Rose, J., Eds.; IWA Publishing: London, UK, 2014; pp. 1-24.

27. Pathak, B. The history of toilets. In Proceedings of the International Symposium on Public Toilets, Hong Kong, China, 25-27 May 1995.

28. UNC. College of Arts and Sciences, 2013. Available online: http://classics.unc.edu/academics/courses-2/clar244/image-directory/late-bronze-age-images/knossos-palace-of-minos-images/ (accessed on 29 June 2016). 
29. Graham, J.W. The Palaces of Crete; Princeton University Press: Princeton, NJ, USA, 1987.

30. Angelakis, A.N.; Spyridakis, S.V. Wastewater Management in Minoan Times. In Proceedings of the Meeting on Protection and Restoration of Environment, Chania, Greece, 28-30 August 1996; pp. 549-558.

31. Palyvou, C. Akrotiri Thera: An Architecture of Affluence 3500 Years Old; INSTAP: Philadelphia, PA, USA, 2005; pp. 41-42, 51-53.

32. Hogan, C.M. Knossos Fieldnotes. The Modern Antiquarian, 2007. Available online: http://www. themodernantiquarian.com/site/10854/knossos.html\#fieldnotes (accessed on 25 June 2016).

33. Sharma, L.P. Ancient India History, Indus Valley Civilization. 1992. Available online: http://www. culturalindia.net/indian-history/ancient-india/indus-valley.html (accessed on 25 June 2016).

34. Saleem, S. Harappa and Mohenjo Daro. 2012. Available online: http://ugghani.blogspot.in/2012/06/ harappa.html (accessed on 25 June 2016).

35. Wright, R.P. The Ancient Indus: Urbanism, Economy, and Society; Cambridge University Press: New York, NY, USA, 2010.

36. Hooper, A. What Is the Complete History of the Toilet? 2011. Available online: http://answers.yahoo.com/ question/index?qid=20120220121010AARe9nX (accessed on 25 June 2016).

37. French, K.D.; Duffy, C.J. Prehispanic water pressure: A New World first. J. Archaeol. Sci. 2010, 37, 1027-1032. [CrossRef]

38. French, K.D. (Department of Anthropology, The Pennsylvania State University, University Park, PA 16802, USA). Personal communication, 28 January 2014.

39. Mozi (墨子). Mozi; Zhonghua Book Bureau: Beijng, China, 1996; p. 109.

40. Xuzhou Museum. A bulletin to clear up Lizhuang western Han grave at Tongshan country Jiangsu province. J. Archaeol. 1995, 3, 12-15.

41. Yang, X.G.; Ban, G. Wy Wyzi Part. In Book of Han; Zhongua Book Bureau: Beijing, China, 1912; Volume 63.

42. Kurosaki, S. The Toilet Features of the Fujiwara Palace Site; Nabunken: Nara, Japan, 1992.

43. Matsui, A.; Kanehara, M.; Kanehara, M. Palaeoparasitology in Japan-Discovery of toilet features. In Memórias do Instituto Oswaldo Cruz; Instituto Oswaldo Cruz: Rio de Janeiro, Brazil, 2003.

44. Antoniou, G.P. Ancient Greek lavatories: Operation with reused water. In Ancient Water Technologies; Mays, L.W., Ed.; Springer: New York, NY, USA, 2010; pp. 67-87.

45. Antoniou, G.P.; Lyberatos, G.; Kanetaki, E.I.; Kaiafa, A.; Voudouris, K.; Angelakis, A.N. History of urban wastewater and stormwater sanitation technologies in Greece. In Evolution and Sanitation Technologies through the Centuries; Angelakis, A., Rose, J., Eds.; IWA: London, UK, 2014; Chapter 6, pp. 101-148.

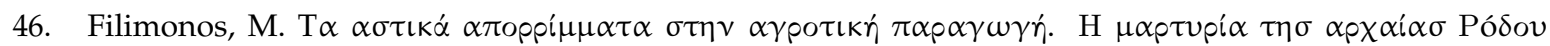
(Urban waste in agricultural production. The testimonies of ancient Rhodes). In Proceedings of the

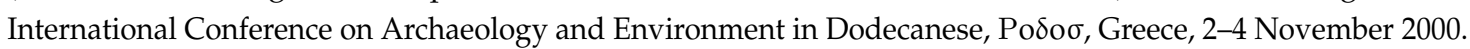
(In Greek).

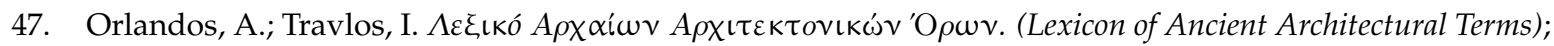
A. E.: Athens, Greece, 1986. (In Greek)

48. Robinson, D. Olynthos VIII; Johns Hopkins Press: Baltimore, MD, USA, 1938.

49. Delorme, J. Gymnasion; De Boccard: Paris, France, 1960. (In French)

50. Hoepfner, W. (Ed.) Geschichte des Wohnens; Deutsche Verlags-Anstalt: Stuttgart, Germany, 1999. (In German)

51. Trumper, M. Hellenistic Latrines (3rd-1st century BC). In Roman Toilets. Their Archaeology and Cultural History; Jansen, G., Koloski-Ostrow, A., Moormann, E., Eds.; Babesch: Leuven, Belgium, 2011; pp. 33-42.

52. Chamonard, J. Le Quartier du Theatre; Collection Exploration archeologique de Delos. De Boccard: Paris, France, 1924.

53. Hansen, R.D. Water and Wastewater in Imperial Rome. Water Resour. Bull. 1983, 19, 263-269. [CrossRef]

54. Orlandos, A. The Role of the Roman Building Located Northern of Horologe of Andronikos Kiristos; Athens Academy: Athens, Greece, 1940. (In Greek)

55. Myriantheos, M. The Bastion at the SE side of the Sinai monastery wall. In Proceedings of the 7th Symposium of Byzantine Archaeology and Art, Athens, Greece, 24-26 April 1987. (In Greek).

56. Boussac, M.F.; Fournet, T.; Redon, B. Le Bain Collectif en Egypte; IFAO: Caire, Egypt, 2009.

57. Vuorinen, H.S. Water, toilets and public health in the roman era. Water Sci. Technol. Water Suppl. 2010, 10, 411-415. [CrossRef] 
58. De Feo, G.; Laureano, P.; Drusiani, R.; Angelakis, A.N. Water and wastewater management technologies through the centuries. Water Sci. Technol. Water Suppl. 2010, 10, 337-349. [CrossRef]

59. Hobson, B. Latrinae et Foricae: Toilets in the Roman World, 1st ed.; Duckworth: London, UK, 2009.

60. Jansen, G.C.M.; Koloski-Ostrow, A.O.; Moormann, E.M. (Eds.) Roman Toilets, 1st ed.; Peeters Publishers: Leuven, Belgium, 2011.

61. De Feo, G.; De Gisi, S.; Hunter, M. Sanitation and wastewater technologies in ancient Roman cities. In Evolution of Sanitation and Wastewater Technologies through the Centuries; Angelakis, A.N., Wilderer, P.A., Rose, J.B., Eds.; IWA Publishing: London, UK, 2014.

62. Kolowski-Ostrow, A.O. Finding Social Meaning in the Public Latrines of Pompeii. In Cura Aquarum in Campania, Proceedings of the Ninth International Congress on the History of Water Management and Hydraulic Engineering in the Mediterranean region, Pompeii, Italy, 1-8 October 1994; Haan, N., de Jansen, G.C.M., Eds.; Stichting Babesch: Leiden, Belgium, 1996; pp. 79-86.

63. De Feo, G.; Napoli, R.M.A. Historical development of the Augustan aqueduct in Southern Italy: Twenty centuries of works from Serino to Naples. Water Sci. Technol. Water Suppl. 2007, 7, 131-138. [CrossRef]

64. Jansen, G. Systems for the Disposal of Waste and Excreta in Roman Cities. The Situation in Pompeii, Herculaneum and Ostia. In Sordes Urbis: La Elimanación de Residuos en la Ciudad Romana. Actes de La Reunión de Roma (15-16 Novembe 1996); Raventós, X.D., Remolà, J-A., Eds.; L’Erma di Bretschneider: Roma, Italy, 2000; pp. 37-49.

65. Keenan, D. Water supply and wastewater disposal in Pompeii: An overview. Anc. Hist. Resour. Teach. 2005, 34, 149-158.

66. NOFSR (Netherlands Organization for Scientific Research). The Romans Preferred Small-Scale Solutions to Aqueducts and Sewers. Science Daily, 1970. Available online: http://www.sciencedaily.com-/releases / 2002/06/020627010620.html (accessed on 5 May 2013).

67. Jansen, G.C.M. Toilets and Health. In Roman Toilets, 1st ed.; Jansen, G.C.M., Koloski-Ostrow, A.O., Moormann, M., Eds.; Peeters Publishers: Leuven, Belgium, 2011; pp. 157-164.

68. Szymanska, H.; Babraj, K. Le Bains de Marea. In Le Bain Collectif en Egypte; Boussac, M.-F., Fournet, T., Redon, B., Eds.; IFAO: Caire, Egypt, 2009. (In French)

69. Muller-Wiener, W. Castles of the Crusades; Thames \& Hudson: London, UK, 1966.

70. Yannopoulos, S.; Yapijakis, C.; Kaiafa-Saropoulou, A.; Antoniou, G.; Angelakis, A. History of Sanitation and Hygiene Technologies in the Hellenic World. J. Water Sanit. Hyg. Dev. 2016, in press.

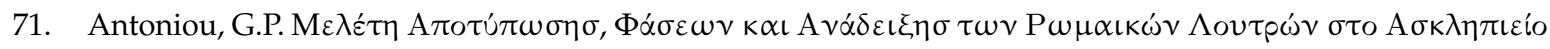
$\mathrm{E} \pi \iota \delta \alpha u ́ p o v$ (Study for the Recording and Enhancement of the Roman Bath at the Asklepieion of Epidaurus). Unpublished work, 1998. (In Greek).

72. Orlandos, A. Mov $\alpha \sigma \tau \eta \rho \iota \alpha \kappa \dot{~ A \rho \chi \imath \tau \varepsilon \kappa \tau o v \iota к n ́ ~(M o n a s t e r i e s ' ~ A r c h i t e c t u r e), ~ 1 s t ~ e d . ; ~ E \sigma \tau i ́ ~} \alpha$ : Athens, Greece, 1927. (In Greek)

73. Yavuz, A. The Baths of Anatolian Seljuk Caravansarais. In Acts of Conference Bathing Culture of Anatolian Civilizations; Ancient Near Eastern Studies, Supplement 37; Ergin, N., Ed.; Peeters: Leuven, Belgium, 2011; pp. 77-141.

74. Papanggelos, I. Athonian Monastery of Zygos; Papaioannou, K.S.: Thessaloniki, Greece, 2005. (In Greek)

75. Gaubert, M. Bains et les Moines. In Le Bain Collectif en Egypte; Boussac, M., Fournet, T., Redon, B., Eds.; IFAO: Caire, Egypt, 2009; pp. 297-303.

76. Henein, N.H.; Kellia, M.W. L'ermitage Copte QR 195. I. Arch ologie et Architecture. Plans. Fouilles de l'IFAO 41; Institut Frannais d'Archıologie Orientale: Caire, Egypt, 2000. (In French)

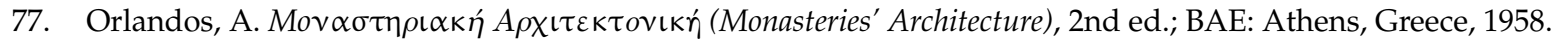
(In Greek)

78. Monneret de Villard, U. Annales du Service de Antiques de l'Egypte; CSA: Paris, France, 1926. (In French)

79. Panoramio, Sinai Monastery by Krystian Haraburda. Available online: http://www.panoramio.com/photo/ 73592289 (accessed on 12 December 2015).

80. Kwidzyn Castle by K. Knapczyk. Available online: http://www.panoramio.com/photo/108059396 (accessed on 12 December 2015).

81. Bodiam Castle by Vl. Tzekov. Available online: http://www.panoramio.com/photo/47430620 (accessed on 12 December 2015). 
82. Portchester Castle Lavatories. Available online: https://i1.wp.com/farm4.static.flickr.com/3615/ 4552339814_6659c4e1f6_m.jpg (accessed on 12 December 2015).

83. Chillon Casle by Eldar Kadymov. Available online: http://www.pbase.com/eldarrio/image/76277802 (accessed on 12 December 2015).

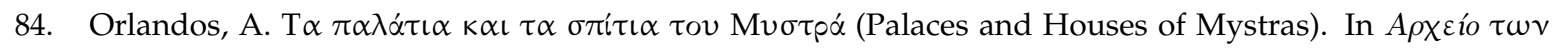

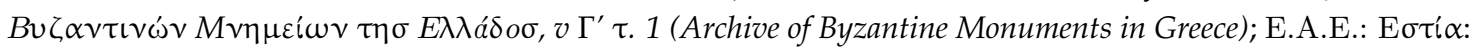
Athens, Greece, 1937. (In Greek)

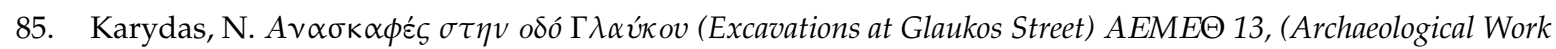
in Macedonia and Thrace); YPPO: Thessaloniki, Greece, 1999; pp. 370-374. (In Greek)

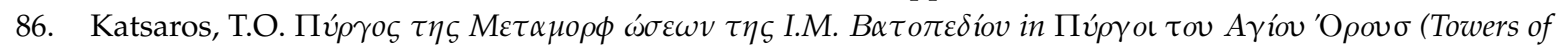
Mt Athos); Armos: Thessaloniki, Greece, 2000; pp. 45-49. (In Greek)

87. Velenis, G. Wohnviertel und Wohnungsbau in den Byzantinischen Stadten, Wohnungsbau im Altertum, Discussionen zur Archeologischen Bauforschung 3; Horsaal: Berlin, Germany, 1978; pp. 227-236.

88. Wright, L. Clean and Decent; Penguin Group: London, UK, 2003.

89. Theoharidis, P. Examples of residence in Mt Athos Forts, Castles and Monasteries cells of the early Ottoman period. The monastery of Simonos Petra. In Greek Traditional Architecture: Macedonia B; Lavas, G., Philipedes, D., Eds.; Melissa, Athens, 1991; Volume 8, pp. 271-276.

90. Kaufmann, E.; Kaufmann, H.W. The Medieval Fortress: Castles, Forts, and Walled Cities of the Middle Ages; De Capo: Cambridge, MA, USA, 2004; pp. 49-51.

91. Green, J.P. Medieval Monasteries, Archaeology of medieval Britain; Leicester University: Leicester, UK, 1992.

92. Templar Wisdom. Available online: https://templarwisdom.worldpress.com/acre (accessed on 5 December 2015).

93. Hodgson, J. A History of Northumberland; E. Walker: Newcastle, UK, 1840; pp. 367-368.

94. Eveleigh, D.J. Bogs, Baths and Basins. The Store of Domestic Sanitation; Stroud: Sutton, UK, 2002.

95. Hensel, W. Słowiańszczyzna Wczesnośredniowieczna; Panstowowe Wydawnictwo Naukowe: Warszawa, Poland, 1987.

96. Leguay, J.P. La rue au Moyen Âge; Université de Rennes: Rennes, France, 2002.

97. Guerrand, R.H. Las letrinas. Historia de la Higiene Urbana; Ediciones Alfons El Magnanim: Valencia, Spain, 1991. (In Spanish)

98. Frugoni, C. Vivir en la ciudad. Mundo Med. 2003, 13, 14-15. (In Spanish)

99. Keene, D.J. Rubbish in medieval towns. In Environmental Archaeology in the Urban Context; Research Report 43; Council for British Archaeology: York, UK, 1982; pp. 26-30.

100. Colinsnotes. Available online: http://www.colinsnotes.com/wp-content/uploads/2012/12/027-04.jpg (accessed on 14 March 2015).

101. Italyheaven. Available online: http://www.italyheaven.co.uk/campania/ischia/ischiaponte.html (accessed on 14 March 2015).

102. Córdoba de la Llave, R. Eliminación y reciclaje de residuos urbanos en la Castilla bajomedieval. Acta Hist. Archaeol. Med. 1998, 19, 143-169. (In Spanish)

103. Reklaityte, I. Vivir en una Ciudad de al-Ándalus: Hidráulica, Saneamiento y Condiciones de Vida; Universidad de Zaragoza: Zaragoza, Spain, 2012. (In Spanish)

104. Navarro Palazón, J.; Jiménez Castillo, P. Siyāsa. Estudio Arqueológico del Despoblado Andalusí (s. XI-XIII); Fundación Caja Murcia: Murcia, Spain, 2005. (In Spanish)

105. Vallejo Triano, A. La Ciudad Califal de Madinat al-Zahra: Arqueología de su Excavación; Almuzara: Cordoba, Spain, 2010. (In Spanish)

106. Navarro Palazón, J.; Jiménez Castillo, P. El agua en la vivienda andalusí: Abastecimiento, almacenamiento y evacuación. Verdolay 1995, 7, 401-412. (In Spanish)

107. Pizarro Berengena, G. El alcantarillado árabe de Córdoba II. Evidencia arqueológica del testimonio historiográfico. Anejos An. Arqueol. Cordob. 2009, 2, 231-246. (In Spanish)

108. Kanetaki, E. Bathhouses in the Former Ottoman Province of the Greek Lands: A Contribution to the Study of their History and Architecture. In Acts of Conference Bathing Culture; 2007 Istanbul, Ancient Near Eastern Supplement Series 37; Ergin, N., Ed.; Peeters: Leuven, UK, 2011; pp. 221-255.

109. Bearman, P.J.; Blanquis, T.; Bosworth, C.E.; van Donzel, E.; Heinrichs, W.P. (Eds.) Wudu. In The Encyclopædia of Islam, 2nd ed.; Brill: Leiden, The Netherland, 2001; pp. 218-219.

110. Goodwin, G. A History of Ottoman Architecture; Thames and Hudson Ltd.: London, UK, 1971; (Reprinted in 2003). 
111. Kanetaki, E. The Creation of Historical Cultural Heritage in Greece during the Ottoman Period. In Acts of the International Symposium on Historical Ottoman Artifacts and Foundations (Awqaf) in the Balkans; T.C.B.V.G.M, Cult. Te. Dir.Bask.: Ancara, Turkey, 2012; pp. 197-208.

112. Önge, Y. Toilets in Turkish Ottoman architecture. In Acts of the Seventh International Congress of Turkish Art; Majda, T., Ed.; Polish Scientific Publishers: Warsaw, Poland, 1990; pp. 185-190.

113. Ayverdi, E.H. Osmanlı Mîmârîsi'nin İlk Devr; İSTANBUL FETİH CEMIYYETİ YAYINLARI: Istanbul, Turkey, 1966. (In Turkish)

114. Neçipoğlu, G. The Age of Sinan: Architectural Culture in the Ottoman Empire; Reaktion Books: London, UK, 2005.

115. Ünver, S. İstanbul Yedinci Tepe Hamamlarına Dair Bazı Notlar. Vakıflar Dergisi. 1942, 2, 245-251. (In Turkish)

116. Kanetaki, E. Othomanika Loutra ston Elladiko Xwro (Ottoman Baths in the Greek Territory); Technical Chamber of Greece: Athens, Greece, 2004. (In Greek)

117. Günay, R. Safranbolu Houses; Yapi Yayin: Istanbul, Turkey, 2003.

118. Lui, Y.Q. The New Words of the Day (世说新语); Zhonghua Book Bureau: Beijng, China, 1998; p. 203.

119. Han, Y.M. History of Chinese folk, Sui and Tang Dynasty; People's Publishing House: Beijng, China, 2008 ; p. 142.

120. Li, Y. Common Sense of Folk and Taboo Must Know; The Central Plain Farmer Press: Zhengzhou, China, 2010; p. 119.

121. Zhe, B.F.; Li, S.H.; Hu, X.K. (Eds.) The Ancient Chinese Dictionary; Shenyang Press: Shenyang, China, $2003 ;$ p. 651.

122. Xu, K.; Qing, B.L.; Chao, X. Palace and House.Characteristics of House in Fujian; Zhonghua Book Bureau: Beijng, China, 2003; p. 1231.

123. Macgowan, J. Men and Manners of Modern China; Current Affairs Press: Beijing, China, 1998; p. 300.

124. Sutcliffe, G.L. (Ed.) The Principles and Practice of Modern House-Construction; London: Blackie, London, UK, 1899.

125. Kira, A. The Bathroom: Criteria for Design; Penguin Books: New York, NY, USA, 1976.

126. Wright, L. Clean and Decent-The History of the Bath and Loo and of Sundry Habits, Fashions E Accessories of the Toilet, Principally in Great Britain, France \& America, 2nd ed.; Routledge \& Kegan Paul: London, UK, 1980; pp. 35-51.

127. Cummings, A. The Development of the Flushing Toilet_Detailed Chronology 1596 Onwards; Twyfords Bathrooms: Stoke-on-Trent, UK, 1775.

128. Plunkett, H.M.H. Women, Plumbers, and Doctors: Or, Household Sanitation; D. Appleton and Co.: New York, NY, USA, 1884.

129. Vinnerås, B.; Jönsson, $H$. The performance and potential of faecal separation and urine diversion to recycle plant nutrients in household wastewater. Bioresour. Technol. 2002, 84, 275-282. [CrossRef]

130. Johansson, M.; Jönsson, H.; Höglund, C.; Stintzing, A.R.; Rodhe, L. Urine Separation-Closing the Nutrient Cycle; HSB National Federation: Stockholm, Sweden, 2000.

131. Laureano, P. Water reuse traditional systems. In Urban Water Reuse Handbook; Eslamian, S., Ed.; CRC Press: Boca Raton, FL, USA, 2016; pp. 357-370.

132. Johansson, M.; Jönsson, H.; Höglund, C.; Stintzing, A.; Rodhe, L. Source-Separated Human Urine: A Future Source of Fertilizer for Agriculture in the Stockholm Region?; Stockholm Water Company: Stockholm, Sweden, 2002.

133. Beal, C.; Gardner, T.; Ahmed, W.; Walton, C.; Hamlyn-Harris, D. Closing the Nutrient Loop: A Urine-Separation and Reuse Trial in the Currumbin Ecovillage, qld. On-Site '07 Armidale. 2007. Available online: http://s3.amazonaws.com/publicationslist.org/data/w.ahmed/ref-24/beal-etal-final\%5b1\%5d.pdf (accessed on 3 September 2015).

134. Lienert, J.; Larsen, T. High Acceptance of Urine Source Separation in Seven European Countries: A Review. Environ. Sci. Technol. 2009, 44, 556-566. [CrossRef] [PubMed]

135. Wald, C. The secret history of ancient toilets. Nature 2016, 533, 456-458. [CrossRef] [PubMed]

(C) 2016 by the authors; licensee MDPI, Basel, Switzerland. This article is an open access article distributed under the terms and conditions of the Creative Commons Attribution (CC-BY) license (http://creativecommons.org/licenses/by/4.0/). 